ÉRICA GOMES PEREIRA

\title{
A PARTICIPAÇÃO DA ENFERMAGEM NO TRABALHO EDUCATIVO EM SAÚDE COLETIVA: UM ESTUDO DOS RELATOS DE EXPERIÊNCIA PRODUZIDOS POR ENFERMEIROS BRASILEIROS NO PERÍODO 1988-2003
}

São Paulo 
UNIVERSIDADE DE SÃO PAULO

ESCOLA DE ENFERMAGEM

\title{
A PARTICIPAÇÃO DA ENFERMAGEM NO \\ TRABALHO EDUCATIVO EM SAÚDE COLETIVA: UM ESTUDO DOS RELATOS DE EXPERIÊNCIA \\ PRODUZIDOS POR ENFERMEIROS BRASILEIROS NO PERÍODO 1988-2003
}

\author{
Érica Gomes Pereira \\ Dissertação apresentada à Escola de \\ Enfermagem da Universidade de São Paulo, \\ para obtenção do título Mestre em \\ Enfermagem. \\ Área de concentração: Enfermagem em Saúde \\ Coletiva.
}

Orientadora: Prof ${ }^{\mathrm{a}} \operatorname{Dr}^{\mathrm{a}}$ Cássia Baldini Soares

São Paulo

2005 


\section{Catalogação na publicação (CIP) \\ Biblioteca "Wanda de Aguiar Horta" da EEUSP}

Pereira, Érica Gomes

A participação da enfermagem no trabalho educativo em saúde coletiva: um estudo dos relatos de experiência produzidos por enfermeiros brasileiros no período 1988-2003 / Érica Gomes Pereira. - São Paulo: E. G. Pereira; 2005.

$122 \mathrm{p}$.

Dissertação (Mestrado) - Escola de Enfermagem da Universidade de São Paulo. Orientadora: Prof ${ }^{\mathrm{a}}$. Dr ${ }^{\mathrm{a}}$. Cássia Baldini Soares

1. Educação em saúde 2. Trabalho 3. Enfermagem em saúde pública I. Título. 


\section{Dedicatória}

Aos agentes e sujeitos dos processos educativos 


\section{Agradecimento Especial}

Para a professora doutora Cássia Baldini Soares, orientadora desta pesquisa, que apoiou com grande paciência, perspicácia e empenho o desenvolvimento das minhas potencialidades me fazendo acreditar que o equilibrio entre teoria e prática pode ser possivel. 
Agradecimentos

Aos Professores Doutores Antonio Chizzotti, Anna Maria Chiesa, Eliete Maria Silva e Marina Peduzzi pela valiosa contribuição na banca examinadora.

Às Professoras Doutoras Célia Maria Sivalli Campos e Maria Josefina (Susy)

Leuba Salum, pelos ensinamentos na fase de elaboração da dissertação.

A chefia da Professora Doutora Renata Ferreira Takahashi e a todos os trabalhadores do Departamento de Enfermagem em Saúde Coletiva da Escola de Enfermagem da Universidade de São Paulo

Aos professores, estudantes de graduação, pós-graduação, trabalhadores da rede básica de serviços de saúde e as populações das áreas adscritas das unidades básicas de saúde pelo desafio à reflexão diária acerca do processo de trabalho educativo em saúde.

À Carla Andrea Trapé, por tudo.

Aos meus pais, Jairo e Balbina, e minha irmã, Elen, pelo apoio irrestrito em todos os momentos da minha vida.

E a todas as pessoas que, direta ou indiretamente, contribuíram para a realização deste trabalho. 
Pereira EG. A participação da enfermagem no trabalho educativo em saúde coletiva: um estudo dos relatos de experiência produzidos por enfermeiros brasileiros no período 1988-2003. São Paulo, 2005. 122p. Dissertação (Mestrado) - Escola de Enfermagem. Universidade de São Paulo.

RESUMO: O presente trabalho constituiu-se como um estudo exploratório, valendo-se dos relatos de experiência educativa, de enfermeiros brasileiros, publicados entre 1988 e 2003. A partir das concepções nucleares do campo da saúde coletiva e da educação equacionou um método de identificação dos elementos constituintes do processo de trabalho educativo em saúde. Utilizou como parâmetros na seleção das publicações: trabalhos escritos por enfermeiros, docentes ou não; a descrição de práticas educativas voltadas para uma dada população, realizadas em unidades básicas de saúde ou em instituições sociais do território adscrito. O material foi identificado a partir dos bancos de dados LILACS e PERIENF. Os resultados mostraram que a produção foi assinada especialmente por docentes, do eixo sulsudeste, com a identificação do contexto dos sujeitos fragilmente caracterizada. A responsabilidade pelo "saber fazer" ficou a cargo do docente e dos alunos de pósgraduação e na maioria das vezes o "saber operante" foi assumido pelo aluno de graduação, de pós-graduação ou pelos trabalhadores da rede básica de serviços de saúde. Muitas vezes, as publicações explicitaram as concepções de educação e os instrumentos utilizados no trabalho educativo, mas não os articularam à concepção de saúde norteadora de sua prática social. No entanto, os saberes instrumentais que conformam a concepção de educação em saúde estão na dependência do que os múltiplos agentes do processo de trabalho educativo reconhecem como objeto das práticas sociais em saúde. Assim, é imprescindível empreender esforços para o aprimoramento do processo de elaboração dos relatos identificando o contexto instaurador das necessidades educativas e os elementos teórico-metodológicos que fundamentam as práticas educativas em saúde. Para que o processo de trabalho educativo em saúde instrumentalize as classes/grupos sociais no processo de 
transformação do objeto da saúde coletiva, os perfis epidemiológicos, é necessário mais que clareza e habilidade no uso de recursos pedagógicos. É preciso que a enfermagem como uma das distintas práticas sociais em saúde domine a concepção de saúde e de educação que objetualiza o recorte do objeto do processo de trabalho educativo e a concepção de educação em saúde que aprimora o saber instrumental para a transformação desse mesmo objeto.

Palavras chave: Educação em saúde; Trabalho; Enfermagem em saúde pública. 
Pereira EG. The participation of the nursing in the work of the collective health education: A study of the experience reports produced by brazilian nurses in the period 1988-2003. São Paulo, 2005. 122p. Dissertation (Masters) - School of Nursing. University of São Paulo.

SUMMARY: The present work is constituted as an exploratory study, using itself the stories of the educative experience, of the Brazilian nurses, published between 1988 and 2003. From the nuclear conceptions of the field of collective health and the education a method of identification of the constituent elements of the process of educative work in health was developed. The parameters used in the selection of publications were: works written by nurses, educators or not; the description of the educative practices overturned for a certain population, made in basic units of health or social institutions of the assigned territory. The material was identified from the data banks LILACS and PERIENF. The results show that the production was signed specially by educators, of the axis south-Southeast, with the identification of the context of the subjects fragilely characterized. The responsibility by the "knowledge to $d o^{\prime \prime}$ was responsibility of the professor and of the students of post-graduation and in most of the times the "operating knowledge" was assumed by undergraduate and post-graduation students or by the workers of the basic network of health service. Often, the publications specified the conceptions of education and the instruments used in the educative work, but they did not articulate them to the conception of health that orients its social practice. however, the instrumental knowledge that conform the conception of education in health depends on what the multiple agents of the process of educative work recognize like the object of the social practices in health. Thus, it is essential to undertake efforts for the improvement of the process of elaboration of the reports, identifying the constitutive context of the educative necessities and the theoretical-methodological elements that serve as basis for the educative practices on health. In order to the process of educative work in health 
instrumentalize the classes/social groups in the process of transformation of the object of the collective health, the epidemiologic profiles, it is necessary more than clarity and ability in the use of pedagogical resources. It is necessary that the nursing as one of the distinct social practices in health dominates the conception of health and education that it has as an object crosses the object of the process of educative work and the conception of education in health that perfects the instrumental knowledge for the transformation of that same object.

Keywords: Education in health; Work; Nursing in public health. 
Pereira EG. La participación de la enfermería en el trabajo de la salud colectiva: Un estudio de los relatos de las experiencias producidas por enfermeros brasileros en el período 1988-2003. São Paulo, 2005. 122p. Disertación (Maestría) - Escuela de Enfermería Universidad de São Paulo.

RESUMEN: El presente trabajo se constituye como un estudio exploratorio, valiéndose de los relatos de la experiencia educativa, de los enfermeros brasileros, publicados entre 1988 y 2003. A partir de las concepciones nucleares del campo de la salud colectiva y de la educación se desarrollo un método de identificación de los elementos constituyentes del proceso de trabajo educativo en salud. Se utilizó como parámetros en la selección de las publicaciones: trabajos escritos por enfermeros, docentes o no; la descripción de las prácticas educativas volcadas para una dada población, realizadas en unidades básicas de salud o en instituciones sociales del territorio adscrito. El material fue identificado a partir de los bancos de datos LILACS e PERIENF. Los resultados mostraron que la producción fue firmada especialmente por docentes, del eje sur-sudeste, con la identificación del contexto de los sujetos frágilmente caracterizada. La responsabilidad por el "saber hacer" quedo a cargo del docente y de los alumnos de pos-graduación y en la mayoría de las veces el "saber operante" fue asumido por el alumno de pregrado, de pos-graduación o por los trabajadores de la red básica de servicios de salud. Muchas veces, las publicaciones explicitaron las concepciones de educación y los instrumentos utilizados en el trabajo educativo, pero no los articularon a la concepción de salud que norteaba su práctica social. Aunque, los conocimientos instrumentales que conforman la concepción de educación en salud dependen de lo que los múltiples agentes del proceso de trabajo educativo reconocen como objeto de las prácticas sociales en salud. Así, es imprescindible emprender esfuerzos para el mejoramiento del proceso de elaboración de los relatos identificando el contexto instaurador de las necesidades educativas y de los elementos teórico-metodológicos que fundamentan las prácticas educativas en salud. Para que el proceso de trabajo educativo en salud 
instrumentalice las clases / grupos sociales en el proceso de transformación del objeto de la salud colectiva y los perfiles epidemiológicos, es necesario mas que claridad y habilidad en el uso de recursos pedagógicos. Es necesario que la enfermería como una de las distintas prácticas sociales en salud domine la concepción de salud y de educación que tiene como objeto el recorte del objeto del proceso de trabajo educativo y la concepción de educación en salud que perfecciona el saber instrumental para la transformación de ese mismo objeto.

Palabras clave: Educación en salud; Trabajo; Enfermería en salud pública. 


\section{LISTA DE FIGURAS}

Figura I - Categorias empíricas e indicadores que compõem a descrição geral dos relatos de experiência educativa dos enfermeiros brasileiros

Figura II - Componentes da categoria analítica do processo de trabalho, categorias empíricas e indicadores para captura do processo de trabalho educativo em saúde ...48 Figura III - Agentes da rede básica de serviços de saúde ou relacionadas à educação básica que participaram do planejamento dos temas e/ou da execução do trabalho educativo em saúde

Figura IV - Agentes das universidades que participaram do planejamento dos temas e/ou da execução do trabalho educativo em saúde

Figura V - Adolescentes, pais e professores: temas e âmbito de atuação grupal

Figura VI - Pais, alunos, professores e funcionários: temas e âmbito de atuação grupal

Figura VII - Crianças, familiares e comunidade escolar: temas e âmbito de atuação grupal .64

Figura VIII - Mulheres e mães: temas e âmbito de atuação grupal ..........................65

Figura IX - Adultos: temas e âmbito de atuação grupal..........................................65

Figura X - População em geral, transeuntes e ouvintes de rádio: temas e âmbito de atuação grupal 65

Figura XI - Trabalhadores: temas e âmbito de atuação grupal .67

Figura XII - Elementos constituintes do objeto do processo de trabalho educativo em saúde .85

Figura XIII - Elementos constituintes dos meios/instrumentos do processo de trabalho educativo em saúde .89 Figura XIV - Elementos constituintes da finalidade do processo de trabalho educativo em saúde 93 


\section{LISTA DE TABELAS}

Tabela 1 - Relatos de experiência educativa dos enfermeiros brasileiros, no período 1988-2003 52

Tabela 2 - Relatos de experiência educativa dos enfermeiros brasileiros quanto à região de procedência da atividade educativa, segundo o período 1988-2003 .53

Tabela 3 - Relatos de experiência educativa dos enfermeiros brasileiros quanto à informação sobre o município em que ocorreu a atividade educativa, segundo o período 1988-2003

Tabela 4 - Relatos de experiência educativa dos enfermeiros brasileiros quanto à informação sobre o bairro em que ocorreu a atividade educativa, segundo o período $1988-2003$ 54

Tabela 5 - Relatos de experiência educativa dos enfermeiros brasileiros quanto à informação sobre a comunidade em que se dirigiu a atividade educativa, segundo o período 1988-2003

Tabela 6 - Relatos de experiência educativa dos enfermeiros brasileiros quanto ao tipo de revista em que foi publicada a atividade educativa, segundo o período 19882003.

Tabela 7 - Relatos de experiência educativa dos enfermeiros brasileiros quanto ao local de vínculo e participação dos autores nas publicações, segundo o período 19882003 .56

Tabela 8 - Relatos de experiência educativa dos enfermeiros brasileiros quanto ao caráter da instituição vinculada aos autores das publicações, segundo o período 19882003

Tabela 9 - Relatos de experiência educativa dos enfermeiros brasileiros quanto as necessidades geradoras do trabalho educativo, segundo o período 1988-2003 60 Tabela 10 - Relatos de experiência educativa dos enfermeiros brasileiros quanto a presença das concepções de educação e de saúde constituintes do "saber fazer" do trabalho educativo, segundo o período 1988-2003 
Tabela 11 - Relatos de experiência educativa dos enfermeiros brasileiros quanto a participação dos sujeitos no planejamento dos temas dos trabalhos educativos, segundo o período 1988-2003

Tabela 12 - Relatos de experiência educativa dos enfermeiros brasileiros quanto a identificação do espaço físico em que foi realizado o trabalho educativo, segundo o período 1988-2003

Tabela 13 - Relatos de experiência educativa dos enfermeiros brasileiros quanto ao caráter do local em que foi realizado o trabalho educativo, segundo o período 19882003

Tabela 14 - Relatos de experiência educativa dos enfermeiros brasileiros quanto a freqüência dos encontros do trabalho educativo, segundo o período 1988-2003

Tabela 15 - Relatos de experiência educativa dos enfermeiros brasileiros quanto a presença da concepção de educação em saúde constituinte do "saber operante" dos trabalhos educativos, segundo o período 1988-2003

Tabela 16 - Relatos de experiência educativa dos enfermeiros brasileiros quanto ao tipo de recursos didáticos utilizados nos trabalhos educativos, segundo o período $1988-2003$ 70

Tabela 17 - Relatos de experiência educativa dos enfermeiros brasileiros quanto a freqüência dos encontros do trabalho educativo, segundo o período 1988-2003 .......70 Tabela 18 - Relatos de experiência educativa dos enfermeiros brasileiros quanto a meta a ser alcançada nos trabalhos educativos, segundo o período 1988-2003 71 Tabela 19 - Relatos de experiência educativa dos enfermeiros brasileiros quanto a presença da articulação entre as concepções constituintes do "saber fazer" e do "saber operante" dos trabalhos educativos, segundo o período 1988-2003 .72 Tabela 20 - Relatos de experiência educativa dos enfermeiros brasileiros quanto a identificação dos avaliados dos trabalhos educativos, segundo o período 1988-2003 


\section{SUMÁRIO}

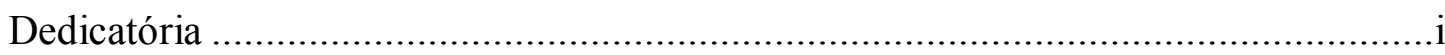

Agradecimento Especial.............................................................................. ii

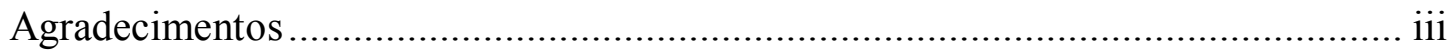

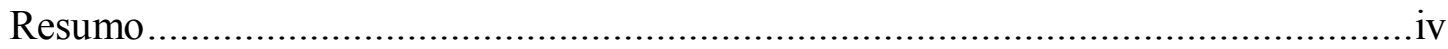

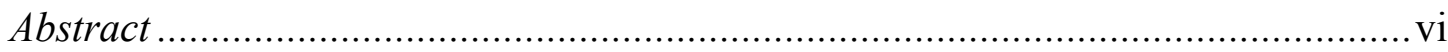

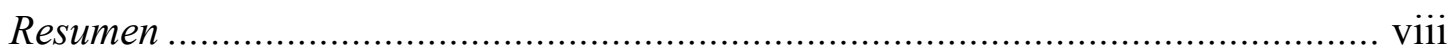

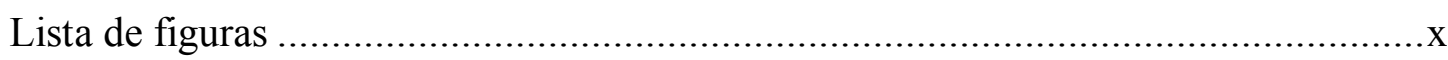

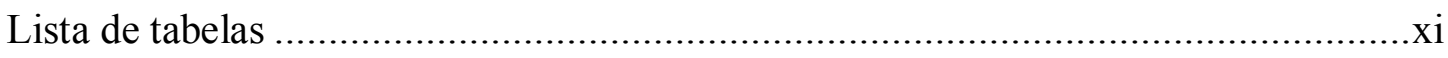

1 INTRODUÇÃO: O OBJETO E O PROBLEMA DE ESTUDO.............................15

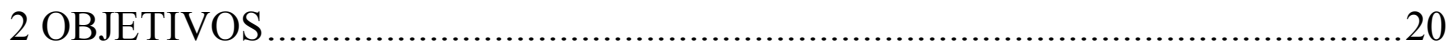

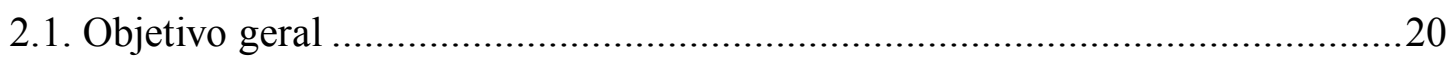

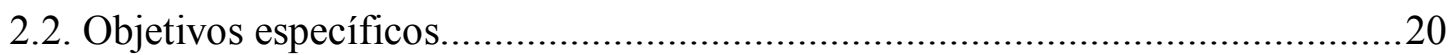

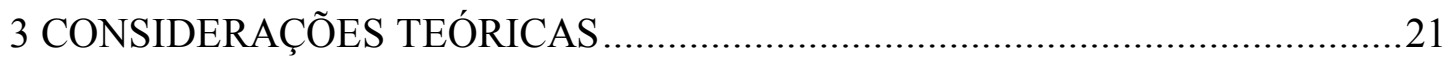

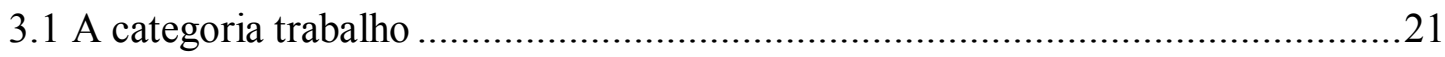

$3.2 \mathrm{O}$ processo de trabalho em saúde ..............................................................27

$3.3 \mathrm{O}$ trabalho da enfermagem em saúde coletiva ...............................................31

3.4 O processo de trabalho educativo em saúde.....................................................34

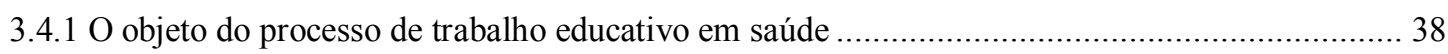

3.4.2 Os meios e instrumentos do processo de trabalho educativo em saúde ................................ 41

3.4.3 A finalidade do processo de trabalho educativo em saúde........................................... 42

4 PROCEDIMENTOS METODOLÓGICOS ......................................................45

4.1 $\mathrm{O}$ instrumento de coleta de dados e as categorias empíricas .............................46

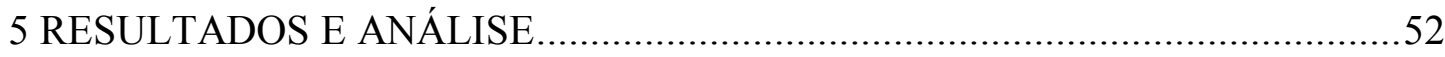

5.1 Caracterização dos relatos de experiência educativa dos enfermeiros brasileiros na rede básica de serviços de saúde ....................................................................52

5.2 Descrição dos elementos constituintes do trabalho educativo em saúde a partir dos relatos de experiência educativa dos enfermeiros brasileiros na rede básica de

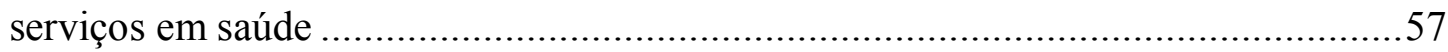

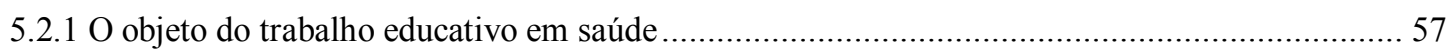


5.2.3 A finalidade do trabalho educativo em saúde …………......................................................... 70

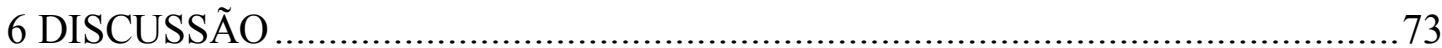

6.1 Caracterização geral dos relatos de experiência educativa dos enfermeiros

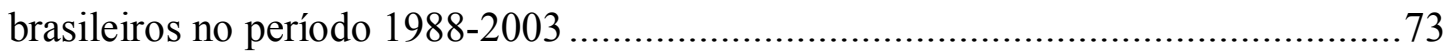

6.2 Elementos constituintes do processo de trabalho educativo em saúde .................74

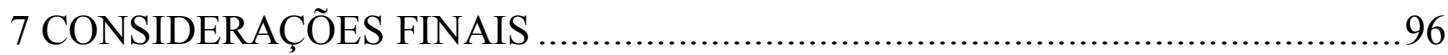

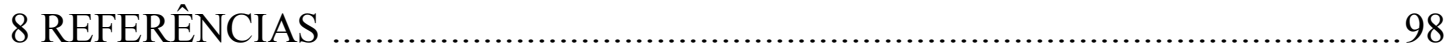

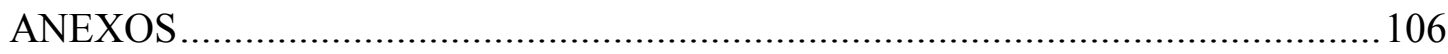

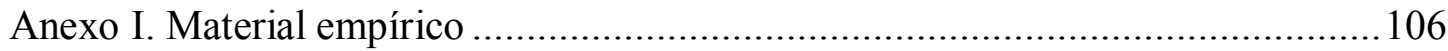

Anexo II. Instrumento de coleta de dados.......................................................... 112

Anexo III. Objeto, sujeito, tema, âmbito de atuação grupal e meta a ser alcançada/finalidade dos relatos de experiência educativa produzidos por enfermeiros brasileiros no período 1988-2003

Anexo IV. Meta a ser alcançada/finalidade apreendida a partir do material empírico 


\section{INTRODUÇÃO: O OBJETO E O PROBLEMA DE ESTUDO}

O objeto de estudo deste trabalho é o processo educativo em saúde conformado como uma das atividades inscritas na prática social da enfermagem ao integrar o processo de trabalho em saúde.

As pesquisas que tomam como objeto a educação em saúde têm predominantemente procurado compreender a tarefa educativa como parte da superestrutura jurídico-política e ideológica que sustenta o trabalho em saúde, mas poucos (Gonzaga, 1992a; Gonzaga, 1992b; Silva, Gonzaga e Verdi, 1992) relacionam trabalho em saúde e processo de trabalho educativo em saúde.

Quando a tarefa educativa é tomada como um processo específico do trabalho em saúde, a partir da prática social da enfermagem, de acordo com Gonzaga (1992a), é necessária a incorporação de elementos que constituirão o objeto, os instrumentos, as necessidades geradoras para o trabalho e as finalidades de trabalho.

A autora salienta que, no cotidiano das práticas educativas em saúde, se explicita um objeto que é tomado sob o olhar da clínica ou da epidemiologia. Valendo-se de saberes e instrumentos reproduzidos e incorporados à atividade de modo alienado, ou seja, desintegrados da reflexão sobre sua potencialidade para a transformação do objeto. Caminhando nessa direção, a aplicação do instrumento se torna a finalidade do trabalho e o trabalhador se torna um mero aplicador do método; este, por sua vez tem uma existência per si, sem que sejam explicitadas as visões de mundo que estão embutidas no objeto (Gonzaga, 1992a).

$\mathrm{Na}$ avaliação de Lobo (1987), que ao relatar uma experiência educativa comunitária, chama a atenção para práticas de pesquisa que se instituem sob o manto de uma concepção que serve ao propósito de bloquear a participação popular nas decisões fundamentais da sociedade, ainda que tal ação viesse escondida sob a forma de temor do povo, fazer pelo povo que ainda não está preparado para dirigir-se por si mesmo. Na esfera educativa, do mesmo modo, vem acontecendo diante dessa prática instaurada a partir do modelo biomédico hegemônico que a população tem corrido o risco de ficar apenas na constatação dos problemas e os trabalhadores da saúde têm se limitado a uma pedagogia de doação de si mesmos e de seu tempo disponível, omitindo-se da intervenção e troca de conhecimento. Por exemplo, não 
há incentivo às ações dos moradores em busca de soluções para seus problemas. Dessa forma, fica-se apenas na aparência, não ocorrendo incursão às causas e, sem que se procure, portanto à sua essência.

E é assim que Queiroz e Salum (2000:27), consideram que a enfermagem tem servido majoritariamente ao projeto de

educação para a saúde, [que no discurso se diz] (...) potencialmente transformador da realidade de saúde, mas que na verdade percorre um trajeto em que, sob uma ótica, veicula um receituário universal para se adquirir saúde; sob outra ótica transfere um saber técnico, a título de compartilha, mas que de fato responsabiliza o usuário dos serviços pelo auto-cuidado e, simultaneamente, desresponsabiliza o serviço de saúde pela saúde de quem é educado.

E pelo que até aqui foi considerado, reafirma-se a concepção de que a Enfermagem, bem como as outras práticas sociais em saúde com que estabelece relações, evidencia sua subordinação ao projeto político que suporta o modo de produção vigente na constituição de seus trabalhadores, nos conteúdos técnicocientíficos, nos processos de trabalho que realiza e, particularmente, no objeto para o qual se dirige (Salum, Bertolozzi e Oliveira, 1999).

Neste trabalho, parte-se do entendimento então de que, sendo o processo educativo em saúde um dos instrumentos da prática social da enfermagem, a fundamentação teórica da assistência de enfermagem que recupera a articulação educação-cidadania deveria incluir os conceitos de homem, sociedade, processo saúde-doença, sistemas de saúde, enfermagem, educação, participação, práxis e cidadania (Silva et al, 1992). Nesse sentido, a mediação, a redescoberta do sujeito e o resgate da práxis como objeto e finalidade das ações educativas tornam-se fundamentais para a construção de um referencial que supere seus estereótipos e suas contradições (Gonzaga, 1992b).

Os passos para a implementação do processo educativo em saúde a fim de potencializar a conquista da cidadania dos grupos sociais, compreenderão (Gonzaga, 1992b):

1) O conhecimento da realidade concreta que traz em si a práxis cotidiana da comunidade, 
2) O planejamento grupal das ações educativas sem a centralidade de poder decisório do educativa e com a participação da população,

3) A ação no plano imediato, seja individual, familiar, grupal ou coletivo, articulado a um processo crítico de percepção da realidade para a mobilização da ação,

4) O questionamento crítico da realidade acerca dos seus determinantes e das estratégias para sua superação,

5) A síntese dos conhecimentos e experiências vivenciadas para uma práxis crítica e criativa que supera a visão fragmentária da realidade.

Dada a complexidade do objeto ao qual se dirige o processo educativo em saúde é preciso reconhecer que

\begin{abstract}
a Enfermagem só se defrontou com a noção de coletivo no início do século $X X$, quando a prática médica tomou para si o discurso da promoção e da recuperação da saúde, configurado no modelo de educação sanitária. Isso decorreu da necessidade de ampliar as margens de consenso entre as classes frente às pressões dos movimentos reivindicatórios dos trabalhadores, conseqüencia das crises geradas pela Primeira Grande Guerra (Salum, Bertolozzi e Oliveira, 1999:108)
\end{abstract}

Foi somente, porém, com o movimento da Reforma Sanitária dos anos 70 e com a constituição do campo da Saúde Coletiva, que a Educação em Saúde passou a sofrer influência de autores, como Paulo Freire, que preconizaram o caráter emancipatório da educação. De fato, as experiências na saúde em geral (Merhy, 1987) e na enfermagem em particular (Germano, 1983; Melo, 1986; Silva, 1986) testemunham o desenvolvimento de práticas educativas populares consideradas progressistas e potencialmente transformadoras da situação de saúde.

Nesse sentido, UIPES ${ }^{1}$ (1998), ao relatar o conteúdo discutido num seminário nacional sobre a formação de recursos humanos para a área da educação em saúde,

\footnotetext{
${ }^{1}$ A União Internacional de Promoção da Saúde e Educação Para a Saúde é uma associação criada em 1951 que congrega uma rede mundial de pessoas e instituições para promover o avanço do conhecimento e melhorar a efetividade da Promoção da Saúde e da Educação para a Saúde em estreita cooperação com a OMS, UNESCO e UNICEF. A Representação da Sub-região Brasil constituída em 1993, esforça-se para se tornar um pólo receptor e irradiador da Promoção da Saúde/Educação em
} 
chama a atenção para aquilo que o Conselho Nacional de Saúde (CNS), em sua resolução $n^{\circ} 41$ de 03/03/93 reafirma

deve ser a educação para a saúde considerada estratégia imprescindivel para a promoção da saúde, prevenção das doenças e para a consolidação do SUS, nos níveis federal, estadual e municipal. Esta resolução do CNS é referendada pelo Ministério da Saúde, no Documento Final da Proposta de Reforma Administrativa (Grupo Executivo para a Reforma Administrativa - GERAS, 1993), que considera a Educação em Saúde como um dos espaços de intervenção estratégica para a política de saúde. É ainda, considerada como área que perpassa toda a estrutura organizacional dos serviços, articulando-se com a informação, a comunicação, e a epidemiologia, corroborando-se em estratégia básica para a consolidação do sistema.

O pressuposto deste trabalho é o de que, após a promulgação da Constituição Federal que legitimou a saúde como direito de todos e dever do Estado, - com a conseqüente regulamentação do Sistema Único de Saúde (SUS), das mudanças nos modelos assistenciais e a recente constituição do campo da Saúde Coletiva -, a educação em saúde tenha se transformado, sob a influência dos marcos teóricometodológicos e operacionais que fundamentaram a constituição do SUS, passando pelas bases da rede básica de serviços de saúde e do campo da Saúde Coletiva. Ou seja, a suposição é a de que a ação educativa caminhou rumo a uma transformação do olhar sobre o objeto, valendo-se de instrumentos que possibilitaram o redimensionamento de sua finalidade, a partir de perspectivas teórico-metodológicas que promoveram rupturas com aquelas que sustentavam as práticas até então reiterativas do modelo médico hegemônico.

O conjunto problematizador deste estudo pode ser sintetizado através das seguintes perguntas: A enfermagem está realizando práticas educativas na rede básica de serviços em saúde? Quais os processos de trabalho do processo de

Saúde no Brasil e na América Latina. São membros latino-americanos do Conselho de Administração da UIPES: Márcia Faria Westphal (Brasil), Helena Restrepo (Colômbia), Dora Cardaci (México), Juan Manuel Castro (México) e Hiran Arroyo Acezedo (Puerto Rico). 
produção de serviços de saúde, cujos agentes envolvem a enfermagem, que utilizam o instrumento educativo? O SUS estaria alicerçando o desenvolvimento de práticas em educação em saúde? Quais são as características dos elementos do processo educativo na rede básica de serviços em saúde? Quais são as implicações para o campo da Saúde Coletiva? 


\section{OBJETIVOS}

\subsection{Objetivo geral}

- Investigar a produção científica expressa nos relatos de experiência da enfermagem sobre a prática de educação em saúde na rede básica de serviços em saúde.

\subsection{Objetivos específicos}

- Caracterizar a contribuição da produção científica expressa nos relatos de experiência educativa da enfermagem na rede básica de serviços em saúde para a consolidação da prática de educação em saúde no SUS;

- Reconhecer na produção científica expressa nos relatos de experiência educativa da enfermagem os elementos do processo de trabalho educativo realizado na rede básica de serviços em saúde;

- Identificar na produção científica expressa nos relatos de experiência educativa da enfermagem o tipo de saber implicado na educação em saúde praticada na rede básica de serviços em saúde. 


\section{CONSIDERAÇÕES TEÓRICAS}

\subsection{A categoria trabalho}

O desenvolvimento da vida social, política e intelectual é condicionado pelo modo de produção da vida material (Marx, 1977). Nesse sentido, a compreensão da prática social da enfermagem enquanto trabalho tende a possibilitar a proposição de estudos e ações de intervenção na utilização de ferramentas que potencializam o "trabalho vivo" em ato, a fim de propiciar satisfação, autonomia e emancipação dos trabalhadores e dos usuários para uma assistência qualificada de saúde (Almeida, Mishima e Peduzzi, 1999).

Como profissão, de acordo com Castellanos (1988), a enfermagem responde a específicos valores sociais e sua capacidade de intervir na situação de assistência à saúde estará na dependência direta do grau de conhecimento que ela tem desta situação, a par de sua competência técnico-científica.

Os distintos processos de trabalho em saúde subordinam-se ao processo de produção dos serviços de saúde. A especificidade da enfermagem, enquanto prática social na área da saúde dá-se, portanto, pelos saberes e tecnologias que lhe são próprios (Queiroz e Salum, 1996).

Não há como negar a qualificação das práticas sociais em saúde, e especificamente a de enfermagem, como trabalho. Desde a publicação do ensaio pioneiro de García (1983), passando pela contribuição inegável de Mendes Gonçalves (1979, 1992, 1994), um conjunto de pesquisadores em enfermagem ocupou-se de examiná-la sob a perspectiva marxista, fosse analisando o cuidado como sua especificidade (Nakamae 1987; Almeida e Rocha 1997), fosse buscando reconhecer os elementos fundamentais do processo de trabalho na prática do enfermeiro e dos demais trabalhadores que compõem a força de trabalho na enfermagem (Castellanos, 1989; Queiroz e Salum, 1997; entre outros).

Assim sendo, o presente estudo considera o trabalho como a categoria central de análise para a compreensão das relações sociais de produção contraditórias e, ao mesmo tempo potencialmente transformadoras, ocorridas, especificamente, no desenvolvimento dos processos de trabalho educativos em saúde. 
Nessa perspectiva, o trabalho é entendido como uma relação entre o homem e a natureza,

em que o ser humano com sua própria ação, impulsiona, regula e controla seu intercâmbio material. Põe em movimento as forças naturais de seu corpo, braços e pernas, cabeça e mãos, a fim de apropriar-se dos recursos da natureza, imprimindo-lhes forma útil à vida humana. Atuando assim sobre a natureza externa e modificandoa, ao mesmo tempo modifica sua própria natureza. Desenvolve as potencialidades nela adormecidas e submete ao seu domínio o jogo das forças naturais (Marx, 1968:202).

Dessa maneira, quando o homem esquadrinha na sua mente a transformação de um ponto específico da natureza para satisfazer suas necessidades, o faz por meio de um processo de objetivação, a transposição para o mundo concreto de uma idéia previamente estabelecida - subjetiva - sobre o que espera transformar na própria natureza a fim de satisfazer essas necessidades (Mendes Gonçalves, 1992; Lessa, 1996).

Por isso, o processo de objetivação do homem em relação com a natureza transforma a prévia ideação, isto é, a finalidade previamente construída na consciência do homem, em um produto objetivo, concreto. A partir da ontologia lukacsiana se reitera a máxima marxista de que, ao transformar a natureza, o ser humano também se transforma porque desenvolve novas habilidades e, para poder vencer a resistência que se opõe à sua transformação em objetos construídos pelos homens, torna-se necessário o conhecimento dos nexos causais e das determinações do setor da natureza que deseja transformar. Assim, sempre resultará em novos conhecimentos e habilidades e, portanto, ao transformar a natureza o indivíduo também se transforma (Lessa, 1996).

O fato é que se parte do pressuposto de que o trabalho é uma característica essencialmente humana e que marca sua distinção com as demais espécies. A alegoria de Marx traduz essa concepção quando o autor considera que:

o que distingue o pior arquiteto da melhor abelha é que ele figura na mente sua construção antes de transformá-la em realidade. No fim do 
processo do trabalho aparece um resultado que já existia antes idealmente na imaginação do trabalhador. Ele não transforma apenas o material sobre o qual opera; ele imprime ao material o projeto que tinha conscientemente em mira, o qual constitui a lei determinante do seu modo de operar e a qual tem de subordinar sua vontade. E essa subordinação não é um ato fortuito. Além do esforço dos órgãos que trabalham, é mister a vontade adequada que se manifesta através da atenção durante todo o curso do trabalho Marx (1968:202).

Ao tomar a teoria marxista como ponto de partida, Althusser (1999:45), relaciona como elemento constitutivo do trabalho humano:

uma seqüência de operações sistematicamente reguladas, efetuadas pelos agentes do processo de trabalho que "trabalham" um objeto de trabalho (matéria bruta, matéria prima, animais domésticos, etc), empregando para tal fim instrumentos de trabalho (ferramentas mais ou menos elaboradas, em seguida, máquinas, etc) de maneira a "transformar" o objeto de trabalho, por um lado, em produtos próprios a satisfazerem as necessidades humanas diretas (alimentação, vestuário, moradia, etc) e, por outro, em instrumentos de trabalho destinados a garantir a prossecução ulterior do processo de trabalho.

As considerações de Althusser traduzem aquilo que se reconhece como “mediações de primeira ordem” na relação homem-natureza e que, segundo Antunes (2000), fundamentado na estruturação teórica de István Mészàros, dota o trabalho da finalidade de preservar as funções vitais da reprodução individual e social na satisfação das necessidades humanas.

Para Marx (1968), a mercadoria, isoladamente considerada, é a célula elementar da riqueza nas sociedades regidas pelo modo de produção capitalista e o objeto externo é o que satisfará as necessidades humanas, seja como meio de subsistência ou, meio de produção. 
Ainda para o autor, qualquer coisa útil pode ser caracterizada sob duplo aspecto, conforme sua qualidade e quantidade. Por exemplo, a utilidade da borracha faz dela um valor de uso. Ao ser considerado valor de uso, sempre implicará uma quantidade definida, por exemplo, dez borrachas, cem borrachas, etc. O valor de uso da borracha só se realizará com o seu consumo e/ou utilização.

O valor de troca passará a existir na relação entre valores-de-uso de espécies diferentes, na proporção em que se trocam e mudam constantemente no tempo e no espaço. As mercadorias, como valores de uso são heterogêneas na qualidade/utilidade, mas como valores-de-troca só podem diferir na quantidade (Marx, 1968).

Por exemplo, a borracha se troca por outras mercadorias, nas mais diversas proporções, dez borrachas por um lápis, ou por três apontadores ou por uma caneta, etc. Todavia, como cada uma das mercadorias separadamente é o valor de troca das dez borrachas, devem $\mathrm{X}$ lápis, $\mathrm{Y}$ apontadores ou $\mathrm{W}$ canetas serem permutáveis e iguais entre si. Por isso, os valores de troca de uma mesma mercadoria expressam todos uma conformação igualitária e a maneira como se expressam revela um conteúdo que por meio deles se pode distinguir (Marx, 1968).

Ao trocar a borracha por outra mercadoria de qualidade/utilidade diferente, como por exemplo, a caneta, ficam de lado seus valores de uso quando estão na proporção adequada para a troca; prescindindo seu valor de uso só lhes restará uma propriedade, a de serem produtos do trabalho. Ao prescindir do caráter útil dos produtos do trabalho, também desaparecerá o caráter útil dos trabalhos neles corporificados e as diferentes formas de trabalho concreto serão reduzidas a uma única espécie de trabalho, o trabalho humano abstrato (Marx, 1968:44).

Dessa maneira, o valor de uma mercadoria só pode ser quantificado por meio da quantidade da "substância criadora de valor" que é o trabalho humano abstrato, o que faz com que a grandeza do valor seja determinada pela quantidade de trabalho socialmente necessário para a produção de um valor de uso. Assim, por exemplo, o ar pode ser valor de uso sem ser valor porque sua utilidade para o ser humano não decorre de um trabalho. Uma coisa para se tornar mercadoria precisa não apenas produzir um valor de uso, mas produzir valor de uso para outros dando origem ao valor de uso social que variará na razão direta da quantidade e na inversa da produtividade do trabalho aplicado (Marx, 1968). 
Segundo Rubin (1987), o valor é uma relação homem-homem que assume uma forma material - a mercadoria - e está relacionado ao processo de produção tempo de trabalho socialmente necessário para produzir o produto.

Para o autor, na teoria de Marx sobre o valor, a transformação do trabalho privado em trabalho social só pode realizar-se por meio da transformação do trabalho concreto em trabalho abstrato. Para tanto, essa transformação não é uma categoria fisiológica, mas uma categoria social e histórica. A expressão teórica desse fato social, qual seja, a igualação social das diferentes formas de trabalho - e não sua igualdade fisiológica - é que constitui a categoria trabalho abstrato.

Os economistas clássicos, de acordo com Rubin (1987), ao sustentarem que o trabalho é a medida real do valor de troca de todas as classes de bens, estão afirmando que o trabalho é, na verdade, o conteúdo natural das relações sociais fundadas na troca. Marx, ao contrário dos clássicos, não toma o valor como a essência da naturalidade da sociedade, mas sim como a expressão de uma sociedade em que o indivíduo só existe enquanto produtor de valor de troca, o que implica a negação absoluta de sua existência natural. Assim, a produção de valor de troca já inclui em si um ato coercitivo. A atividade particular de cada produtor só adquire sentido quando sancionada pela forma geral do valor de troca, isto é, pelo dinheiro. A mercadoria só se confirma como valor no momento em que se transforma em mercadoria geral, em dinheiro, e o trabalho concreto (técnico-material) de cada ser humano só é validado como trabalho social quando seu produto é acolhido pelo dinheiro como representante do trabalho em geral.

Por isso, Antunes (2000) afirma que a completa subordinação das necessidades humanas à reprodução do valor de troca - no interesse da autorealização expansiva do capital - constituiu a emergência de "mediações de segunda ordem" com a natureza. Uma vez que, para converter a produção do capital em propósito da humanidade, ocorreu a separação entre seu valor de uso e valor de troca, subordinando o primeiro ao segundo, a relação do homem com a natureza ficou subordinada à relação homem-homem para a satisfação das necessidades humanas.

Na sociedade mercantil-capitalista,

o capitalista, o trabalhador assalariado e o proprietário de terra são possuidores de mercadorias, formalmente independentes um do outro. O capitalista tem de comprar do trabalhador o direito de utilizar sua 
força de trabalho, e, do proprietário de terra, o direito de utilizar sua

terra. Para fazê-lo, tem de possuir capital suficiente (Rubin, 1987).

Nesse sentido, a subsunção formal existirá na medida em que a forma social determinante na produção da vida material/concreta é a venda pelo trabalhador da propriedade de sua capacidade e/ou força para o trabalho a fim de comprar os meios necessários para a subsistência. Assim, a propriedade da força de trabalho passará a pertencer ao capitalista - proprietário dos meios de produção que a consumirá, fazendo o vendedor dela trabalhar. O trabalhador irá incorporar trabalho humano ao transformar a matéria, objeto do seu trabalho, e valor além do necessário para sua reprodução social. O produto do seu trabalho será, portanto, alienado porque não pertencerá ao trabalhador, mas sim ao capitalista que prolongará o tempo de trabalho para produzir valor além do necessário, a fim de extrair a mais valia (Marx, 1968; Rubin, 1987).

O desenvolvimento da tecnologia no decorrer do século $\mathrm{XX}$ possibilitou a divisão pormenorizada do trabalho, ou seja, o trabalhador tornou-se especialista numa pequena parte do seu processo de trabalho e é nesse momento que aparece a subsunção real (Antunes, 2000).

O trabalhador, detentor do "trabalho vivo" - que acrescenta valor à mercadoria -, se torna mediador da tecnologia do "trabalho morto" - que já possui armazenado em si mesmo o trabalho humano. As relações de produção se coisificam já que a relação homem-homem estabelecida na mediação de segunda ordem subordina a relação ontológica com a natureza para a satisfação de suas necessidades. Assim, só há relação entre os produtores de mercadorias para sua troca material e as mercadorias, por sua vez, se personificam tomando emprestadas características humanas já que se trocam mutuamente e a relação homem-homem contida no valor de troca fica subsumida nesse processo de "fetichização" (Marx, 1968; Rubin, 1987).

Nesse sentido, o trabalhador, que diretamente produzir mais valia, gerará por meio da venda do seu trabalho produtivo a valorização do processo capitalista de produção. Para Marx (1978:75),

o que constitui o valor de uso específico [do trabalho produtivo] para o capital não é seu caráter útil determinado, como tampouco as 
qualidades úteis peculiares ao produto no qual se objetiva, mas seu caráter de elemento criador de valor de troca (mais-valia).

Por isso, um trabalho de conteúdo semelhante pode ser produtivo ou improdutivo e a diferença estará no fato de o trabalho trocar-se por dinheiro como dinheiro ou por dinheiro como capital (Marx, 1978).

\subsection{O processo de trabalho em saúde}

O trabalho em saúde se localiza no setor terciário da produção capitalista - o campo do trabalho em serviços - e se diferencia da produção material industrial e do trabalho no setor primário da economia, desde a emergência do modo de produção capitalista (Pires, 1998).

Sob a análise marxista, o trabalho em saúde se define como um conjunto de práticas sociais e saberes específicos que se realizam em sua relação com a totalidade social e com cada uma das instâncias que a integram e que consistem em uma infraestrutura econômica composta de forças produtivas e relações de produção, e uma superestrutura que compreende as instâncias jurídicas, políticas e ideológicas (García, 1983).

Os elementos constitutivos do processo de trabalho em saúde foram inicialmente apontados por Mendes Gonçalves (1979, 1992, 1994), que se valeu da produção teórica de Marx para decodificar os elementos do processo de trabalho em saúde, estudando primeiramente o trabalho médico em sua dissertação de mestrado e, em seguida, quando apresentou sua tese de doutoramento sobre a avaliação da organização tecnológica das práticas sociais em saúde.

Segundo Mendes Gonçalves (1992), na sociedade comunitária primitiva o principal agente do processo de trabalho em saúde era o xamã. Sua concepção de "doença" e, conseqüentemente, seu objeto de trabalho - uma entidade que se apossa de um indivíduo, ou que se agrega a ele, fazendo-o sofrer - seriam responsáveis pela realização de rituais religiosos com a finalidade de atingir e expulsar a entidadedoença. Assim, boa parte dos seus instrumentos de trabalho teriam qualidades imediatamente rituais; porém, ao se valer de uma planta como parte de seu trabalho, não seria de se supor que estaria fazendo uso das propriedades farmacológicas da 
mesma. Perceba-se que é das propriedades rituais de que ele teria se valido, pois são as únicas que fazem sentido. Eventualmente, uma importância apenas secundária seria atribuída ao fato de que esse "doente" se "curasse", conforme os padrões contemporâneos de julgamento sobre o que é "curar-se".

$\mathrm{Na}$ avaliação do autor, durante toda a história das sociedades ocidentais, até há cerca de dois séculos, os objetos dos processos de trabalho em saúde sempre foram então representados por "entidades". Um único período importante constituiuse exceção, e por isso, quando a medicina moderna se descortinou como prática social, a partir do fim do século XVIII, tendeu a buscar na Grécia clássica seus símbolos (Mendes Gonçalves, 1992).

Assim, foi que a medicina hipocrática empreendeu uma classificação, pela observação do rol de alterações naturais que fazem o homem sofrer, chamando a esse processo "clínica". A finalidade do trabalho médico passou a ser o de imitar e favorecer a natureza a encontrar o caminho do esforço bem sucedido, ou mesmo, evitar seus fracassos, transformando um esforço mal-sucedido em seu oposto. $\mathrm{O}$ ato de reconhecer o tipo de desequilíbrio presente passou a chamar-se "diagnóstico" e o de saber para onde o conjunto de processos de reequilíbrio se encaminhava designouse como "prognóstico" (Mendes Gonçalves, 1992).

Essa estrutura, assim reconhecida, legitimou daí por diante o trabalho médico e, por conseguinte, a produção de serviços de saúde, nele centralizada. Tomando como foco a doença e a doença do indivíduo preencheu a literatura especializada e, por conseqüência, as práticas de intervenção em saúde.

Recuperando os autores que se confrontaram com essa concepção Laurell e Noriega (1989) trazem à baila a articulação entre o processo social e o processo de saúde e doença que, para os autores, assume características heterogêneas conforme o modo como cada grupo social se insere na produção da vida material e se relaciona com os outros grupos sociais constitutivos da sociedade.

Desse modo, o caráter social do processo saúde-doença advogado pela medicina social se manifestará empiricamente com mais clareza na coletividade do que no indivíduo. Assim, ao reconhecer o processo saúde-doença coletivo interessa saber como o processo biológico ocorre socialmente readquirindo então a unidade entre "a doença" e "a saúde", dicotomizada no pensamento médico clínico. Isso ocorre porque, visto como processo da coletividade, o preponderante é o modo 
biológico de viver em sociedade, que expressará, por sua vez, os transtornos biológicos característicos, isto é, a doença que não aparecerá separada daquele: ambos ocorrem como momentos de um mesmo processo, porém, diferenciáveis (Laurell, 1983).

A unidade básica de saúde, de acordo com Schraiber e Mendes Gonçalves (2000), é destinada para uma estratificação especial de usuários, isto é, para as pessoas que se dirigem aos serviços pela primeira vez. Não se trata de uma primeira vez na vida pessoal, mas na ocorrência mórbida por algum tipo de sofrimento. Por isso, os autores definem como uma atenção primeira e básica, simultaneamente, já que por ser o primeiro atendimento, servirá obrigatoriamente como porta de entrada para o sistema de assistência à saúde. No sistema, desencadeará um nível específico de atendimento que resolverá uma série de necessidades que extrapolam a intervenção curativa individual.

Nesse sentido, de acordo com os autores, caberá à educação em saúde a transformação das necessidades "não sentidas", definidas como necessidades potenciais na linguagem sistêmica - dos sistemas de saúde, em necessidades reconhecidas como pertinentes a um cuidado básico e inicial, isto é, necessidades "sentidas" pela população e tecnologicamente apropriadas para uma 'atenção primária".

Na América Latina, a reforma do setor saúde, empreendida a partir do início da década de 1980, tenta incorporar na rede básica de serviços de saúde, as conquistas democráticas alcançadas pelos povos latino-americanos e caribenhos como resposta à crise da saúde pública tradicional provocada pela centralidade do trabalho médico na produção de serviços de saúde, todavia como muitas das reformas são apoiadas por organismos financeiros internacionais, há muita divergência em relação aos projetos originais da reforma sanitária. E é assim que, a democratização da rede básica de serviços de saúde ainda não proporciona $a$ publicização (isto é: controle público das políticas e práticas institucionais dos respectivos Estados) dos seus aparelhos e mesmo de suas burocracias (Paim e Almeida Filho, 1998:306).

Para Breilh (1995:29),

la salud pública convencional conceptualiza la salud-enfermedad empíricamente, reduciéndola al plano fenomênico e individualizado 
de la causalidad etiológica, la salud colectiva plante ala determinación histórica del proceso colectivo de producción de estados de salud-enfermedad. Mientras la salud pública acoge los métodos empírico-analítico (estructural funcionalista), popperiano o fenomenológico, la salud colectiva incorpora el método materialista dialéctico. Mientras la salud pública centra su acción desde la óptica del Estado com los intereses que este representa em la sociedades capitalistas, la salud colectiva se enfoca como recurso de la lucha popular y la crítica-renovación estratégica del quehacer estatal. Mientras la salud pública assume la actitud posibilista del logro de mejoras puntuales y graduales, la salud colectiva plante ala necesidad de uma acción para el cambio radical.

Do mesmo modo, o modelo da determinação social do processo saúde doença para Victora, Facchini, Barros e Lombardi (1990:303),

propõe que, dado um determinado modo de produção, situa-se um processo de reprodução social que se concretiza em uma dada formação social. Essa formação determina a existência de uma estrutura de classes sociais e suas relações. A dinâmica de classe implica em uma relação unitária entre produção e consumo; nesta dialética, a produção não ocorre na ausência do consumo, e o consumo depende da produção. A determinação do processo biopsicossocial coletivo nas diferentes classes sociais é mediado, assim, pelos processos de produção e de consumo. No tocante à produção, a inserção dos agentes sociais em processos concretos de trabalho determina não somente sua própria exposição a riscos ocupacionais específicos como também seu acesso à riqueza ali produzida, através de seus rendimentos. Esses rendimentos, por sua vez, determinam os níveis de consumo e, portanto, o acesso a bens materiais de vida que incluem, entre outros, alimentação, moradia, saneamento, assistência médica, escolaridade, etc. Assim, através da dialética produção-consumo, é possível entender os diferenciais de saúde entre os grupos sociais e dentro de cada grupo. 
Assim sendo, o marco conceitual da saúde coletiva permite uma delimitação compreensivelmente provisória desse campo científico, enquanto campo de conhecimento e âmbito de práticas (Paim e Almeida Filho,1998:309).

Para Paim e Almeida Filho (1998:309), como campo de conhecimento a saúde coletiva propõe

o estudo do fenômeno saúde/doença em populações enquanto processo social; investiga a produção e a distribuição das doenças na sociedade como processos de produção e reprodução social; analisa as práticas de saúde (processo de trabalho) na sua articulação com as demais práticas sociais; procura compreender, enfim, as formas com que a sociedade identifica suas necessidades e problemas de saúde, busca sua explicação e se organiza para enfrentá-los.

E ainda como âmbito de práticas, a saúde coletiva

envolve determinadas práticas que tomam como objeto as necessidades sociais de saúde, como instrumentos de trabalho distintos saberes, disciplinas, tecnologias materiais e não materiais, e como atividades intervenções centradas nos grupos sociais e no ambiente, independentemente do tipo de profissional e do modelo de institucionalização (Paim e Almeida Filho, 1998:309).

\subsection{O trabalho da enfermagem em saúde coletiva}

Peduzzi (2001), ao sintetizar as diferentes abordagens sobre o trabalho da enfermagem, aponta a existência de duas correntes distintas: uma que percebe os processos de trabalho da enfermagem como referidos ao processo de produção em saúde, tendo portanto a enfermagem o mesmo objeto das outras práticas sociais em saúde e instrumentos específicos; e outra que considera as especificidades dos elementos que compõem o processo de trabalho de enfermagem, tendo, portanto, não só instrumentos próprios, mas também objeto e finalidade específicos. 
A análise macro-estrutural das determinações sociais de produção é ressaltada na vertente teórica do materialismo histórico e na matriz metodológica da dialética. Os estudos acerca do processo de produção em saúde e do trabalho da enfermagem proporcionaram micro-análises da enfermagem na formação social capitalista, particularmente de sua constituição e evolução histórica na sociedade brasileira, delineando uma compreensão dessa prática na sua dimensão histórica e social (Almeida, Mishima e Peduzzi, 1999).

Ainda segundo as autoras, a produção da enfermagem nessa vertente é representada por estudos iniciais desenvolvidos entre a segunda metade de 1970 e a primeira metade de 1980, quais sejam: Contribuição ao estudo da prática de enfermagem - Brasil (Almeida et al, 1981), Educação e ideologia da enfermagem no Brasil (Germano, 1983), Introdução à análise das transformações da prática de enfermagem no Brasil no período de 1920-1978 (Silva et al, 1984) e Enfermagem profissional: análise crítica (Silva, 1986).

Segundo Almeida e Rocha (1997) a organização tecnológica da prática de enfermagem pode ser apreendida na sua relação com os outros trabalhos da saúde na sociedade capitalista e, nessa articulação, é reconhecida a complementaridade desse trabalho com os outros, bem como o espaço institucional e social em que se realiza. Ao analisar os processos de trabalho em saúde e, mais especificamente, os processos de trabalho da Enfermagem, é possível a apreensão das contradições e das dinâmicas da prática como parte do conjunto de estratégias de mudança da realidade.

Este trabalho toma então como referência a abordagem de Queiroz e Salum (1996, 2000), para quem o coletivo em sua dupla face - corpo individual e coletivo não é o objeto específico da Enfermagem, mas é, por excelência, objeto do processo de produção dos serviços de saúde ${ }^{2}$. Os trabalhadores coletivos da área da saúde, por sua vez, são os executores da política social pública de saúde, quer na estrutura central, regional ou local.

Para as autoras, esse processo de produção agrega distintos processos de trabalho - assistência, gerência, ensino e pesquisa - nos quais se integram as práticas sociais que a ele se subordinam. A prática social da Enfermagem, portanto, será apenas um dos instrumentos da engrenagem que sustenta o processo de produção dos

\footnotetext{
${ }^{2}$ Para Queiroz e Salum (1996), fundamentadas na produção de Breilh e Granda (1986), os perfis de reprodução social e de saúde-doença dos grupos sociais homogêneos compõem perfis epidemiológicos que constituem o objeto do processo de produção de serviços de saúde agregando potenciais de desgaste e de fortalecimento nas diferentes formas de trabalhar e de viver.
} 
serviços de saúde. Nessa perspectiva, os trabalhadores de saúde em geral, e os da enfermagem, em particular, são os sujeitos sociais que desempenham o trabalho em si nos distintos processos de trabalho das suas práticas sociais no cotidiano do serviço.

O processo de trabalho da assistência tem por objeto os perfis de reprodução social e de saúde-doença do indivíduo/família, grupos ou classes sociais e a totalidade, como finalidade a transformação desses perfis, visando o aperfeiçoamento dos processos saúde-doença do coletivo, agregando para meios e instrumentos os recursos materiais, os trabalhadores em saúde e saberes como a epidemiologia, a clínica, a educação em saúde entre outros (Queiroz e Salum, 1996).

Para a prática social da Enfermagem são específicos os meios e instrumentos de trabalho do processo de trabalho da assistência como, por exemplo, na dimensão indivíduo/família a consulta de enfermagem, a visita domiciliária e a prescrição de enfermagem e, na dimensão dos grupos ou classes sociais, por meio da articulação com as instituições do território podem-se realizar atividades que a realidade epidemiológica e sanitária exige como, por exemplo, a vacinação, as atividades educativas, entre outras (Queiroz e Salum, 1996).

Já

o objeto do processo de trabalho de gerenciamento da produção da assistência - no recorte da enfermagem - é a dinâmica de como se processa a assistência de enfermagem privilegiando ações sobre os perfis epidemiológicos do coletivo (que integra as metodologias de assistência sob a perspectiva da complementaridade da prática de enfermagem com as demais práticas sociais) e a finalidade especifica é a de compatibilizar essa dinâmica às necessidades de transformação dos perfis epidemiológicos. Dentre os instrumentos de trabalho, podemos destacar, entre outros, os modelos e os métodos gerenciais, o processo de educação continuada; o trabalho em si se dá sob a orientação do plano diretor para a saúde do município e pelo plano diretor para a assistência de enfermagem a ele subordinado (Queiroz, Salum, 2000). 
Por sua vez, o processo de trabalho do ensino tem por objeto o conhecimento prévio do aluno acerca do trabalho em saúde e como finalidade o aprimoramento da sua capacidade para o trabalho em saúde em consonância com a finalidade do trabalho que é o aperfeiçoamento dos perfis epidemiológicos. Para que ocorra de fato a transformação dos perfis, faz-se necessário que os alunos dominem seu processo de trabalho e os instrumentos utilizados para seu aprimoramento são os métodos pedagógicos (Queiroz e Salum, 1996).

Neste caso, a Enfermagem agregará especificamente o treinamento, avaliação e aprimoramento dos trabalhadores de enfermagem, a participação em bancas examinadoras para provimento de cargos da enfermagem e as atualizações do trabalho da enfermagem (Queiroz e Salum, 1996).

Finalmente, o processo de trabalho da pesquisa tem por objeto o estado da arte que caracteriza o saber/saber fazer da enfermagem. A finalidade diz respeito ao aperfeiçoamento desse saber, aproximando-se do objeto e da finalidade do processo de produção de serviços de saúde. Os instrumentos se referem aos referenciais teórico-metodológicos e ao conjunto de métodos e técnicas necessários à investigação científica (Queiroz e Salum, 2000).

Nos diferentes processos de trabalho - da assistência, gerência, ensino e pesquisa das práticas sociais em saúde que são os instrumentos da produção de serviços de saúde, os trabalhadores em saúde e, particularmente, os trabalhadores da enfermagem, são os instrumentos que realizam o próprio trabalho ou o trabalho em si (Queiroz e Salum, 1996).

\subsection{O processo de trabalho educativo em saúde}

O presente estudo enfatiza a discussão acerca da educação como parte indissociável das relações de produção, já que perpassa a atividade do trabalhador quando ele de algum modo se vale de seus conhecimentos técnicos específicos ao interferir no mundo, transformando a natureza e se transformando nesse processo.

A transformação da natureza é teleologicamente alcançada por meio da construção prévia da subjetividade sob a forma de uma finalidade que orientará todas as ações que virão a seguir. A prévia ideação portadora de uma finalidade para a 
produção do objeto de trabalho não é apenas um processo de objetivação, mas é também a exteriorização de um sujeito. A exteriorização da individualidade é também uma exteriorização historicamente determinada de desenvolvimento social; por isso, ao objetivar o objeto de trabalho, o indivíduo adquire novos conhecimentos, tanto da realidade exterior, como da sua própria individualidade (Lessa, 1996).

Conforme visto anteriormente, ainda que o trabalho em saúde seja fragmentado em múltiplos atos - componentes das chamadas práticas sociais em saúde -, a produção de serviços de saúde e, mais especificamente, a prática da enfermagem em saúde coletiva integra quatro grandes processos de trabalho (Queiroz, Salum, 1996):

1- o trabalho de assistência à saúde,

2- o de gerenciamento da assistência à saúde,

3- o de ensino para a qualificação dos trabalhadores em saúde e

4- o de investigação em saúde.

Os conhecimentos advindos da epidemiologia, da clínica e da educação em saúde, por exemplo, apoiarão esses distintos processos de trabalho, constituindo-se como instrumentos do processo de produção dos serviços em saúde e da prática da enfermagem em saúde coletiva.

Embora o processo educativo possa constituir em si um processo de trabalho, a educação aplicada à saúde pode ser vista pelo seu caráter instrumental nos diferentes processos de trabalho em saúde. Nesse sentido, um dos instrumentos de trabalho mais familiares à prática social da enfermagem no trabalho de assistência e de ensino à saúde são as atividades educativas (Soares, Salum, 1999).

Segundo Paro (2001), a educação, enquanto relação homem-homem, pode ser compreendida como a apropriação do saber historicamente produzido e é o recurso de que as sociedades dispõem para que a produção cultural da humanidade não se perca, passando de geração a geração. Desse modo, o autor acredita que a educação constitui a mediação pela qual os seres humanos garantem a perpetuação do seu caráter histórico. Isto é, se o homem se faz histórico porque é o construtor de sua própria humanidade, e se essa criação só se dá pela mediação dos conhecimentos, técnicas, valores, instrumentos - tudo enfim o que consubstancia a cultura construída pelos próprios homens - então a educação, ao propiciar a apropriação dessa cultura, é imprescindível para o desenvolvimento histórico. 
Entendida a educação como a apropriação de um saber (conhecimentos, valores, atitudes, comportamentos, etc) historicamente produzido, a consideração de seu produto não pode restringir-se ao ato de consumo imediato e completo, sem deixar nenhum vestígio. Nesse ato, o educando apropria-se de um saber que a ele é incorporado e se prolonga para além do ato de produção, por toda a vida do indivíduo. Há, portanto, algo que permanece para além do ato de aprender. Nesse sentido, o educando não se apresenta unicamente como consumidor do produto, mas também como objeto de trabalho da prática da atividade educativa. $\mathrm{O}$ educando é o verdadeiro objeto "sobre o qual" se processa o trabalho pedagógico e que com o agente do trabalho se "transforma" nesse processo, permanecendo para além dele (Paro, 2002b).

Por conseguinte, inspirando-se nas proposições de Paro (2002a) para a área da educação e transportando-as para a educação em saúde, pode-se afirmar que os usuários dos serviços de saúde não são apenas consumidores, por exemplo, da orientação individual ou do grupo educativo, além disso, agem no processo educativo em curso com vistas à consecução de um fim educativo, revelando sua dimensão de co-produção juntamente com as outras pessoas envolvidas também ativamente no processo pedagógico. Ao sustentar a dupla dimensão, como objeto de trabalho do agente educativo e de produtor, ou seja, de realizador de sua própria educação, configura-se a participação dos usuários dos serviços de saúde na atividade educativa não só como objeto, mas igualmente enquanto sujeito da educação.

Segundo Freire (2002), na prática problematizadora da realidade, os sujeitos desenvolvem o poder de captação e de compreensão do mundo que lhes aparece, em suas relações com ele, não mais como uma realidade estática, mas como uma realidade em transformação, em processo. Dessa forma, aprofundando a tomada de consciência da situação, os homens se "apropriam" dela como realidade histórica, por isso mesmo, capaz de ser transformada por eles.

A subjetividade do indivíduo, ao adquirir novas habilidades e conhecimentos, espontaneamente os generaliza de modo que sejam úteis não apenas para a singularidade da situação em que surgiram, mas para a maior parte dos momentos futuros, por mais diferenciados que sejam (Lessa, 1996).

Para tanto, o ponto de partida da educação para a compreensão dessa realidade é a contextualização da prática social que é comum, tanto para o agente, 
como para o sujeito da atividade educativa. Enquanto o agente da atividade educativa tem uma compreensão sintética, mas ainda precária da realidade, a compreensão dos sujeitos é inicialmente confusa e fragmentada - sincrética (Saviani, 2003).

Segundo o autor,

a compreensão dos agentes é sintética porque implica uma certa articulação dos conhecimentos e das experiências que detém relativamente à prática social. Todavia é precária uma vez que, por mais articulados que sejam os conhecimentos e as experiências, a inserção de sua própria prática pedagógica como uma dimensão da prática social envolve uma antecipação do que lhe será possível fazer com alunos cujos níveis de compreensão ele não pode conhecer, no ponto de partida, senão de forma precária. Por seu lado, a compreensão dos alunos é sincrética uma vez que, por mais conhecimentos e experiências que detenham, sua própria condição de alunos implica uma impossibilidade, no ponto de partida, de articulação da experiência pedagógica na prática social de que participam (Saviani, 2003:70).

O segundo passo na educação é a problematização e identificação dos temas centrais que precisam ser resolvidos no âmbito da prática social e, em conseqüência, a determinação de qual conhecimento é necessário dominar. Por sua vez, o terceiro passo é a instrumentalização teórica e prática necessária aos sujeitos da atividade educativa para a apropriação e equacionamento dos problemas detectados na prática social por meio das ferramentas culturais necessárias à luta social para a libertação das condições de exploração. O quarto passo será a catarse, entendida como a expressão elaborada da nova forma de entendimento da prática social a que se ascendeu na incorporação dos instrumentos culturais, transformados agora em elementos ativos de transformação social. E, finalmente, o quinto passo será a própria prática social, compreendida não mais em termos sincréticos pelos sujeitos (Saviani, 2003).

Partindo então do pressuposto que o objeto da produção de serviços em saúde são os perfis de reprodução social e de saúde-doença evidenciados no território e a finalidade é a sua transformação, visando o aperfeiçoamento dos processos saúde- 
doença de todos os habitantes, o trabalho em si das distintas práticas sociais corresponderá aos processos de trabalho (da assistência, gerência, ensino e investigação) necessários para tal produção e a educação em saúde estará inserida como instrumento, por exemplo, do processo de trabalho da assistência à saúde, a fim de criar possibilidades concretas para que a população participe como sujeito histórico co-produtor ativo da transformação de seus perfis.

De acordo com Paro (2002a), Merhy (1987), Gonzaga (1992a), Alves (1993), Cezar Vaz, Sena, Martins, Rubira, Santos, Cabreira et al (2003), entre outros autores, a educação é uma prática social, histórica e política que se articula com as outras práticas sociais, por isso, a ação educativa em saúde possui uma interdependência com a formação acadêmica de cada trabalhador, com o contexto histórico vivenciado e com a instituição em que essa prática se concretiza.

A ontologia lukacsiana reitera que a essência humana é historicamente determinada pela reprodução social: são os homens que fazem a própria história ainda que em circunstâncias que não escolheram, portanto, não há uma essência humana a-histórica que não possa ser subvertida pelos atos humanos (Lessa, 1996).

\subsubsection{O objeto do processo de trabalho educativo em saúde}

Mendes Gonçalves (1992) ressalta que o objeto de trabalho não se delimita por si mesmo, mas é delimitado pelo olhar de um sujeito que antevê em um certo fragmento da natureza um certo resultado potencial esboçado num projeto subjetivo. Toda objetualidade da natureza decorre da presença de um sujeito, para o qual ela é objeto, articulando subjetividade e objetividade. Se o sujeito transformar a si próprio enquanto se reproduz às custas da transformação da natureza, ambos se tornarão históricos.

Nesse sentido, entre a prévia ideação e o objeto de trabalho dela resultante reside a objetivação-exteriorização que é o construto humano ontológico do ser social que jamais coincidirá completamente com a finalidade que está na sua origem (Lessa, 1996).

Ainda segundo o autor, o resultado não corresponderá completamente à finalidade por que (Lessa, 1996:27):

1)existe o acaso presente nas objetivações, 
2)o fato do novo objeto desencadear nexos causais que jamais poderiam ser previstos em sua totalidade,

3)a individualidade que iniciou o processo de objetivação não é o mesmo daquela que o termina - novas habilidades e conhecimentos foram adquiridos enquanto o processo era efetivado e essas novas habilidades e conhecimentos são espontaneamente incorporados à prévia ideação adaptando-se às novas circunstâncias.

De acordo com Gonzaga (1992a), o trabalho da educação em saúde terá como objeto a práxis humana, entendida como articulação pensamento-ação e possibilidade de transposição do cotidiano a partir dele próprio.

Assim, o trabalho educativo em si, que pode ser planejado e executado

pelo conjunto de trabalhadores da saúde orientados por um projeto que articula clínica e epidemiologia, sob a perspectiva do pensamento social em saúde, na sua articulação, produzem a transformação no objeto (Queiroz e Salum, 1996).

Para Bernardo (1991:17) a prática é a inter-relação sujeito-sujeito [...] e a relação sujeito-objeto [...], cujos produtos são relativamente exteriorizados nessa prática.

Assim, pode-se empreender que o objeto do trabalho educativo da enfermagem em saúde coletiva, parte integrante do processo de construção do objeto da produção dos serviços de saúde e da própria prática de enfermagem em saúde coletiva será, portanto, a práxis humana, isto é, a articulação entre a ação sobre a vida material e a reflexão sobre a prática no cotidiano do trabalho.

Para Vázquez (1986), existem diferentes níveis de práxis, que variam de acordo com o grau de penetração da consciência do sujeito ativo no processo prático e com o grau de criação ou humanização da matéria transformada evidenciado no produto de sua atividade prática.

Os trabalhadores coletivos em saúde e, particularmente os trabalhadores da Enfermagem, têm na expressão do objeto do seu trabalho educativo o conhecimento 
acerca de algum aspecto da realidade social e de saúde a ser transformado que se exterioriza nos usuários dos serviços de saúde.

Todavia, enquanto o objeto de trabalho material impõe oposição à sua transformação passiva, a resposta do usuário de acordo com Paro (2002b:32),

se dá de acordo com sua especificidade humana, que é ao mesmo tempo natural e transcendência do natural. É, pois, uma participação ativa, enquanto ser histórico.

Por isso, conclui-se que o objeto do trabalho educativo da enfermagem em saúde coletiva somente atingirá a práxis humana quando o trabalhador assumir o usuário como objeto e co-produtor do seu trabalho, uma vez que,

num processo pedagógico legítimo, o educando não apenas está presente, mas também participa das atividades que aí se desenvolvem. A própria necessidade da participação ativa do aluno só se faz presente porque a educação supõe uma modificação na natureza do seu objeto (Paro, 2002a:144).

A especificidade do trabalho pedagógico pressupõe que o saber envolvido no processo educativo não pode ser expropriado do agente da atividade educativa sob pena de descaracterizar-se o próprio processo pedagógico, já que é o trabalhador que realiza o trabalho em si (Paro, 2002a).

Caso o trabalhador acredite que o usuário é apenas o objeto do seu trabalho, a atividade não potencializará sua participação ativa como sujeito co-produtor da atividade pedagógica. Enquanto objeto, será consumidor do produto no momento da sua produção e como sujeito, portador de um saber - matéria prima do processo, que dará substância e conteúdo a própria relação educador-educando (Paro, 2002a).

Por isso, o conhecimento do trabalhador coletivo de saúde e, mais especificamente, dos trabalhadores de enfermagem acerca do objeto de trabalho educativo será esquadrinhado por sua concepção de saúde e de educação. Esse 
conhecimento, que captura a partir da natureza aquilo que será objeto de trabalho educativo, subordina os saberes operantes/instrumentais ${ }^{3}$, por exemplo, a concepção de educação em saúde nos próximos passos constitutivos do processo de trabalho educativo em saúde.

\subsubsection{Os meios e instrumentos do processo de trabalho educativo em saúde}

A apreensão do objeto consiste basicamente na identificação de suas características que permitem a visualização do produto final, antevisto nas finalidades do trabalho (Mendes Gonçalves, 1994:61-62). Como esses produtos, enquanto expressões de necessidades são demarcados por características concretas de historicidade - e, nesse sentido, variam, - devem também variar os "vieses" dos procedimentos que, ao apreenderem o objeto, executam projeções do produto. Porém rigorosamente, os procedimentos em questão não apreendem o objeto, que nesse caso deveria ser suposto como existindo enquanto tal antes de sua apreensão que é variável; à medida que não existem objetos do trabalho senão no trabalho, tais procedimentos apreendem os objetos possíveis de trabalho (Mendes Gonçalves, 1994).

Para Marx (1968:205) a atividade do homem opera uma transformação, subordinada a um determinado fim, no objeto sobre que atua por meio do instrumental de trabalho.

Nesse sentido, os instrumentos de trabalho correspondem à maneira como os saberes operantes/instrumentais, recursos materiais e a força de trabalho constitutivos do trabalho concreto - que só transformar-se em trabalho abstrato por intermédio da troca como forma social de produção - se incorporam no processo de trabalho e sintetizam num produto um valor de uso, um material da natureza adaptado às necessidades humanas por meio da mudança de forma (Marx, 1968:205).

Já os meios de trabalho, dirigem a síntese da qualidade/utilidade do objeto e o projeto da finalidade, no sentido de que

\footnotetext{
${ }^{3}$ Segundo Paro (2002a) o saber fazer é o conhecimento que articula todos os elementos constitutivos do trabalho pedagógico e o saber que se passa é aquele que instrumentaliza a transformação do tema
} 
são uma coisa ou um complexo de coisas que o trabalhador insere entre si mesmo e o objeto de trabalho e lhe serve para dirigir sua atividade sobre esse objeto. Além disso, medem o desenvolvimento da força humana de trabalho e indicam as condições sociais em que se realiza o trabalho (Marx, 1968:203).

Ao integrar o processo de trabalho educativo, de que se vale a prática social da enfermagem, os instrumentos de trabalho correspondem ao trabalho morto incorporado ao objeto para atingir a finalidade - produto do processo de trabalho. E é preciso lembrar que, desse modo, os instrumentos de trabalho, por si só não garantirão o bom encaminhamento do processo de trabalho. A continuidade do processo de consumo dos instrumentos para a transformação do objeto dependerá da maneira como é recortado esse mesmo objeto, já que será o trabalho vivo do trabalhador de saúde dirigido ao recorte da natureza em que visualiza o objeto de trabalho que dará as diretrizes para uso dos instrumentos de trabalho (Marx, 1968 e Mendes Gonçalves, 1992).

Segundo Mendes Gonçalves (1992), algo só se tornará instrumento de trabalho quando o sujeito dotado de um projeto o utilizar, mas apenas enquanto se usar dele, se valer de suas qualidades, ou seja, de seu valor de uso.

Quando o trabalhador assume indiscriminadamente os instrumentos de trabalho e apóia todo seu processo de trabalho na sua reprodução sem considerar o recorte da natureza a ser transformada - objeto de trabalho -, os instrumentos não são utilizados em toda sua potencialidade. Como afirma Marx (1968:229), os trabalhadores se tornarão complementos vivos de um mecanismo morto que existirá independente deles.

\subsubsection{A finalidade do processo de trabalho educativo em saúde}

Para Mendes Gonçalves (1992), a atividade do trabalho humano está vinculada a uma finalidade sempre presente antes e durante o processo de trabalho.

para os sujeitos do processo de trabalho pedagógico. 
No fim do processo de trabalho aparece um resultado que já existia antes subjetivamente - na imaginação do trabalhador.

Ele não transforma apenas o material sobre o qual opera; ele imprime ao material o projeto que tinha conscientemente em mira, o qual constitui a lei determinante do seu modo de operar e ao qual tem de subordinar sua vontade (Marx, 1968:202).

Dessa maneira, a individualidade e a própria finalidade são transformadas ao longo do processo de objetivação-exteriorização. Todo processo de objetivação resulta necessariamente num processo objetivo de generalização dos resultados alcançados e a cada nova objetivação, a totalidade do ambiente no qual está inserido o indivíduo também se altera. Os atos singulares agem sobre os outros indivíduos que estão à sua volta fazendo com que todos os que vivem naquele ambiente estejam expostos às conseqüências e respondam às novas necessidades na exploração das novas possibilidades dispostas nas novas situações que surgem incessantemente (Lessa, 1996).

A finalidade do trabalho educativo da enfermagem em saúde coletiva será determinada pela transformação do objeto co-produtor a fim de alcançar a apropriação do que foi produzido historicamente para monitorar os perfis de reprodução social e de saúde-doença. Conseqüentemente, será a concretização do que foi antevisto antes de iniciado o processo educativo, ou seja, será a materialização da transformação do objeto co-produtor.

Para Cezar Vaz, Sena, Martins, Rubira, Santos, Cabreira et al (2003), se o que se quer nas atividades educativas é alcançar a dimensão social do usuário em suas determinações sociais e históricas, torna-se necessário assumir essas determinações como finalidade do trabalho e apropriar-se de instrumentos para sua transformação.

Como Queiroz e Salum (1996) consideram, a finalidade do processo de produção dos serviços de saúde será a transformação dos perfis de reprodução social e perfis saúde-doença nos grupos sociais homogêneos (objeto de trabalho) visando o aperfeiçoamento dos processos saúde-doença do coletivo. 
Se assim é, para o aperfeiçoamento dos perfis epidemiológicos do coletivo torna-se necessária a participação dos usuários no reconhecimento de suas formas de reprodução social, dos potenciais de desgaste e fortalecimento a que estão expostos e ainda das manifestações de desgaste e de fortalecimento que vão se evidenciando ao longo de suas vidas. Essa participação se dará na medida em que os trabalhos educativos com os usuários facilitem a apropriação das informações e conhecimentos que garantirão sua autonomia, a fim de que, como afirmam Queiroz e Salum (1996), haja o enfrentamento dos potenciais de desgaste e aperfeiçoamento dos potenciais de fortalecimento materializados nos seus processos saúde-doença. 


\section{PROCEDIMENTOS METODOLÓGICOS}

A pesquisa constituiu-se num estudo exploratório, descritivo e que se vale da revisão bibliográfica dirigida especificamente aos trabalhos que apresentaram relatos de experiência educativa dos enfermeiros brasileiros e que foram publicados entre 1988 e 2003.

Para tanto, utilizou-se como parâmetros na seleção, o fato de serem escritos por enfermeiros, docentes ou não, a partir de 1988, e que descrevessem um processo educativo em saúde voltado para uma dada população e realizado em unidades básicas de saúde ou em instituições sociais do território adscrito por uma unidade básica de saúde.

O ano de 1988 constituiu-se no marco temporal inicial a fim de que fossem percebidas as tendências na produção dos relatos de experiência educativa de educação em saúde dos enfermeiros decorrentes da promulgação da Constituição Federal que institui a saúde como direito social e dever do Estado.

A identificação das fontes bibliográficas foi realizada por meio do sistema informatizado de busca LILACS (Literatura Latino Americana de Ciências da Saúde) e PERIENF (Acervo de Periódicos da Escola de Enfermagem da Universidade de São Paulo). Os materiais selecionados no banco LILACS foram automaticamente excluídos do banco PERIENF.

Utilizou-se como indexadores de assunto, títulos, palavras e resumos, os termos educação, educação em saúde, educação em enfermagem, enfermagem, saúde pública, saúde coletiva, saúde comunitária, enfermagem em saúde pública, enfermagem em saúde coletiva, enfermagem em saúde comunitária, processo de trabalho, promoção da saúde e educação popular.

Nessa direção, num conjunto de 900 trabalhos encontrados, foram selecionados 111. Houve a necessidade de recorrer à fonte original dos trabalhos, uma vez que os resumos não informavam com precisão o local de estudo, a metodologia empregada, a graduação dos autores, o objetivo da atividade educativa, entre outros.

Esse novo filtro permitiu a compilação de 79 estudos, entre relatos de pesquisa e de experiência. Deles foram finalmente escolhidos 46 trabalhos (Anexo I) 
que, de fato, apresentavam a descrição minuciosa de um trabalho educativo realizado para a população de um determinado território.

A escolha metodológica desta pesquisa carregou um viés importante: o processo de trabalho educativo foi visto através de relatos recortados por aqueles que têm acesso a formulação estruturada das experiências e à publicação. Isto pode significar que configurou-se numa amostra exemplar da realidade de saúde na rede básica de serviços, correspondendo com a realidade em geral. Estudos devem ser realizados para promover tal análise dessa realidade do trabalho educativo da enfermagem na rede básica de saúde.

Ademais como o processo de trabalho diz imediatamente respeito ao cotidiano fala do uso de instrumentos, da ação em movimento que reúne conhecimento, experiência e ação prática - práxis de sujeitos e agentes em prol de uma dada transformação de um objeto - uma necessidade educativa a ser satisfeita a observação sistemática desse processo pode ajudar a sistematizar logicamente e compreender esse processo com mais clareza cercando a realidade de maneira mais abrangente.

\section{1 $O$ instrumento de coleta de dados e as categorias empíricas}

O instrumento de coleta de dados foi construído a partir das categorias empíricas e/ou indicadores e a partir das categorias de análise do processo de trabalho que compõem o marco teórico deste estudo (Anexo II).

Uma vez que o objeto é complexo e guarda em si uma lógica dialética processual que implica relação de co-produção na transformação do objeto (agentesujeito), tornou-se necessária a quantificação (quebra do processo em indicadores finitos, estanques, unidimensionais, que fragmentam ainda mais o objeto de estudo), a fim de capturar em maior extensão os elementos constituintes das atividades educativas descritas nos relatos de experiência dos enfermeiros.

Partindo do pressuposto de que a pesquisa necessita em primeiro lugar localizar o contexto em que se encontram os agentes que tomam como objeto de relato de experiência o processo educativo (Pêcheux, 1990 Fiorin, 1990), primeiramente, os artigos foram catalogados de acordo com a sua descrição geral levantando os seguintes dados de identificação (Figura I): ano de publicação (período) da atividade, área geográfica (região, município, bairro e comunidade) 
onde ocorreu a atividade educativa relatada, tipo de revista em que o relato de experiência foi publicado (específica de enfermagem ou multiprofissional) e características dos autores das publicações (local de vínculo, participação na publicação e caráter da instituição de vínculo).

Figura I - Categorias empíricas e indicadores que compõem a descrição geral dos relatos de experiência educativa dos enfermeiros brasileiros

\begin{tabular}{l|l}
\hline Categorias empíricas & \multicolumn{1}{|c}{ Indicadores } \\
\hline Ano de publicação & Período \\
\hline Área geográfica & Informação sobre a região de procedência \\
& $\begin{array}{l}\text { Informação sobre o município } \\
\text { Informação sobre o bairro }\end{array}$ \\
& Informação sobre a comunidade \\
\hline Tipo de revista & Revista específica de enfermagem \\
& Revista multiprofissional \\
\hline Autores & Local de vínculo \\
& Participação na publicação \\
Caráter da instituição de vínculo
\end{tabular}

A seguir, de acordo com a Figura II, o material foi agrupado com relação às características específicas do processo de trabalho educativo, e identificados o objeto, os meios, instrumentos e finalidade do trabalho que se fizeram evidentes ao longo da proposta analisada. 
Figura II - Componentes da categoria analítica do processo de trabalho, categorias empíricas e indicadores para captura do processo de trabalho educativo em saúde

\begin{tabular}{|c|c|c|}
\hline $\begin{array}{l}\text { Categoria analítica - processo de } \\
\text { trabalho }\end{array}$ & $\begin{array}{l}\text { Categorias } \\
\text { empíricas }\end{array}$ & Indicadores \\
\hline Objeto de trabalho & $\begin{array}{l}\text { Agente } \\
\text { Saber fazer } \\
\text { Objetivo } \\
\text { Sujeito }\end{array}$ & $\begin{array}{l}\text { Trabalhador/serviço envolvido no } \\
\text { planejamento } \\
\text { Trabalhador/serviço envolvido na } \\
\text { execução } \\
\text { Trabalhador/universidade envolvido no } \\
\text { planejamento } \\
\text { Trabalhador/universidade envolvido na } \\
\text { execução } \\
\text { Necessidade geradora } \\
\text { Concepção de educação } \\
\text { Concepção de saúde } \\
\text { Temática } \\
\text { Qualificação empírica } \\
\text { Participação no planejamento dos temas } \\
\text { Âmbito de atuação }\end{array}$ \\
\hline Meios/instrumentos de trabalho & $\begin{array}{l}\text { Local } \\
\text { Método } \\
\text { pedagógico } \\
\text { Extensão } \\
\text { Saber operante }\end{array}$ & $\begin{array}{l}\text { Espaço físico } \\
\text { Recurso didático } \\
\text { Freqüência dos encontros } \\
\text { Concepção de educação em saúde }\end{array}$ \\
\hline Finalidade do trabalho & Avaliados & $\begin{array}{l}\text { Presença de avaliação } \\
\text { Tipo de avaliação } \\
\text { Meta a ser alcançada } \\
\text { Articulação entre "saber fazer" e "saber } \\
\text { operante" } \\
\text { Tipo de avaliados }\end{array}$ \\
\hline
\end{tabular}

O objeto de trabalho foi encontrado mediante a descrição dos agentes envolvidos no processo de trabalho educativo, do saber/fazer, ou seja, da presença de concepções teóricas utilizadas nos relatos, dos objetivos descritos nos relatos e dos sujeitos para os quais a atividade educativa se destina:

I - Por referência aos agentes: 


\section{1) indicador de trabalhador/serviço e trabalhador/universidade envolvido no}

planejamento e na execução - qualifica a potência do agente e a natureza da instituição a que pertence para a transformação do objeto-sujeito da atividade educativa. Além disso, permite o paralelo entre os agentes que organizam a atividade e aqueles que de fato a executam para ser captada a divisão técnica do trabalho educativo da enfermagem na rede básica de serviços em saúde.

2) tomando por pressuposto que os agentes são os que se encontram em posição de captar e decodificar a realidade de saúde, objeto a ser transformado, elegeu-se o indicador de necessidade geradora para captar se o processo educativo relatado pelos agentes é instrumento do processo de trabalho da assistência ou do ensino de enfermagem.

II - Por referência ao "saber fazer":

3) indicador de concepção de educação e indicador de concepção de saúde vislumbra a potência do agente de olhar a natureza, recortar seu objeto de trabalho e traçar por meio de um "saber fazer" o processo de transformação do objeto-sujeito a partir de um referencial teórico que norteia seu trabalho pedagógico.

III - Por referência ao objetivo:

4) indicador de temática - que é o objetivo a ser trabalhado com os sujeitos da atividade educativa, indicando a práxis (maneira de pensar e de agir) que o agente considera necessário transformar;

IV - Por referência ao sujeito:

5) indicador de qualificação empírica dos sujeitos permitiu qualificar se os agentes identificam os sujeitos por meio do ciclo de vida em que se encontram; por meio do ciclo de vida em que se encontram associado a sua rede social; pela qualidade de ser usuário de uma instituição; por meio do ciclo de vida em que se encontram, do gênero e pela qualidade de ser usuário de uma instituição; e pela condição que vivenciam no momento da atividade educativa.

6) indicador de participação no planejamento dos temas - permite captar se os sujeitos representantes da população participam como co-produtores das necessidades tomadas pelo agente como sendo transformáveis em um processo 
educativo. A presença dos sujeitos no recorte dos temas a serem trabalhados na ação educativa favorece o compartilhamento do objeto a ser transformado.

7) indicador de âmbito de atuação - permite captar se o objeto tem caráter individual ou coletivo, este podendo ser definido como grupo de indivíduos ou como grupo com alguma comunalidade, de classe ou condição.

Nesse sentido, os meios e instrumentos de trabalho, foram identificados em primeiro lugar pelo:

8) indicador de espaço físico em que o agente concretiza o processo de trabalho educativo, considerando que o local onde se desenvolve o processo educativo nem sempre é o meio em que o agente trabalha cotidianamente.

9) indicador de recurso didático que capta a viabilidade de transformação concreta do objeto-sujeito no processo educativo e aponta para uma práxis reiterativa ou transformadora.

10) indicador de freqüência dos encontros, que por sua vez viabiliza a transformação do objeto-sujeitos no trabalho educativo em saúde a fim de, como Saviani (2003) explicita, se possam perceber os indícios das etapas do processo pedagógico.

11) o "saber operante" foi captado por meio do indicador de concepção de educação em saúde que permite vislumbrar a potência do agente de utilizar num processo de transformação do objeto-sujeito um referencial teórico que potencializa o alcance das finalidades propostas para seu trabalho pedagógico.

E, por fim para identificar os elementos relativos à finalidade do processo de trabalho educativo utilizou-se:

12) o indicador de presença de avaliação para demonstrar se houve preocupação em perceber algum nível de transformação do objeto;

13) o indicador de tipo de avaliação para comprovar se houve preocupação em captar transformações sucessivas durante o processo (avaliação de processo ensinoaprendizagem) e/ou se a finalidade do processo de trabalho educativo foi captada apenas no momento final do processo ou em outros momentos (avaliação de resultados a curto, médio e longo prazos); 
14) o indicador de meta a ser alcançada diz respeito a: adotar um comportamento saudável, discutir as causas dos problemas de saúde, prevenir uma certa doença ou agravo, controlar uma certa doença ou agravo; promover a melhoria das condições de vida na casa/bairro ou outro espaço ligado ao âmbito do consumo; promover a melhoria das condições de trabalho.

15)o indicador articulação "saber fazer" e "saber operante" a fim de captar indícios de articulação entre os saberes constituintes do "saber fazer" - concepção de educação e de saúde- para a captura do objeto de trabalho e o "saber operante"concepção de educação em saúde - que é parte dos instrumentos do processo de trabalho educativo em saúde.

16) e o indicador de tipo de avaliados, que captou quem foi avaliado, se o sujeito e/ou o agente do processo educativo.

A seguir, utilizou-se a análise de conteúdo para tratar e analisar as informações contidas nos relatos a fim de compreender o sentido do conteúdo manifesto ou latente e as significações explícitas ou ocultas (Chizzotti, 2001).

Finalmente, os dados encontrados foram tabulados no programa SPSS versão 13.0 e analisados conforme os indicadores selecionados a partir das suas freqüências absolutas e relativas. 


\section{RESULTADOS E ANÁLISE}

\subsection{Caracterização dos relatos de experiência educativa dos enfermeiros brasileiros na rede básica de serviços de saúde}

Entre os 46 relatos de experiência educativa selecionados pode-se observar de acordo com a Tabela 1 que 08 relatos $(17,4 \%)$ foram publicados entre 1988 e 1992, $18(39,1 \%)$ de 1993 a 1997 e $20(43,5 \%)$, entre 1998 e 2003. Conforme se havia pressuposto, houve um incremento gradual nas publicações desde 1988.

Tabela 1 - Relatos de experiência educativa dos enfermeiros brasileiros, no período 1988-2003

\begin{tabular}{ccc}
\hline Período de publicação & N & \% \\
\hline 1988 a 1992 & 8 & 17,4 \\
1993 a 1997 & 18 & 39,1 \\
1998 a 2003 & 20 & 43,5 \\
\hline Total & $\mathbf{4 6}$ & $\mathbf{1 0 0 , 0}$ \\
\hline
\end{tabular}

Em relação à procedência dos artigos, nota-se na Tabela 2 que $16(34,7 \%)$ relatos provinham da região sul, $15(32,6 \%)$ da região sudeste, $08(17,4 \%)$ da região nordeste, $02(4,4 \%)$ da região centro-oeste, $01(2,2 \%)$ da região norte e $04(8,7 \%)$ não indicavam sua origem. Chama a atenção o dado relativo ao equilíbrio entre as regiões sul e sudeste, que constituem as regiões mais desenvolvidas do país. 
Tabela 2 - Relatos de experiência educativa dos enfermeiros brasileiros quanto à região de procedência da atividade educativa, no período 1988-2003

\begin{tabular}{ccc}
\hline Regiões & $\mathbf{N}$ & $\mathbf{\%}$ \\
\hline Sul & 16 & 34,7 \\
Sudeste & 15 & 32,6 \\
Nordeste & 08 & 17,4 \\
Centro-oeste & 02 & 4,4 \\
Norte & 01 & 2,2 \\
Sem Informação & 04 & 8,7 \\
\hline Total & $\mathbf{4 6}$ & $\mathbf{1 0 0 , 0}$ \\
\hline
\end{tabular}

As tabelas 3, 4 e 5 tratam de relacionar a existência de informações referentes ao lócus onde a atividade educativa relatada foi desenvolvida. Observa-se que houve maior preocupação em identificar o município em que ela foi realizada - presente em $39(84,8 \%)$ dos relatos (Tabela 3$)$. De outro lado, uma grande maioria não informava nem o bairro, foco da atividade educativa (33 relatos, 71,7\% - Tabela 4) nem a comunidade a que ela se dirigiu (29 relatos, 63\% - Tabela 5).

Tabela 3 - Relatos de experiência educativa dos enfermeiros brasileiros quanto à informação sobre o município em que ocorreu a atividade educativa, no período 1988-2003

\begin{tabular}{ccc}
\hline Informação sobre o município & $\mathbf{N}$ & $\mathbf{\%}$ \\
\hline Sim & 39 & 84,8 \\
Não & 07 & 15,2 \\
\hline Total & $\mathbf{4 6}$ & $\mathbf{1 0 0 , 0}$ \\
\hline
\end{tabular}


Tabela 4 - Relatos de experiência educativa dos enfermeiros brasileiros quanto à informação sobre o bairro em que ocorreu a atividade educativa, no período 19882003

\begin{tabular}{ccc}
\hline Informação sobre o bairro & $\mathbf{N}$ & $\mathbf{\%}$ \\
\hline Sim & 13 & 28,3 \\
Não & 33 & 71,7 \\
\hline Total & $\mathbf{4 6}$ & $\mathbf{1 0 0 , 0}$ \\
\hline
\end{tabular}

Tabela 5 - Relatos de experiência educativa dos enfermeiros brasileiros quanto à informação sobre a comunidade em que se dirigiu a atividade educativa, no período 1988-2003

\begin{tabular}{ccc}
\hline Informação sobre a comunidade & $\mathbf{N}$ & $\mathbf{\%}$ \\
\hline Sim & 17 & 37,0 \\
Não & 29 & 63,0 \\
\hline Total & $\mathbf{4 6}$ & $\mathbf{1 0 0 , 0}$ \\
\hline
\end{tabular}

Quanto ao veículo de publicação dos artigos examinados, como mostra a Tabela 6, a publicação dos relatos de experiência sobre educação em saúde na rede básica de serviços de saúde foi feita majoritariamente em revistas específicas de enfermagem - $40(86,8 \%)$ - e somente $06(13,2 \%)$ artigos foram publicados em outras revistas não específicas de enfermagem - Revista Ciências da Saúde, Revista Brasileira de Saúde do Escolar, Saúde em Debate e O Mundo da Saúde. 
Tabela 6 - Relatos de experiência educativa dos enfermeiros brasileiros quanto ao tipo de revista em que foi publicada a atividade educativa, no período 1988-2003

\begin{tabular}{ccc}
\hline Tipo de revista & $\mathbf{N}$ & $\mathbf{\%}$ \\
\hline Enfermagem & 40 & 86,8 \\
Multiprofissional & 06 & 13,2 \\
\hline Total & $\mathbf{4 6}$ & $\mathbf{1 0 0 , 0}$ \\
\hline
\end{tabular}

No que diz respeito ao local de vínculo dos autores das publicações, pode-se observar por meio da Tabela 7 que os enfermeiros com algum tipo de vinculação aos serviços básicos de saúde participaram somente de $08(17,4 \%)$ das publicações e não participaram em $38(82,6 \%)$ dos relatos. Já os alunos de graduação participaram de $08(17,4 \%)$ publicações e em $38(82,6 \%)$ relatos não participaram. Em relação aos alunos de pós-graduação houve a participação em 21 (45,7\%) publicações e em 25 $(54,3 \%)$ relatos estes alunos não participaram. Os autores docentes foram os que majoritariamente participaram das publicações, tendo sido 42 (91,3\%) os relatos assinados por eles. Somente em 04 (8,7\%) relatos os docentes não participaram.

Pode-se apreender que a participação dos enfermeiros trabalhadores da rede básica de serviços de saúde e dos alunos de graduação são comparativamente iguais, e com freqüências bastante baixas quando comparadas à participação dos docentes e dos alunos de pós graduação, cuja presença é predominante nas publicações dos relatos de experiência. Dessa forma, apreende-se que os relatos são na sua maioria assinados por docentes e alunos de pós-graduação. 
Tabela 7 - Relatos de experiência educativa dos enfermeiros brasileiros quanto ao local de vínculo e participação dos autores nas publicações, no período 1988-2003

\begin{tabular}{ccc}
\hline Enfermeiros da rede básica de serviços de saúde & N & $\%$ \\
\hline Participação nas publicações & 08 & 17,4 \\
Não participação & 38 & 82,6 \\
Total & 46 & 100,0 \\
\hline Aluno de graduação em Enfermagem & $\mathbf{N}$ & $\mathbf{\%}$ \\
\hline Participação nas publicações & 08 & 17,4 \\
Não participação & 38 & 82,6 \\
Total & 46 & 100,0 \\
\hline Aluno de pós-graduação em Enfermagem & $\mathbf{N}$ & $\mathbf{\%}$ \\
\hline Participação nas publicações & 21 & 45,7 \\
Não participação & 25 & 54,3 \\
Total & 46 & 100,0 \\
\hline Docente em Enfermagem & $\mathbf{N}$ & $\mathbf{\%}$ \\
\hline Participação nas publicações & 42 & 91,3 \\
Não participação & 04 & 8,7 \\
Total & 46 & 100,0 \\
\hline
\end{tabular}

Ainda quanto ao local de vínculo dos autores, no que diz respeito ao caráter da instituição - público ou privado - pode se verificar, na Tabela 8 , que 39 (84,6\%) eram instituições públicas, $05(11,0 \%)$ eram instituições privadas e $02(4,4 \%)$ eram parcerias entre instituições públicas e privadas; o que leva a crer que este objeto é de interesse do setor público. 
Tabela 8 - Relatos de experiência educativa dos enfermeiros brasileiros quanto ao caráter da instituição vinculada aos autores das publicações, no período 1988-2003

\begin{tabular}{ccc}
\hline Caráter da instituição & N & \% \\
\hline Público & 39 & 84,6 \\
Privado & 05 & 11,0 \\
Público e privado & 02 & 4,4 \\
\hline Total & $\mathbf{4 6}$ & $\mathbf{1 0 0 , 0}$ \\
\hline
\end{tabular}

\subsection{Descrição dos elementos constituintes do processo de trabalho educativo em saúde a partir dos relatos de experiência educativa dos enfermeiros brasileiros na rede básica de serviços de saúde}

\subsubsection{O objeto do trabalho educativo em saúde}

Dado que não foi encontrado nos relatos o objeto a que os trabalhos educativos estavam referidos, ou seja, o que pretendiam transformar ao final do processo, os objetos dos processos de trabalho educativos foram construídos a partir da análise de dados sobre os agentes, as concepções de educação e saúde apresentadas, os objetivos dos relatos de experiência dos trabalhos educativos e os sujeitos para os quais a atividade educativa se destinou.

A análise dos dados sobre os agentes iniciou-se pela verificação da divisão do trabalho, que pode ser visualizada pela combinação da divisão entre os que participam do planejamento e os que participam da execução do trabalho em si, e da divisão entre os agentes da rede básica de serviços de saúde ou dos serviços relacionados à educação básica que participaram do processo e os agentes ligados à universidade. Dessa forma, foi possível perceber uma dada organização do trabalho educativo.

Assim, foram considerados os agentes explicitamente referidos nos relatos. Note-se que nem sempre os relatos davam conta de qualificar os agentes envolvidos. Além disso, os agentes que planejavam as atividades não necessariamente as executavam e vice-versa. É por isso que os totais aqui expressos são diferentes. 
Com relação aos agentes dos serviços da rede básica de serviços de saúde ou relacionadas à educação básica (Figura III), nota-se comparativamente um equilíbrio numérico entre os que participaram do planejamento (17), a partir da captação e da decodificação dos temas apreendidos relativos às necessidades geradoras, e da execução (18) propriamente dita do processo educativo em saúde.

Figura III - Agentes da rede básica de serviços de saúde ou relacionadas à educação básica que participaram do planejamento dos temas e/ou da execução do trabalho educativo em saúde

\begin{tabular}{cccc}
\hline Planejamento dos temas & N & Execução do trabalho & N \\
\hline Enfermeira/UBS & 4 & Enfermeira/UBS & 5 \\
Funcionários, professor e/ou diretor/escola & 4 & Médico, dentista e/ou & 4 \\
& & psicólogo/UBS & \\
Dentista assessor/secretaria municipal da & 2 & Farmacêutica/pastoral, & 3 \\
saúde, professor e diretor/creche e/ou & & Bombeiros ou & \\
dentista e médico/instituição religiosa & & Enfermeira/maternidade & \\
Médico, dentista e/ou psicólogo/UBS & 2 & Dentista e/ou enfermeira & 2 \\
& & assessora/secretaria municipal da & \\
Agricultor/sindicalista ou diretor/creche & 2 & saúde & 1 \\
Auxiliar de enfermagem/UBS & 1 & Auxiliar de enfermagem/UBS & 1 \\
Funcionários/UBS & 1 & Agente de saúde/UBS & 1 \\
Enfermeira/maternidade e diretor/escola & 1 & Diretor/creche & 1 \\
\hline Total & $\mathbf{1 7}$ & Total & $\mathbf{1 8}$ \\
\hline
\end{tabular}

Por sua vez, a Figura IV permite a visualização dos agentes das universidades que participaram do planejamento dos temas e/ou da execução do trabalho educativo em si. Verifica-se, particularmente, um contraste entre o número de alunos de graduação em enfermagem que planejaram os temas (1) e aqueles que executaram o processo educativo em saúde (14). 
Figura IV - Agentes das universidades que participaram do planejamento dos temas e/ou da execução do trabalho educativo em saúde

\begin{tabular}{|c|c|c|c|}
\hline Planejamento dos temas & $\mathbf{N}$ & Execução do trabalho & $\mathbf{N}$ \\
\hline Docente/Enfermagem & 23 & $\begin{array}{c}\text { Aluno de } \\
\text { graduação/Enfermagem }\end{array}$ & 14 \\
\hline Aluno de graduação e docente/Enfermagem & 8 & Docente/Enfermagem & 9 \\
\hline $\begin{array}{l}\text { Aluno de pós-graduação e } \\
\text { docente/Enfermagem }\end{array}$ & 6 & $\begin{array}{l}\text { Aluno de pós- } \\
\text { graduação/Enfermagem }\end{array}$ & 6 \\
\hline $\begin{array}{c}\text { Docentes/Pedagogia, Engenharia Agrícola, } \\
\text { Fisioterapia, Jornalismo, Medicina e Saúde } \\
\text { Pública }\end{array}$ & 3 & $\begin{array}{l}\text { Aluno de graduação e } \\
\text { docente/Enfermagem }\end{array}$ & 6 \\
\hline $\begin{array}{l}\text { Alunos de graduação/Pedagogia, } \\
\text { Engenharia Agrícola, Nutrição, Rádio e TV, } \\
\text { Fisioterapia, Educação Física e Odontologia }\end{array}$ & 3 & $\begin{array}{c}\text { Alunos de graduação/ } \\
\text { Fisioterapia, Odontologia, } \\
\text { Pedagogia, } \\
\text { Educação Física, Comunicação, } \\
\text { Economia, Educação Artística, } \\
\text { Rádio e TV }\end{array}$ & 4 \\
\hline $\begin{array}{c}\text { Aluno de graduação, pós-graduação e } \\
\text { docente/Enfermagem }\end{array}$ & 3 & $\begin{array}{l}\text { Aluno de graduação, pós- } \\
\text { graduação e } \\
\text { docente/Enfermagem }\end{array}$ & 4 \\
\hline $\begin{array}{l}\text { Especialista assistente e } \\
\text { docente/Enfermagem }\end{array}$ & 2 & $\begin{array}{c}\text { Aluno de pós-graduação e } \\
\text { docente/Enfermagem }\end{array}$ & 2 \\
\hline Aluno de pós-graduação/Enfermagem & 1 & $\begin{array}{l}\text { Aluno de graduação, especialista } \\
\text { assistente e docente/Enfermagem }\end{array}$ & 1 \\
\hline Aluno de graduação/Enfermagem & 1 & Docente/Medicina & 1 \\
\hline Total & 50 & Total & 47 \\
\hline
\end{tabular}

A seguir, mostra-se que tipo de necessidade os agentes captaram e decodificaram para, dessa forma, engendrarem processos de trabalhos educativos, como resposta a essas necessidades. Nesse sentido, a Tabela 9 apresenta as necessidades geradoras dos trabalhos educativos. Evidencia-se que 42 (91,3\%) trabalhos educativos foram disparados pelas necessidades atinentes ao ensino de 
enfermagem e que em apenas $4(8,7 \%)$ relatos a necessidade disparadora foi atinente à assistência de enfermagem.

Tabela 9 - Relatos de experiência educativa dos enfermeiros brasileiros quanto as necessidades geradoras do trabalho educativo, no período 1988-2003

\begin{tabular}{ccc}
\hline Necessidade geradora & $\mathbf{N}$ & $\mathbf{\%}$ \\
\hline Ensino de enfermagem & 42 & 91,3 \\
Assistência de enfermagem & 4 & 8,7 \\
\hline Total & $\mathbf{4 6}$ & $\mathbf{1 0 0 , 0}$ \\
\hline
\end{tabular}

A presença das concepções de educação e de saúde que, conforme tomadas no referencial teórico-metodológico deste trabalho, direcionam o olhar do agente num "saber fazer" - para o recorte do objeto de trabalho pode ser acompanhada na Tabela 10. Nota-se que 23 relatos (50\%) apresentam a explicitação das concepções tanto de educação quanto de saúde, 14 (30,4\%) somente de educação, 7 (15,2\%) somente de saúde e que 2 relatos (4,4\%) não apresentam essas informações.

Tabela 10 - Relatos de experiência educativa dos enfermeiros brasileiros quanto a presença das concepções de educação e de saúde constituintes do "saber fazer" do trabalho educativo, no período 1988-2003

\begin{tabular}{ccc}
\hline Presença das concepções constituintes do "saber fazer" & N & \% \\
\hline Saúde e educação & 23 & 50 \\
Educação & 14 & 30,4 \\
Saúde & 7 & 15,2 \\
Sem informação & 2 & 4,4 \\
\hline Total & $\mathbf{4 6}$ & $\mathbf{1 0 0 , 0}$ \\
\hline
\end{tabular}

A temática dos trabalhos foi apreendida através do objetivo explicitado nos relatos analisados. Houve uma variação muito grande dos temas, mesmo assim, pode-se observar que $22 \%$ das temáticas eram sobre saúde e problema de saúde, $19,8 \%$ sobre sexualidade e saúde reprodutiva, $11 \%$ sobre aids/dst's, 8,7\% sobre 
prevenção de doenças e promoção da saúde e 4,4\% sobre a importância do lúdico. Nota-se que em 33\% dos trabalhos restantes, os temas são individualizados aparecendo somente uma vez. O detalhamento dos temas encontrados nos relatos de experiência educativa dos enfermeiros brasileiros, encontra-se no anexo III.

A qualificação empírica dos sujeitos permitiu agrupá-los de acordo com a identificação que lhes foi atribuída nos relatos. Assim, os agentes identificam os sujeitos por meio do ciclo de vida em que se encontravam (14 adolescentes; 1 criança; 1 adulto), por meio do ciclo de vida em que se encontravam e sua rede social ( 2 adolescentes com os trabalhadores da escola e/ou familiares; 2 crianças com seus familiares e/ou trabalhadores da escola, 1 adulto e seus familiares); pela qualidade de ser usuário de uma instituição (2 estudantes e demais membros da comunidade escolar, 1 estudante e trabalhadores de serviços de saúde), por meio do ciclo de vida em que se encontravam, do gênero e pela qualidade de ser usuário de uma instituição (2 crianças usuárias de UBS, 3 mulheres usuárias de UBS, 1 mãe com criança em creche; 1 adulto usuário de UBS) e pela condição que vivenciavam no momento da atividade educativa ( 3 população em geral; 3 população rural assentada/semi-rural, 1 transeunte, 2 ouvintes de rádio e/ou leitor de jornal, 6 trabalhadores).

O que se observa é que a maioria dos sujeitos (28 relatos - 60,9\%) foi de alguma forma identificado a partir do ciclo de vida em que se encontravam, observando-se uma tendência a associar-se ao ciclo de vida alguma outra qualificação do sujeito (12 dos 28 relatos - 42,9\%), seja a instituição que freqüentavam ou a rede social com que contavam.

Note-se que 16 destes sujeitos foram identificados como adolescentes $(57,1 \%$ de 28 relatos). Quase não se observam sujeitos identificados apenas pela instituição que freqüentavam ( 3 casos $-6,5 \%$ dos 46 relatos).

A condição do sujeito como trabalhador foi apontada em 6 relatos (13\% do total de relatos). A explicitação do sujeito como morador de um espaço social específico foi apontada em 3 relatos (6,5\%). Observa-se, no entanto, que $6(13 \%)$ sujeitos não foram identificados a não ser por sua qualidade de fazer parte da população em geral, serem transeuntes e/ou ouvintes e leitores.

Com relação à participação dos sujeitos na escolha dos temas a serem abordados foi possível apreender que há uma tendência nos relatos a incluir os sujeitos no planejamento, embora ainda em menor número do que as experiências nas quais os temas são definidos pelos agentes da ação. Observa-se na Tabela 11 que 
em $21(45,7 \%)$ relatos os sujeitos participaram da elaboração dos temas, o que supõe a presença de co-produção no trabalho educativo e em $25(54,3 \%)$ eles não participaram.

Tabela 11 - Relatos de experiência educativa dos enfermeiros brasileiros quanto a participação dos sujeitos no planejamento dos temas dos trabalhos educativos, no período 1988-2005

\begin{tabular}{ccc}
\hline Participação dos sujeitos no planejamento dos temas & N & $\%$ \\
\hline Sim & 21 & 45,7 \\
Não & 25 & 54,3 \\
\hline Total & $\mathbf{4 6}$ & $\mathbf{1 0 0 , 0}$ \\
\hline
\end{tabular}

Foram ainda classificados os âmbitos de atuação dos trabalhos educativos, que permitem captar se o objeto tem caráter individual ou coletivo, este podendo ser definido como grupo de indivíduos ou como grupo com alguma comunalidade, de classe ou outra condição. Em primeiro lugar encontrou-se o grupo definido pela condição de estar na escola pública ou creche $(18$ - 39,1\%), em segundo lugar, o grupo definido pela condição de colocar indivíduos juntos $(16-34,8 \%)$, em seguida veio o grupo definido pela sua condição de baixa renda ( 5 - 10,9\%), o grupo definido pela condição de estar freqüentando um curso de assuntos gerais $(3-6,5 \%)$, em igual freqüência contabilizou-se o grupo definido pelo seu agravo $(3-6,5 \%)$, por último ficou o grupo definido pela sua condição de participação política $(1-2,2 \%)$.

Para finalizar, as Figuras V a XI mostram o objeto deduzido a partir de suas partes: o sujeito para o qual a atividade educativa se destina, o tema que se focalizou na atividade educativa e o âmbito de atuação que caracteriza o sujeito. Note-se que os quadros foram construídos a partir da definição dos sujeitos. 
Figura V - Adolescentes, pais e professores: temas e âmbito de atuação grupal

\begin{tabular}{|c|c|c|}
\hline & Objeto & \\
\hline Sujeito & Tema & Âmbito de atuação grupal \\
\hline \multirow[t]{14}{*}{ Adolescentes } & $\begin{array}{llr}\text { Lacunas de } & \text { conhecimento } & \text { sobre } \\
\text { sexualidade } & \text { e cidadania } & \text { na } \\
\text { adolescência } & & \\
\end{array}$ & - $\quad$ Escola pública \\
\hline & $\begin{array}{l}\text { - Lacunas de conhecimento sobre } \\
\text { saúde }\end{array}$ & - $\quad$ Escola pública \\
\hline & $\begin{array}{l}\text { - Lacunas de conhecimento sobre } \\
\text { sexualidade na adolescência }\end{array}$ & - $\quad$ Escola pública \\
\hline & $\begin{array}{l}\text { - Lacunas de conhecimento sobre } \\
\text { doenças sexuais de transmissão } \\
\text { direta e indireta }\end{array}$ & - $\quad$ Escola pública \\
\hline & $\begin{array}{l}\text { - Lacunas de conhecimento sobre } \\
\text { saúde sexual }\end{array}$ & - $\quad$ Escola pública \\
\hline & $\begin{array}{l}\text { - Lacunas de conhecimento sobre } \\
\text { sexualidade na adolescência }\end{array}$ & - $\quad$ Escola pública \\
\hline & $\begin{array}{l}\text { - Lacunas de conhecimento sobre a } \\
\text { transmissão do HIV }\end{array}$ & - $\quad$ Escola pública \\
\hline & $\begin{array}{l}\text { - Lacunas de conhecimento sobre } \\
\text { HIV/Aids }\end{array}$ & - $\quad$ Escola pública \\
\hline & $\begin{array}{l}\text { - Lacunas de conhecimento sobre } \\
\text { primeiros socorros }\end{array}$ & $\begin{array}{l}\text { - Curso de patrulheirismo } \\
\text { de uma favela }\end{array}$ \\
\hline & $\begin{array}{l}\text { - Lacunas de conhecimento sobre } \\
\text { higiene relacionada ao uso de } \\
\text { drogas, gravidez indesejada e dst's }\end{array}$ & $\begin{array}{l}\text { - Moradores de rua } \\
\text { matriculados } \\
\text { escola aberta }\end{array}$ \\
\hline & $\begin{array}{l}\text { Lacunas de conhecimento sobre os } \\
\text { direitos sexuais e reprodutivos }\end{array}$ & - $\quad$ Surdez \\
\hline & $\begin{array}{l}\text { - Lacunas de conhecimento sobre } \\
\text { educação sexual e reprodutiva }\end{array}$ & - $\quad$ Surdez \\
\hline & $\begin{array}{l}\text { - Lacunas de conhecimento sobre } \\
\text { educação sexual e reprodutiva }\end{array}$ & $\begin{array}{l}\text { - Centro de Juventude de } \\
\text { uma comunidade de } \\
\text { baixa renda }\end{array}$ \\
\hline & $\begin{array}{l}\text { - Lacunas de conhecimento sobre } \\
\text { aids/dst's }\end{array}$ & - Conjunto de indivíduos \\
\hline $\begin{array}{l}\text { Adolescentes e } \\
\text { professores }\end{array}$ & $\begin{array}{l}\text { - Lacunas de espaço para discussão da } \\
\text { sexualidade e gravidez na } \\
\text { adolescência }\end{array}$ & - $\quad$ Escola pública \\
\hline
\end{tabular}


Figura VI - Pais, alunos, professores e funcionários: temas e âmbito de atuação grupal

\begin{tabular}{|c|c|c|}
\hline \multicolumn{3}{|c|}{ Objeto } \\
\hline Sujeito & Tema & Âmbito de atuação grupal \\
\hline $\begin{array}{l}\text { Pais, alunos, professores e } \\
\text { funcionários }\end{array}$ & $\begin{array}{l}\text { - } \\
\text { As concepções sobre saúde } \\
\text { e os problemas de saúde } \\
\text { - Lacunas de conhecimento } \\
\text { sobre saúde }\end{array}$ & $\begin{array}{l}\text { - } \\
\text { - Escola pública } \\
\text { - Escola pública }\end{array}$ \\
\hline $\begin{array}{l}\text { Professores e funcionários de } \\
\text { escolas, profissionais das } \\
\text { UBS's e do PROASE }\end{array}$ & $\begin{array}{l}\text { - Lacunas de conhecimento } \\
\text { sobre a epidemiologia das } \\
\text { doenças transmissíveis }\end{array}$ & $\begin{array}{lr}\text { - } & \text { Conjunto } \\
& \text { indivíduos } \\
\text { escolas, UBS's } & \text { e } \\
\text { PROASE } & \end{array}$ \\
\hline
\end{tabular}

Figura VII - Crianças, familiares e comunidade escolar: temas e âmbito de atuação grupal

\begin{tabular}{|c|c|c|}
\hline \multicolumn{3}{|c|}{ Objeto } \\
\hline Sujeito & Tema & Âmbito de atuação grupal \\
\hline Crianças & $\begin{array}{l}\text { - Discussão sobre as } \\
\text { causas das doenças }\end{array}$ & - $\quad$ Escola pública \\
\hline Crianças e suas mães & $\begin{array}{lll}- & \text { Lacunas } & \text { de } \\
\text { conhecimento sobre os } & \\
\text { problemas de saúde } & \end{array}$ & - $\quad$ Pré-escola pública \\
\hline $\begin{array}{l}\text { Crianças, pais, professores e } \\
\text { diretor }\end{array}$ & $\begin{array}{l}\text { - Lacunas } \\
\text { conhecimento sobre os } \\
\text { problemas de saúde }\end{array}$ & - $\quad$ Escola pública \\
\hline $\begin{array}{l}\text { Crianças e seus responsáveis } \\
\text { usuários da UBS }\end{array}$ & $\begin{array}{llr}\text { - } & \text { Lacunas } & \text { de } \\
\text { conhecimento sobre a } & \text { áde das crianças }\end{array}$ & - $\quad$ Conjunto de indivíduos \\
\hline & $\begin{array}{lr}\text { - } & \text { Lacunas } \\
\text { conhecimento } & \text { que } \\
\text { interferem na saúde } \\
\text { mental }\end{array}$ & - Conjunto de indivíduos \\
\hline
\end{tabular}


Figura VIII - Mulheres e mães: temas e âmbito de atuação grupal

\begin{tabular}{|c|c|c|}
\hline \multicolumn{3}{|c|}{ Objeto } \\
\hline Sujeito & Tema & Âmbito de atuação grupal \\
\hline $\begin{array}{l}\text { Mulheres usuárias de uma } \\
\text { UBS }\end{array}$ & 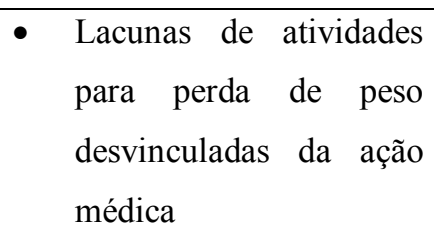 & - Conjunto de indivíduos \\
\hline $\begin{array}{l}\text { Mulheres em } \quad \text { idade } \\
\text { reprodutiva usuárias de uma } \\
\text { UBS }\end{array}$ & $\begin{array}{l}\text { - Lacunas de } \\
\text { conhecimento sobre o } \\
\text { câncer de colo de útero }\end{array}$ & - Conjunto de indivíduos \\
\hline $\begin{array}{l}\text { Mulheres climatéricas usuárias } \\
\text { da UBS }\end{array}$ & $\begin{array}{lr}\text { - } & \text { Lacunas } \\
\text { conhecimento } & \text { sobre } \\
\text { estratégias } & \text { de } \\
\text { enfrentamento } & \text { do } \\
\text { climatério } & \end{array}$ & - Conjunto de indivíduos \\
\hline Mães com crianças em creche & $\begin{array}{l}\text { - Lacunas } \\
\text { conhecimento sobre o } \\
\text { cuidado de crianças } \\
\text { desnutridas }\end{array}$ & $\begin{array}{l}\text { - Conjunto de mães com } \\
\text { crianças desnutridas na } \\
\text { creche }\end{array}$ \\
\hline
\end{tabular}

Figura IX - Adultos: temas e âmbito de atuação grupal

\begin{tabular}{|c|c|c|}
\hline \multicolumn{3}{|c|}{ Objeto } \\
\hline Sujeito & Tema & Âmbito de atuação grupal \\
\hline $\begin{array}{l}\text { Adultos usuários da UBS a } \\
\text { partir de } 48 \text { anos }\end{array}$ & $\begin{array}{l}\text { - Conhecimento sobre o } \\
\text { autocuidado do diabetes }\end{array}$ & - Conjunto de indivíduos \\
\hline $\begin{array}{l}\text { Adultos sadios ou portadores } \\
\text { de doenças crônicas }\end{array}$ & $\begin{array}{l}\text { - Lacunas de } \\
\text { conhecimento sobre } \\
\text { prevenção de doenças e } \\
\text { promoção da saúde }\end{array}$ & - Conjunto de indivíduos \\
\hline Adultos noivos & $\begin{array}{llr}\text { - } & \text { Lacunas } & \text { de } \\
\text { conhecimento } & \text { sobre } \\
\text { paternidade } & \mathrm{e} \\
\text { maternidade } & \\
\text { responsáveis } & \end{array}$ & $\begin{array}{l}\text { - Noivos matriculados } \\
\text { num curso pré-nupcial } \\
\text { católico }\end{array}$ \\
\hline
\end{tabular}

Figura X - População em geral, transeuntes e ouvintes de rádio: temas e âmbito de atuação grupal 


\begin{tabular}{|c|c|c|}
\hline \multicolumn{3}{|c|}{ Objeto } \\
\hline Sujeito & Tema & Âmbito de atuação grupal \\
\hline População em geral & 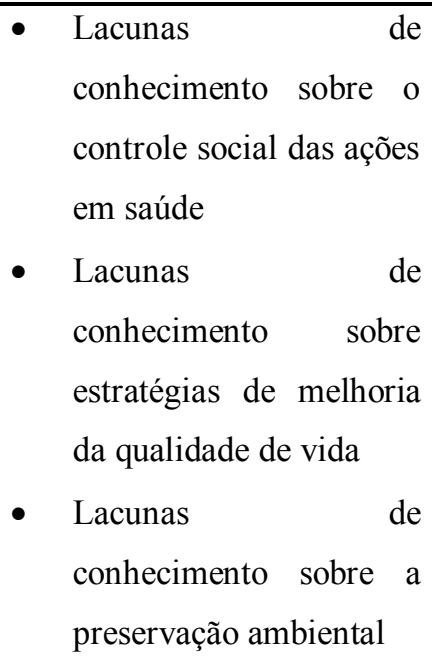 & - Conjunto de munícipes \\
\hline População rural assentada & 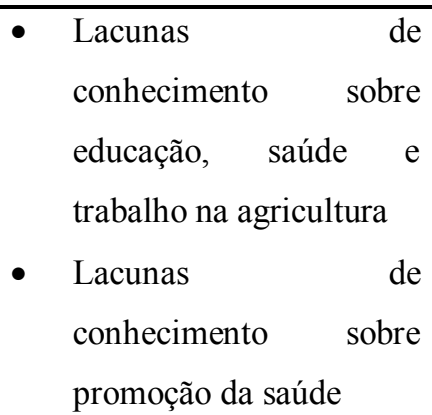 & $\begin{array}{ll}\text { - } & \text { Comunidade } \\
\text { assentada } & \text { rural } \\
\text { - Comunidade } & \text { rural } \\
& \\
\text { assentada } & \end{array}$ \\
\hline População semi-rural & $\begin{array}{l}\text { - Lacunas de } \\
\text { conhecimento sobre } \\
\text { crescimento infantil e } \\
\text { cidadania }\end{array}$ & - Comunidade semi-rural \\
\hline Transeuntes & $\begin{array}{llr}\text { - } & \text { Lacunas } & \mathrm{de} \\
\text { conhecimento sobre } & \mathrm{a} \\
& \text { importância do lúdico }\end{array}$ & - Ruas \\
\hline $\begin{array}{l}\text { Ouvintes de uma rádio e } \\
\text { leitores de um jornal }\end{array}$ & 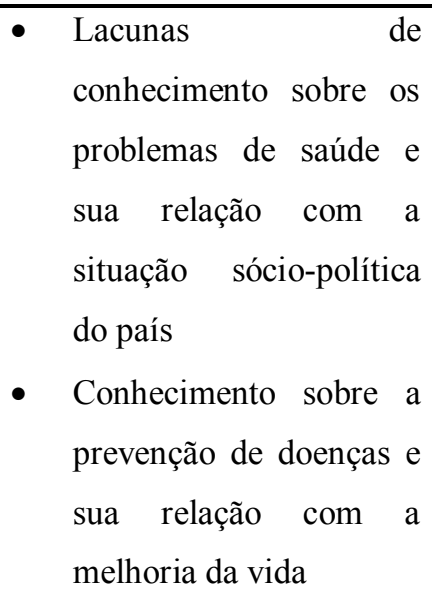 & - $\quad$ Conjunto de indivíduos \\
\hline
\end{tabular}


Figura XI - Trabalhadores: temas e âmbito de atuação grupal

\begin{tabular}{|c|c|c|}
\hline \multicolumn{3}{|c|}{ Objeto } \\
\hline Sujeito & Tema & Âmbito de atuação grupal \\
\hline Bancários & $\begin{array}{llr}\text { - } & \text { Lacunas } & \text { de } \\
\text { conhecimento } & \text { sobre } \\
& \text { saúde e doença } & \end{array}$ & - Conjunto de indivíduos \\
\hline $\begin{array}{l}\text { Funcionários de uma } \\
\text { universidade pública }\end{array}$ & $\begin{array}{lr}\text { - Lacunas } & \text { de } \\
\text { conhecimento } & \text { sobre } \\
\text { estratégias } & \text { de } \\
\text { autocuidado } & \end{array}$ & - Conjunto de indivíduos \\
\hline Agentes locais de saúde & $\begin{array}{l}\text { - Lacunas de } \\
\text { conhecimento sobre a } \\
\text { atuação comunitária de } \\
\text { promoção e prevenção à } \\
\text { saúde }\end{array}$ & - Conjunto de indivíduos \\
\hline Conselheiros locais de saúde & $\begin{array}{lr}\text { - } & \text { dacunas } \\
\text { conhecimento } & \text { sobre } \\
\text { cidadania } & \end{array}$ & $\begin{array}{l}\text { - Conselhos locais de } \\
\text { saúde }\end{array}$ \\
\hline Educadoras infantis & $\begin{array}{lr}\text { - } & \text { Lacunas } \\
\text { conhecimento sobre a } & \text { a } \\
\text { importância } & \text { de } \\
\text { atividades lúdicas } & \\
\text { - } & \text { Lacunas de } \\
\text { conhecimento sobre } & \text { estratégias de resolução } \\
\text { dos problemas de saúde } & \\
\text { das crianças }\end{array}$ & $\begin{array}{l}\text { Pré-escola pública } \\
\text { - Creche conveniada }\end{array}$ \\
\hline
\end{tabular}

\subsubsection{Os meios e instrumentos do trabalho educativo em saúde}

Os meios e instrumentos foram apreendidos no material empírico estudado através dos seguintes indicadores: o espaço físico, em que o agente concretiza o processo de trabalho educativo; os recursos didáticos utilizados, que demonstram viabilidade de transformação concreta do objeto-sujeito no processo educativo; a freqüência dos encontros, que viabiliza a transformação do tema pelos sujeitos; a concepção de educação em saúde que permite vislumbrar o saber operante/instrumental dos agentes no processo de trabalho educativo. 
Observa-se assim na Tabela 12 que $42(91,3 \%)$ relatos mencionaram o espaço físico em que foi realizado o trabalho educativo e em $4(8,7 \%)$ relatos essa informação não foi encontrada.

Tabela 12 - Relatos de experiência educativa dos enfermeiros brasileiros quanto a identificação do espaço físico em que foi realizado o trabalho educativo, no período 1988-2005

\begin{tabular}{ccc}
\hline Identificação do espaço físico & $\mathbf{N}$ & $\mathbf{\%}$ \\
\hline Sim & 42 & 91,3 \\
Não & 04 & 8,7 \\
\hline Total & $\mathbf{4 6}$ & $\mathbf{1 0 0 , 0}$ \\
\hline
\end{tabular}

Por sua vez, os dados da Tabela 13 indicam que $26(56,5 \%)$ relatos informaram que os trabalhos educativos foram realizados em instituições públicas, $16(34,8 \%)$ em instituições privadas e em $4(8,7)$ relatos essa informação não existia.

Tabela 13 - Relatos de experiência educativa dos enfermeiros brasileiros quanto ao caráter do local em que foi realizado o trabalho educativo, no período 1988-2005

\begin{tabular}{ccc}
\hline Caráter do local em que foi realizada a atividade educativa & N & $\mathbf{\%}$ \\
\hline UBS, escola e universidade pública & 26 & 56,5 \\
Creche conveniada, ONG, Centro comunitário, instituição religiosa, \\
assentamento, rádio de uma universidade privada e agência bancária \\
Sem informação & 16 & 34,8 \\
Total & 04 & 8,7 \\
\hline
\end{tabular}

Quanto à freqüência do trabalho educativo, na Tabela 14 nota-se que 5 $(10,9 \%)$ deles foram constituídos por um encontro, $4(8,7 \%)$ por dois a três encontros, $27(58,7 \%)$ por quatro a sete encontros e em $10(21,7 \%)$ relatos essa informação não foi encontrada. 
Tabela 14 - Relatos de experiência educativa dos enfermeiros brasileiros quanto a freqüência dos encontros do trabalho educativo, no período 1988-2005

\begin{tabular}{ccc}
\hline Freqüência dos encontros do trabalho educativo & $\mathbf{N}$ & $\mathbf{\%}$ \\
\hline Um encontro & 5 & 10,9 \\
Dois a três encontros & 4 & 8,7 \\
Quatro a sete encontros & 27 & 58,7 \\
Sem informação & 10 & 21,7 \\
\hline Total & $\mathbf{4 6}$ & $\mathbf{1 0 0 , 0}$ \\
\hline
\end{tabular}

A presença da concepção de educação em saúde que, conforme o referencial teórico-metodológico tomado neste trabalho, direciona o agente - num "saber operante/instrumental" - para a transmissão do conteúdo e a transformação do objeto-sujeito do processo de trabalho educativo em saúde pode ser visualizada na tabela 15 . Nota-se que 27 relatos $(58,7 \%)$ apresentaram a concepção de educação em saúde e que em 19 (41,3\%) essa informação não existia.

Tabela 15 - Relatos de experiência educativa dos enfermeiros brasileiros quanto a presença da concepção de educação em saúde constituinte do "saber operante" dos trabalhos educativos, no período 1988-2003

\begin{tabular}{c|cc}
\hline Presença da concepção constituinte do "saber operante" & N & \% \\
\hline Educação em saúde & 27 & 58,7 \\
Sem informação & 19 & 41,3 \\
\hline Total & $\mathbf{4 6}$ & $\mathbf{1 0 0 , 0}$ \\
\hline
\end{tabular}

Em relação aos recursos didáticos utilizados nos trabalhos educativos, observa-se na Tabela 16 que $27(58,7 \%)$ trabalhos utilizaram oficinas, peças de teatro, jogos, atividades recreativas e outros que estimulavam a participação ativa dos sujeitos e que $19(41,3 \%)$ relatos usaram palestras, cartazes, consultas de enfermagem (CE), curso em fascículos, programa de rádio e/ou vídeos que por sua vez incentivavam sua participação passiva. 
Tabela 16 - Relatos de experiência educativa dos enfermeiros brasileiros quanto ao tipo de recursos didáticos utilizados nos trabalhos educativos, segundo o período 1988-2003

\begin{tabular}{ccc}
\hline Tipos de recursos didáticos & N & \% \\
\hline Oficinas, peças de teatro, jogos, atividades recreativas e outros & 27 & 58,7 \\
Palestras, cartazes, CE, curso em fascículos, programa de rádio e/ou vídeos & 19 & 41,3 \\
\hline Total & $\mathbf{4 6}$ & $\mathbf{1 0 0 , 0}$ \\
\hline
\end{tabular}

\subsubsection{A finalidade do trabalho educativo em saúde}

A finalidade do trabalho educativo foi apreendida através de quatro indicadores: o tipo de avaliação (processo ou resultado), a meta a ser alcançada, a articulação entre o "saber fazer" e o "saber operante" e a identificação dos avaliados.

A Tabela 17 indica que $26(56,6 \%)$ relatos apresentaram avaliações de processo, 10 (21,7\%) avaliações de resultados e que 10 (21,7\%) não apresentaram a avaliação do trabalho educativo. Apesar da importância das avaliações de processo, preocupa o fato de que os relatos explicitam pouco a presença da avaliação de resultados, seja a curto, médio ou longo prazos.

Tabela 17 - Relatos de experiência educativa dos enfermeiros brasileiros quanto a identificação do tipo de avaliação empregado pelos trabalhos educativos, segundo o período 1988-2003

\begin{tabular}{ccc}
\hline Tipo de avaliação & N & \% \\
\hline Processo & 26 & 56,6 \\
Resultado & 10 & 21,7 \\
Sem informação & 10 & 21,7 \\
\hline Total & $\mathbf{4 6}$ & $\mathbf{1 0 0 , 0}$ \\
\hline
\end{tabular}

A meta a ser alcançada foi explicitada de acordo com o objeto e pode ser acompanhada no anexo IV. Sinteticamente, têm-se os seguintes resultados (Tabela 18): a mudança de comportamento para um comportamento considerado saudável em 
18 relatos $(39,1 \%)$, o controle e a prevenção de doenças em 12 relatos $(26 \%)$, a discussão sobre os fatores causais das doenças em 10 relatos $(21,7 \%)$, a melhoria das condições de vida na casa/bairro ou outro espaço do âmbito do consumo em 5 relatos $(10,8 \%)$ e a melhoria das condições de trabalho em 1 relato $(2,2 \%)$.

Tabela 18 - Relatos de experiência educativa dos enfermeiros brasileiros quanto a meta a ser alcançada nos trabalhos educativos, segundo o período 1988-2003

\begin{tabular}{llc}
\hline \multicolumn{1}{c}{ Meta a ser alcançada } & N & \% \\
\hline Comportamento saudável & 18 & 39,1 \\
Controle e prevenção de doenças & 12 & 26,0 \\
Discussão sobre os fatores causais das doenças & 10 & 21,7 \\
Melhoria das condições de vida & 05 & 10,8 \\
Melhoria das condições de trabalho & 01 & 2,2 \\
\hline \multicolumn{1}{c}{ Total } & $\mathbf{4 6}$ & $\mathbf{1 0 0 , 0}$ \\
\hline
\end{tabular}

A presença da articulação entre as concepções de saúde e de educação constituintes do "saber fazer" na captura do objeto de trabalho e da concepção de educação em saúde que é parte do "saber operante" dos instrumentos no processo de trabalho educativo em saúde pode ser visto na Tabela 19. Nota-se que entre os 46 relatos analisados, apenas $16(34,8 \%)$ apresentam as concepções sobre saúde, educação e educação em saúde, 07 (15,2\%) articulam educação e educação em saúde, 04 (8,7) saúde e educação em saúde, 17 (36,9\%) não fazem a articulação entre os saberes e 02 (4,4\%) não continham nenhuma informação.

Tabela 19 - Relatos de experiência educativa dos enfermeiros brasileiros quanto a presença da articulação entre as concepções constituintes do "saber fazer" e do "saber operante" dos trabalhos educativos, segundo o período 1988-2003

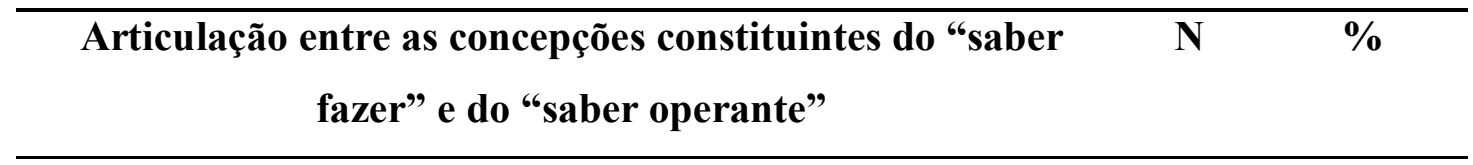


Educação e educação em saúde

15,2

Saúde e educação em saúde

Sem articulação

$17 \quad 36,9$

Sem informação

02

Os dados da Tabela 20 evidenciam que entre os 36 relatos que continham a avaliação do trabalho educativo, $3(6,5 \%)$ avaliados eram os agentes, $13(28,3 \%)$ os sujeitos e $20(43,5 \%)$ os agentes e os sujeitos.

Tabela 20 - Relatos de experiência educativa dos enfermeiros brasileiros quanto a identificação dos avaliados dos trabalhos educativos, segundo o período 1988-2003

\begin{tabular}{ccc}
\hline Identificação dos avaliados & $\mathbf{N}$ & $\mathbf{\%}$ \\
\hline Agentes & 3 & 6,5 \\
Sujeitos & 13 & 28,3 \\
Agentes e sujeitos & 20 & 43,5 \\
Sem informação & 10 & 21,7 \\
\hline Total & $\mathbf{4 6}$ & $\mathbf{1 0 0 , 0}$ \\
\hline
\end{tabular}




\section{DISCUSSÃO}

\subsection{Caracterização geral dos relatos de experiência educativa dos enfermeiros brasileiros no período entre 1988-2003}

Para a UIPES (1998a), a utilização de práticas educativas em saúde possibilita a construção ou a atualização periódica de diagnósticos de necessidades educativas junto da população, dos serviços e das universidades no intuito de viabilizar a concretização de novas práticas de participação e de controle social para consolidar o SUS.

Os resultados encontrados nesta pesquisa apontam na direção de que a enfermagem vem gradativamente esforçando-se por formular e concretizar novas práticas educativas em saúde, uma vez que há um incremento de publicações a partir de 1988 que favorecem a integração regular da prática educativa à ação de saúde e a discussão de estratégias para a integração das práticas pedagógicas ou educativas nas ações de saúde (UIPESa, 1998:7).

Embora sob um olhar inadvertido possa ser considerado um detalhe, chama a atenção o fato da maioria dos relatos não apresentar informações consistentes sobre a localização geográfica dos sujeitos do processo de trabalho educativo em saúde.

Isso pode ser reflexo de uma certa desatenção quanto à contextualização, elemento que circunstancia de maneira fundamental a compreensão da realidade e portanto dos discursos provenientes dos autores que produzem os referidos textos (Pêcheux, 1990; Fiorin, 1990).

Assim, essa aparente desatenção com uma parcela do contexto do trabalho educativo - o espaço geo-social - pode ser melhor compreendida pelo contexto de recente constituição da Enfermagem no âmbito da pesquisa e das publicações científicas em geral, uma vez que, os cursos de pós-graduação stricto sensu mestrado em Enfermagem foram inicialmente implantados no Brasil a partir de 1972 e o doutorado em Enfermagem a partir de 1982 (Augusto, 1990; Collet, Schneider e Correa, 2000).

Antes disso, como forma de constituição do campo da enfermagem, priorizaram-se as pesquisas que apoiadas por métodos científicos legitimavam a 
assistência e o ensino já que, historicamente a enfermagem auxiliava as pesquisas médicas, mas não desenvolvia suas próprias pesquisas (Augusto, 1990; Cianciarullo, Salzano, 1991).

Até então, as publicações consistiam em trabalhos descritivos, relatos da prática, opiniões pessoais, traduções de artigos norte-americanos e empréstimo de conhecimentos de outras disciplinas para fundamentar a prática de enfermagem, com conteúdos teórico-metodológicos assistemáticos (Collet, Schneider, Correa, 2000:76). Talvez por isso, uma parte considerável das publicações dos relatos de experiência seja relevada pelas revistas de enfermagem.

Numa primeira aproximação, tende-se a crer que os relatos de experiência educativa sejam publicados na sua maioria por enfermeiros vinculados aos serviços de saúde. Contudo, os resultados encontrados indicam que a participação dos enfermeiros da rede básica de serviços de saúde nas publicações equipara-se a dos alunos de graduação em enfermagem.

Isso indica algo já mencionado por Collet, Schneider e Correa (2000) ao refletir sobre a organização e o desenvolvimento da pesquisa em enfermagem no Brasil, já que a articulação da pesquisa com o ensino de graduação e com os trabalhadores dos serviços de saúde continua sendo um dos desafios enfrentados na área.

Os relatos foram quase majoritariamente assinados por docentes de enfermagem em parceria com alunos de pós-graduação de instituições públicas, o que faz supor que o tema da educação em saúde não constitui interesse das universidades privadas.

\subsection{Elementos constituintes do processo de trabalho educativo em saúde}

Para atingir a práxis humana - objeto do trabalho educativo em saúde - é imprescindível a participação dos sujeitos e dos múltiplos agentes na apreensão dos temas a serem transformados a fim de que sejam concretamente incorporados no aperfeiçoamento da força de trabalho dos agentes e no cotidiano dos sujeitos. Nesse sentido, a práxis se tornará uma prática fundamentada teoricamente pelos 
temas/conteúdos que serão transformados no processo de trabalho educativo em saúde (Paro, 2002; Gonzaga, 1992a; Saviani, 2005).

Uma vez que, para Konder (2004:1-2),

a construção do conhecimento necessita de desconfiança em relação a si mesma e também de autoconfiança. [Desse modo, a dialética marxista] contribui [para a desconfiança] pela ligação com o conceito de ideologia: a distorção ideológica pode ser tão sutil que (...) não se perceba infiltrar-se no ponto de vista. [E, contribui] para a autoconfiança (...) pela ligação com o conceito de práxis, [já que o sujeito ao realizar alguma atividade] aproveita algum conhecimento ao interferir no mundo, transformando-o e se transformando a si mesmo.

Assim, quando se investigou a participação dos múltiplos agentes do processo de trabalho educativo no planejamento das ações tinha-se em mente essa concretização práxica. Entre os relatos de experiência analisados, a participação dos docentes no planejamento do trabalho educativo em saúde foi marcante. Já a participação dos sujeitos foi bem menor, mas ainda mais restrita foi a participação dos alunos de graduação e dos trabalhadores da rede básica de serviços de saúde. Se por um lado nota-se que cada vez mais vem se chamando o chamado "público-alvo" à participação, por outro, reproduz-se a divisão social do trabalho, consubstanciado na divisão técnica do trabalho, restringindo a participação dos diversos agentes no processo de trabalho educativo.

Nesse sentido, o resultado encontrado nesta pesquisa em relação ao planejamento das ações educativas confirma parte do que UIPES (1998b) encontrou quando diagnosticou as ações educativas em curso no Brasil, uma vez que o projeto educativo tende a ser ajustado às necessidades da população-alvo, (...) segundo a percepção dos técnicos (profissionais da saúde, professores, chefias e outros), sem envolver diretamente os sujeitos do processo educativo e com pouca parceria entre a universidade/serviços/população.

Conforme Mendes Gonçalves (1992:40), 
a técnica não existe isolada de sua apropriação diferenciada na reprodução das diferenças de classe, e o controle dos momentos "mais intelectuais" do trabalho garante o poder sobre o conjunto do processo (...) [reproduzindo] o mesmo tipo de dinâmica geral característica da reprodução social, acarretando contradições que opõe, de um lado, uma racionalidade puramente técnica, mas abstrata, e de outro lado, a necessidade de reprodução de relações sociais, em si mesma também abstrata.

Nesse sentido, depreende-se que a participação requerida aos sujeitos é aquela necessária à legitimação dos saberes técnicos, que são reconhecidos como os que devem ser incorporados aos sujeitos não-técnicos para operar as modificações comportamentais necessárias ao controle dos "determinantes" do processo saúdedoença. Ou seja, o conhecimento é dos técnicos, mas a ação é dos indivíduos, amparada pelo "saber operante/instrumental" que durante o processo educativo é multiplicado a fim de que indivíduos isolados, não portadores de uma identidade de classe, identifiquem-se com a finalidade do trabalho dos técnicos e dessa forma, aliem-se aos propósitos da Nova Saúde Pública ${ }^{4}$ cujo eixo principal é o projeto da Promoção à Saúde.

Dessa forma, a aparente participação dos sujeitos corre o risco de ser na verdade instrumental para atingir a finalidade de transformar a "necessidade social" a que a atividade educativa deve satisfazer em um produto - sujeito com "necessidade social" satisfeita - que agora responsabiliza-se quase que integralmente pela satisfação dessa necessidade, uma vez que agora detém o conhecimento.

No caso da Nova Saúde Pública, que vem utilizando amplamente o instrumento da participação - inclusive a partir de autores como Paulo Freire - a transformação do tema será realizada pelos sujeitos, que contarão como instrumento, um "saber operante/instrumental" fragmentado e difuso. Com esse saber, o sujeito pode assumir a responsabilidade por modificar seu ambiente social, mas não detém nem conhecimento, nem mecanismos de poder coletivo para discutir as raízes das

\footnotetext{
${ }^{4}$ O termo foi cunhado a partir de 1990, quando a OPAS promoveu um debate sobre a crise da saúde pública privilegiando a discussão sobre os novos desafios sociais, políticos e culturais, o esgotamento do paradigma biomédico, a mudança do perfil epidemiológico da população e a reflexão sobre os conceitos, teorias, metodologias, elementos explicativos, determinantes estruturais, repercussões
} 
desigualdades sociais, que estão na base dos problemas de saúde para transformar esses processos (Carvalho, 2004b).

Nesse caso, o sujeito não é co-produtor do processo educativo porque sua participação no processo é apenas e tão somente instrumental, o que significa dizer que o sujeito está sendo desgastado durante o processo, sentindo-se ao final culpado por não atingir melhores padrões de saúde e impossibilitado de acionar os serviços públicos de saúde, uma vez que a satisfação de sua necessidade de saúde é de sua competência (autonomia para controlar o diabetes e a pressão arterial; exercer a sexualidade com responsabilidade, entre outros) e de âmbito íntimo, privado.

De fato, de acordo com Marilena Chauí isso é consistente com a ideologia neoliberal - projeto econômico, político e ideológico da pós-modernidade - que apregoa o alargamento do espaço privado e o encolhimento do espaço público (Calipo, 2002) e isto se manifesta no "retorno do individualismo", (...) que destrói a noção de responsabilidade coletiva e torna o indivíduo o único responsável pela reprodução da vida social (Bordieu, 1998: 15-16).

A conseqüência disso pretende ser um dito empowerment psicológico que põe o sujeito em situação de constrangimento para acessar os serviços públicos. Essa noção vem sendo aliada do neoliberalismo nos Estados Unidos e afirma a importância da autonomia e da diminuição da dependência de instituições macrossociais (Carvalho, 2004b).

O sujeito será encarado como co-produtor do processo educativo quando tão somente for incorporado como produtor-participante do "saber fazer" dos agentes concepção de saúde e de educação - a fim de objetualizar o ideário sobre o tema que será transformado com a atividade educativa. Ou seja, para que o processo se desenvolva com a participação real (co-produção), o saber a ser incorporado na ação (práxis) deverá ser a somatória entre o "saber operante/instrumental" dos agentes concepção de educação em saúde sobre o tema a ser apreendido pelos sujeitos - e, o "saber fazer" - concepção de saúde e de educação - tanto dos agentes quanto dos sujeitos, que articula todas as fases do processo.

De acordo com Lessa (2001) o momento singularizante não é suficiente para que ocorra o processo educativo, ou qualquer processo de transformação humana, é preciso um outro momento que articule todas as fases do processo. Isto produz um 
conhecimento totalizante sobre o processo de transformação em pauta. Tal conhecimento é radicalmente diferente do conhecimento necessário à consecução de uma parte do processo - o "saber operante/instrumental".

Nesse sentido, assegura-se

a experiência subjetiva do empowerment psicológico e a [realidade objetiva] (...) do empowerment comunitário, [já que os indivíduos tornam-se capazes de] reconfigurar o contexto social no qual vivem e que este movimento tem conseqüencias positivas para a saúde uma vez que possibilita o desenvolvimento de competências para participar da vida em sociedade, [incluindo habilidades, mas também] um pensamento reflexivo que qualifica a ação política (Carvalho, 2004b:35).

Desse modo, o conhecimento sincrético do educando no processo educativo é transformado em um saber sintético, necessário à práxis criativa (Saviani, 2003). Entretanto, o "saber operante/instrumental" é suficiente na divisão social do trabalho para a reprodução das relações de produção. Ou seja, a participação dos sujeitos no processo educativo em saúde realizado nos moldes na Nova Saúde Pública tende a fortalecer a divisão de classes e, portanto as desigualdades sociais e em saúde.

Por seu turno, os trabalhadores de enfermagem têm historicamente graus de formação diferenciados e, na divisão do trabalho, garantem ao enfermeiro, o papel de detentor do saber e controlador do processo de trabalho da enfermagem, cabendo aos demais trabalhadores de enfermagem o papel de executores de tarefas delegadas. Essa lógica de separação entre a concepção e a execução do trabalho e de controle gerencial das tarefas parcelares corresponde à divisão do trabalho no modo de produção capitalista, vigente na época da organização profissional da enfermagem (Pires, 1998).

Os resultados mostraram que a assistência não tem sido a necessidade geradora do trabalho educativo, mas o ensino. Uma primeira incursão analítica pelos resultados pode levar a crer que então o ensino do trabalho educativo em saúde está se efetivando. No entanto, o agente-docente de enfermagem foi incumbido, na maior parte das vezes, do trabalho intelectual, nem sempre chegando à completude do processo educativo, uma vez que não participou do trabalho em si; o agente-aluno de 
graduação em enfermagem que implementou o processo possuía uma idéia operativa do que seria atingido com o trabalho, na maior parte das vezes, não participando da elaboração. O agente-aluno de pós-graduação em enfermagem parece ser o único que tem possibilidade de participar tanto do momento da ideação quanto do momento da concretização, constituindo-se uma exceção por encontrar-se em um lugar provisório, o de educador e educando.

Vale aqui retomar Paro (2002), para quem no processo de trabalho pedagógico está envolvido também um outro "tipo" de saber que não se separa do momento da produção. Trata-se do saber enquanto saber "que se passa", ou seja, do saber historicamente produzido que é conteúdo/tema de apropriação pelo educando. Este saber possui características de "objeto de trabalho", já que é incorporado no produto e não pode, por isso, deixar de estar presente no ato de produção.

Dessa forma, pode se apreender com os relatos que ocorreu uma certa divisão pormenorizada do trabalho educativo, tendo o docente e o aluno de pós-graduação como os que trabalham "o saber fazer" e os alunos de graduação e de pós-graduação em enfermagem como os agentes que trabalham "o saber que se passa". Nesse sentido, apreende-se que o processo de trabalho do ensino não foi utilizado em toda a sua potencialidade para o aperfeiçoamento da força de trabalho dos alunos de graduação, mas de fato o foi para os alunos de pós-graduação.

Por sua vez, estes alunos de graduação serão os futuros trabalhadores dos serviços que também não participarão - e tudo indica que não participaram - do momento subjetivo da atividade. Os docentes não compartilharam, como os alunos de pós-graduação, do momento da concretização da ideação que têm sobre o que será transformado com o processo educativo empreendido com a população. Talvez isso justifique porque o processo de trabalho da assistência gerou poucos processos de trabalho educativo entre os relatos de experiência educativa analisados.

Os resultados encontrados nesta pesquisa indicam que as universidades poucas vezes se articulam com os trabalhadores da rede básica de serviços de saúde para o planejamento e execução dos processos de trabalho educativo em saúde.

Os trabalhadores dos serviços, por sua vez, subordinados formalmente à reprodução social dos saberes implicados nos processos de trabalho do processo de produção dos serviços de saúde, não conseguem se articular facilmente nem com as distintas práticas sociais em saúde e muito menos com as universidades para transformar o trabalho rotineiro em "trabalho vivo" potencializador de mudanças. 
E, nesse sentido os conhecimentos científicos e as aplicações técnicas que legitimam suas práticas sociais,

cercam os técnicos ou os profissionais da autoridade contra a qual nenhum outro saber pode recorrer. Essa cultura (...) vivida espontaneamente, de modo não consciente, como a "posse de conhecimentos, habilidades e gostos específicos" [...] entranhada tanto nas mentalidades quanto nos procedimentos rotineiros, adquire o caráter de uma tradição que resiste à mudança e procura impor-se mediante o recurso da autoridade - ou seja, autoritariamente (Stotz e Araújo, 2004:15).

Por seu turno, os docentes também subordinados formalmente à produção/reprodução dos saberes, enfrentam barreiras para promover essa articulação uma vez que, tendem a ser submissos às demandas da burocracia acadêmica (Salum, Queiroz e Soares, 1999), servindo ao ideário da universidade operacional (Chauí, 1999). Assim, a gerência do trabalho acadêmico consubstanciase como espaço de afirmação do poder (e nem sempre de autoridade), mais valorizados do que os espaços dos laboratórios, dos serviços e das salas de aula (Salum, Queiroz e Soares, 1999).

A apreensão dos objetos nos relatos educativos analisados a partir dos sujeitos, temas e âmbito de atuação grupal, permite afirmar que a maioria dos conteúdos a serem apreendidos ao final dos processos de trabalho educativo em saúde

[pressupõe] que as pessoas não tem uma cultura da saúde, não vêm a saúde como um bem desejável e precisam ser conscientizadas da sua importância. Há subjacente, uma visão de mundo que nega radicalmente a cultura e o saber popular (Stotz e Araújo, 2004:12).

Os principais conteúdos - DST/Aids, campanhas preventivas, saúde do adolescente e da criança - explicitados nos resultados encontrados nesta pesquisa corroboram com as prioridades governamentais e com o planejamento normativo estatal da ação educativa em saúde. Dado que a prestação de serviços de atenção à 
saúde tende a se restringir sob orientação das políticas de ajuste para a relação custobenefício (anos de vida saudável perdidos por mortalidade prematura e aqueles perdidos como resultado de incapacidade) e para a definição de um pacote mínimo de serviços clínicos essenciais (Misoczky, 1995).

Ainda para a autora (1995:6), o pacote mínimo do Estado ficaria restrito: ao cuidado a crianças doentes, planejamento familiar, atenção à gestação e ao parto, $e$ tratamento para tuberculose e DSTs [...] além de doenças crônicas e degenerativas.

De fato, Campos (2004:160) ao analisar as necessidades de saúde expressas pela sociedade civil (os moradores) e pelo Estado (os trabalhadores de saúde) encontra resultados parecidos, já que

as práticas (...) [em saúde] prescindem do conhecimento das características da população, uma vez que os programas vêm prontos, pré-determinados pelo Ministério da Saúde e pela Secretaria Municipal da Saúde, numa clara demonstração de que o Estado prevê ações focalizadas para grupos específicos.

Caminhando nessa direção, a explicitação dos temas - parte importante da matéria prima do objeto de trabalho dos processos educativos em saúde - permite, segundo Gonzaga (1992b), revelar o grau de desenvolvimento social alcançado por determinada sociedade e quais as possibilidades que foram oferecidas para os homens desenvolverem suas potencialidades humanas na prática histórica e social da educação em saúde.

Deste modo, os conteúdos a serem apreendidos pelos sujeitos nos relatos educativos analisados nesta pesquisa tendem a reduzir a amplitude das ações de saúde, propostas pela Norma Operacional Básica do Sistema Único de Saúde 01/96 e pela Portaria $\mathrm{n}^{\mathrm{o}} 3.925$, de 13 de novembro de 1998, que aprova o Manual para a Organização da Atenção Básica no Sistema Único de Saúde (Calipo, 2002).

Uma vez que,

a redefinição do modelo de saúde se dá, (...) pela divisão em dois grandes grupos de ações e atividades de assistência: o primeiro dirigido à toda a população e o segundo restrito aos denominados grupos especificos [se resumindo a algumas ações programáticas:] 
crianças menores de 5 anos - aleitamento materno, imunização, nutrição, controle de doenças respiratórias agudas, combate às doenças diarréicas. Até os 14 anos as ações são dirigidas ao controle do crescimento e desenvolvimento e prevenção de cáries dentárias. Às mulheres as ações são dirigidas ao pré-natal, puerpério e prevenção de câncer de mama e cérvico uterino. Ao homem adulto ações básicas aos acidentados e portadores de agravos causados pelo trabalho e notificação dos agravos e riscos relacionados ao trabalho. Os programas são os dirigidos à tuberculose, hanseniase, hipertensão arterial sistêmica e diabete mellitus. Aos idosos são previstas ações para prevenção de quedas e incentivo aos grupos de auto-ajuda. E as novas tecnologias dirigidas a toda a população, limitam-se a informações $e$ orientações educativas e, como intervenção, as vigilâncias epidemiológica e sanitária, contrariando a universalidade do SUS, presente na Constituição e na Lei $n^{\circ}$ 8.080/90 (Calipo, 2002:111-2).

Assim, é possível dizer que a sociedade brasileira compõe trabalhos educativos na rede básica de serviços de saúde cujo desenvolvimento reprime as possibilidades do homem genérico de exercer sua criatividade e liberdade porque tem recortado objetos pontuais - agravos, ambientes sociais que interferem no comportamento individual que por sua vez afeta a saúde -, tomados a partir de uma visão de mundo que conceitua um homem como um ser individual, funcionando como um sistema de órgãos em perfeita harmonia, que faz parte de uma sociedade homogênea, sem classes sociais. Em suma, uma visão funcionalista (García, 1983), que reforça a hegemonia do ideário neoliberal (Carvalho, 2004a).

Desse modo, as práticas educativas que buscam contribuir para a formação da "consciência sanitária", por meio de um esforço pedagógico sistemático e permanente, envolverão técnicas focais e de marketing social que tem como objetivo a manutenção da harmonia social e de uma relação saudável entre indivíduo e o seu meio externo (Carvalho, 2004a) já que, a saúde deixa de ser um estado para se tornar um "projeto" (Sabroza, 2004; Stotz e Araújo, 2004). Projeto este que define-se em cada nação, ou cada grupo social, de acordo com sua possibilidade econômica, técnica, política e cultural (Stotz e Araújo, 2004:12). 
Para Vargas e Soares (1997), as práticas de capacitação em saúde não podem se reduzir à simples transferência de conhecimentos e à assimilação de destrezas motoras ou de novas técnicas. O processo educativo em saúde pode possibilitar a síntese entre o saber popular, a ciência e a tecnologia moderna quando parte da vivência dos próprios participantes, a partir de uma visão de mundo que os perceba como sujeitos no processo pedagógico.

A reflexão crítica que permitirá essa síntese se dará na medida em que são expostas as contradições existentes na realidade de saúde, articuladas ao contexto das relações sociais da coletividade a fim de buscar os pontos de fragilidade que serão as possibilidades reais de se intervir nessa realidade. A aparente inexistência de elementos frágeis pode ser enganosa, por isso é fundamental a busca exaustiva e minuciosa da historicidade dos processos que constituirão a qualidade do tema objeto de trabalho educativo. A aplicação do conceito de práxis (criadora e reflexiva) torna-se, portanto, essencial nessa intervenção (Vàzquez, 1977; Gonzaga, 1992b; Egry, 1996).

Uma vez que a essência humana é historicamente determinada pela reprodução social, são os homens que fazem sua própria história ainda que em circunstâncias que não escolheram e, portanto, não há uma essência humana a histórica que não possa ser subvertida pelos atos humanos (Lessa, 1996).

Para Mendes Gonçalves (1992), o esquadrinhamento e o esquartejamento da natureza contido na delimitação dos objetos de trabalho constitui a base ontológica para a diferenciação histórica da razão humana e, ao mesmo tempo, para seus conteúdos objetivados, o conhecimento acumulado.

Mais que repassar informações e induzir determinados comportamentos é necessário apoiar os indivíduos para que realizem suas próprias análises e tomem as decisões que considerem corretas, desenvolvendo a consciência crítica e a capacidade de intervenção sobre a realidade (Carvalho, 2004a). Uma vez que, $a$ responsabilização das pessoas pelas suas condições sanitárias é condizente, isto sim, com as (...) políticas de ajuste macroeconômico (Stotz e Araújo, 2004:12).

Vasconcelos (1997:20) ao refletir sobre os espaços educativos na rede básica de serviços de saúde afirma que

educar para a saúde é ajudar na busca da compreensão das raízes dos problemas e de suas soluções [...] e que o saber popular, antes 
de ser um saber atrasado, é um saber bastante elaborado, com ricas estratégias de sobrevivência e com grande capacidade de explicar parte da realidade. Ao mesmo tempo (...) o saber (...) dos técnicos está encharcado dos interesses das classes dominantes e ainda é muito limitado para explicar toda a variedade da realidade. Assim só cabe [compreende-la como um processo baseado] no diálogo, ou seja, na troca de saberes.

Assim,

o papel dos "empoderadores" pertencentes aos serviços públicos é de estabelecer uma mediação entre as demandas dos grupos de pessoas "pobres" ou "excluídas" de poder e os interesses de grupos situados em posições de poder na sociedade. Ao desempenhar este papel, os "empoderadores" assumem a tarefa de reatar os fragmentos de vidas que perderam sentido social $e$ tornam-se eles próprios, os referentes para a reconstrução dessas identidades sociais (Stotz e Araújo, 2004:14).

Deste modo, em síntese, a proposição assumida pelo referencial teórico desta pesquisa sugere a captura processo de trabalho educativo em saúde a partir da seguinte proposição: 
Figura XII - Elementos constituintes do objeto do processo de trabalho educativo em saúde

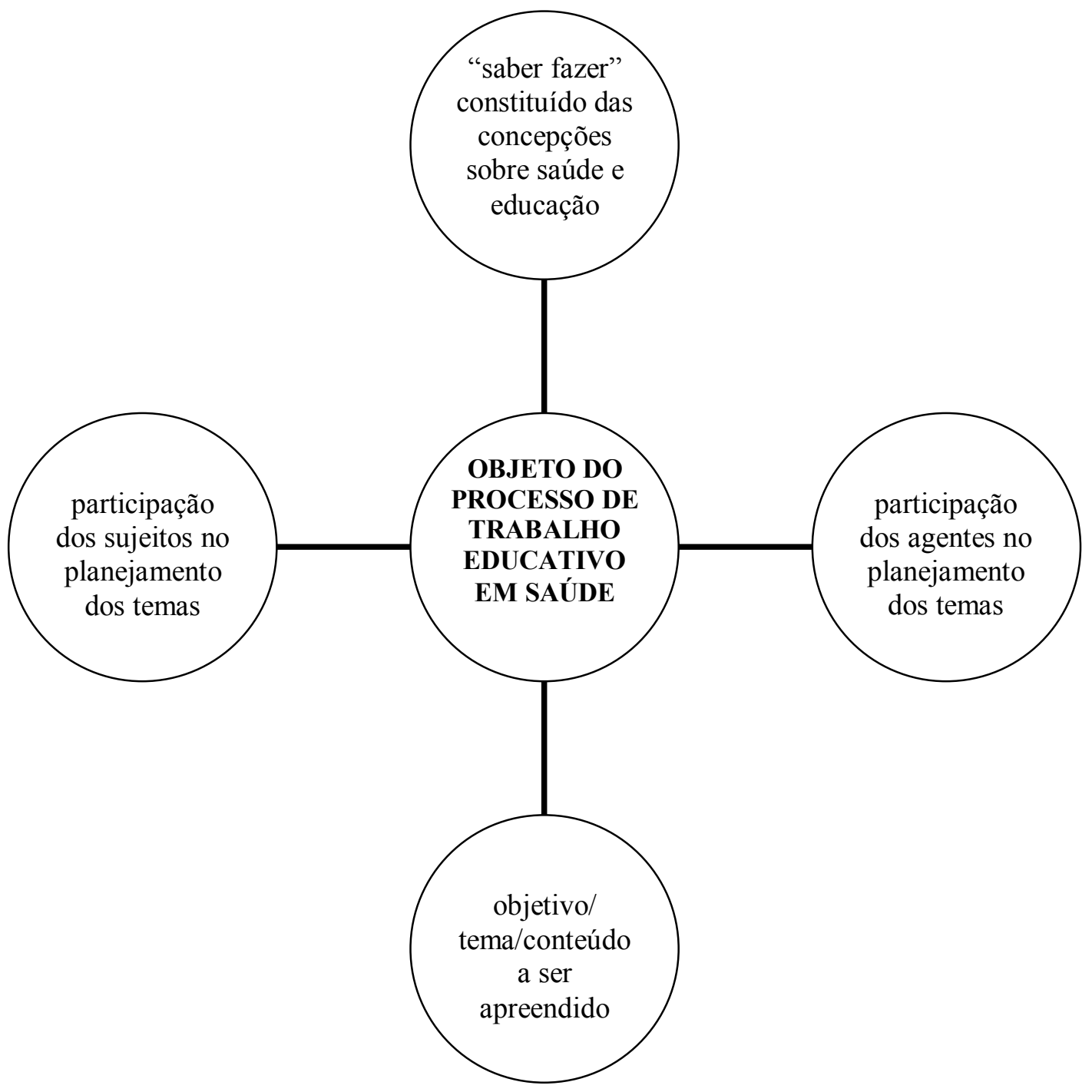

E caminhando nessa direção, os resultados encontrados nesta pesquisa concernentes aos meios e instrumentos do processo de trabalho educativo mostram uma tendência a utilização de instrumentos que viabilizam a participação ativa do sujeito no processo educativo, em conformidade com os resultados que indicaram a requisição de participação no planejamento dos temas das atividades educativas. A utilização de recursos para efetivação de uma participação ativa é maior do que a de recursos que proporcionam uma participação passiva.

Isso facilita a potencialização do produto subjetivo (antevisto) em produto objetivado (concretizado) com a condição de que a prossecução do processo esteja 
articulada e encadeada desde o momento do planejamento do trabalho educativo, já que sua aplicação isolada não garante a participação nem a incorporação do tema pelos sujeitos.

Conforme visto anteriormente essa condição não está sendo cumprida, uma vez que se mantém a divisão entre trabalho intelectual e manual ao

\begin{abstract}
se objetivar (...) a natureza parcialmente subjetiva da teoria educativa na esfera da ação imediata [por meio da] capacidade humana de interpor mediações à prática, [abstraindo] da reprodução reiterativa da espécie um "excedente intelectual" que fundamenta ontologicamente a gênese do trabalho e da linguagem e, portanto, o homem, como realidade histórica e social (Mendes Gonçalves, 1991:350).
\end{abstract}

Do mesmo modo, o processo de trabalho educativo em saúde assume, como na "pedagogia da fábrica", as características do "saber operante/instrumental":

Este aprendizado, pelo seu próprio caráter fragmentário, não possibilita ao trabalhador a elaboração científica de sua prática, reproduzindo as condições de sua dominação (...). Para os destinados às funções de planejamento e controle, o ensino do trabalho se faz por meio da apreensão sistematizada do conteúdo científico do trabalho, em níveis médios e superiores de escolaridade, porém desvinculado da prática cotidiana do exercício profissional. Contudo, é a aquisição deste saber sistematizado e elaborado cientificamente que permite aos profissionais de níveis mais altos o domínio do trabalhador em favor do capital, pela compreensão de sua prática e do planejamento e controle externo à sua própria ação (Kuenzer, 1986:48).

E é assim que conforme afirmam Stotz e Araújo (2004), a participação popular ativa requerida aos sujeitos é meramente cooperativa (portanto passiva) $e$ não problematizadora (verdadeiramente ativa). 
Nesse sentido, a inclusão da promoção na prática da saúde pública brasileira sofisticou

as estratégias de culpabilização das próprias vítimas da incúria sanitária, além da creditação oficial das teorias do condicionamento comportamental (behaviorismo), absolutamente avessas a qualquer pedagogia da problematização. Exemplos: o advento do "fumante passivo", no controle do tabagismo; e o "vizinho" que fiscaliza a caixa d'água do outro, no controle do Aedes aegypti. Por isso, a educação em saúde virou a vedete dos programas de promoção. Nunca se promoveu tanto a educação sanitária, que é propagada em cursos e treinamentos acríticos (Stotz e Araújo, 2004:13).

A produção de serviços de saúde segue a lógica da divisão social do trabalho capitalista. Do mesmo modo, reproduz-se a divisão entre trabalho manual e intelectual subsumido à divisão social do trabalho. A enfermagem como é uma prática social que historicamente serve aos interesses do capital, termina reproduzindo a divisão social do trabalho (Pires, 1998; Castellanos, 1988; Peduzzi, 2001 Queiroz e Salum, 2000; Almeida e Rocha, 1997).

Aguiar (2001:181) encontrou por referência à qualificação para o trabalho de atendentes de enfermagem a eleição do ensino de procedimentos e de disciplina,

em prejuízo do ensino de conteúdos que propiciem o domínio intelectual dos processos de trabalho: não somente dos meios/instrumentos de trabalho, mas também do objeto e da finalidade do trabalho.

Os profissionais de saúde e, particularmente os trabalhadores de enfermagem, tendem a desvalorizar os momentos educativos da sua prática social, reconhecendo como intervenção somente a realização de procedimentos complexos, que utilizam equipamentos com algum grau de sofisticação tecnológica material (Chiesa e Veríssimo, 2001). 
Como os trabalhadores tendem a focar sua intervenção em procedimentos centrados nos equipamentos, dado que os processos de trabalho são instaurados a partir das possibilidades que os instrumentos oferecem, passam a ser qualificados tecnicamente para operar equipamentos e limitam-se diante da possibilidade de redefinir o objeto a partir de um projeto regido pelas necessidades de saúde (Campos, 2004).

Mesmo os meios e instrumentos, utilizados pelos agentes para transformar a ideação subjetiva - do objeto a ser incorporado pelos sujeitos - em exteriorização objetivada - desse mesmo objeto - de um produto/finalidade no processo de trabalho educativo, e tão valorizados pela enfermagem e pelos relatos analisados, tiveram sua utilização fragmentada.

Falharam no acúmulo de conhecimentos que poderiam aperfeiçoar a transformação do objeto dado que as relações entre sujeito e objeto da ação e do pensamento (...) implicam reconhecer ao sujeito uma natureza objetiva, e ao objeto, enquanto produto, uma natureza parcialmente subjetiva (Mendes Gonçalves, 1990:351).

Resumindo-se então a captura dos meios/instrumentos de trabalho a partir da figura abaixo: 
Figura XIII - Elementos constituintes dos meios/instrumentos do processo de trabalho educativo em saúde

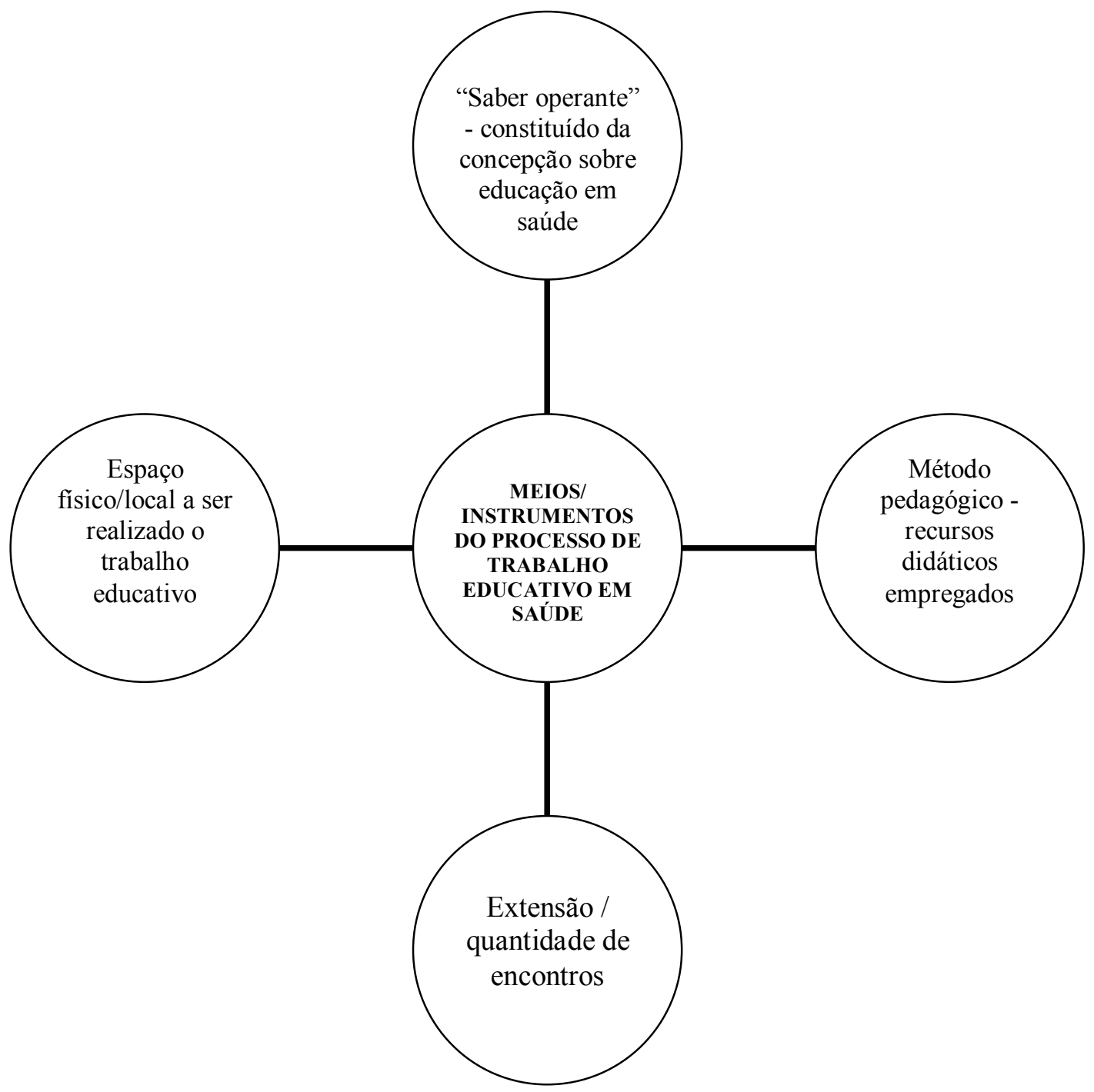

Dessa maneira, a avaliação do processo de trabalho educativo permite perceber a qualidade da transformação que se processou na complexidade desse objeto de trabalho. Nesse sentido, a compreensão do que seja processo é fundamental. Para Lessa (2001), um processo é, necessariamente, a passagem de uma dada situação à outra e para tanto os seus momentos devem ser distintos entre si, senão não teríamos um processo. A singularidade dos momentos do processo não significa, contudo, que não ocorra, também, elementos de continuidade que 
permeiem a todos. Por isso, os elementos que consubstanciam cada momento particular do processo são a mediação indispensável para que o processo se desdobre como tal que é único e portador de todas as determinações passadas que condicionaram sua gênese.

A cada processo de transformação do real a partir de um projeto previamente idealizado na consciência, o trabalho produz objetiva e subjetivamente algo novo. Assim, todo processo de objetivação cria, necessariamente, uma nova situação sóciohistórica, de tal modo que os indivíduos são forçados a novas respostas que devem dar conta da satisfação das novas necessidades a partir das novas possibilidades (Lessa, 2001).

Na própria objetualização de um fragmento da natureza, o poder objetivante dos instrumentos de acordo com Mendes Gonçalves (1992) é um momento essencial uma vez que, por exemplo, um fruto que estivesse em um lugar inacessível, pendendo de um galho muito alto da árvore, continuaria sendo um fruto e continuaria sendo comestível, mas por não ser mais arrancável não seria mais seu objeto de trabalho.

Para Saviani (2005), o trabalho educativo entendido como uma produção nãomaterial, cujo produto não se separa do produtor requer para seu exercício uma materialidade e será essa materialidade que condicionará o seu desenvolvimento. A ação educativa, portanto, desenvolve-se a partir de condições materiais teóricas e em condições materiais práticas.

O fato dos relatos apresentarem um aprimoramento, uma maior precisão, na maneira como socialmente os sujeitos são identificados impulsiona alguma caracterização do sujeito-objeto para a prossecução do processo e a identificação e utilização de instrumentos mais pertinentes para atingir a finalidade do trabalho educativo em saúde.

Nota-se que os relatos, não somente foram publicados em sua maioria por universidades públicas, mas também em sua maioria foram realizados por e em instituições públicas e que poucos trabalhos utilizaram espaços privados. Ou seja, é o setor público de saúde que parece caminhar rumo ao aperfeiçoamento do olhar sobre o objeto.

A maioria dos trabalhos educativos relatados demandou uma avaliação de resultado em médio e longo prazos já que se realizaram de dois a quatro ou sete encontros e poucos são os trabalhos que se desenvolvem em um único encontro. Esse 
resultado positivo, perante a noção de processo acima discutida, leva a crer que a demanda por esse tipo de avaliação tenha sofrido influência dos teóricos e das teorias do campo da educação. Todavia quando se relaciona a extensão do processo com a maneira como se faz a finalização do processo percebe-se que há uma quebra que dificulta saber até que ponto a transformação do objeto foi alcançada já que não há parâmetros temporais para avaliar a transformação do objeto.

A presença do "saber fazer" - concepção de saúde e de educação - que objetualiza a teoria que permite o recorte do objeto aliado aos "saberes operantes/instrumentais" - por exemplo, a educação em saúde - que transformam o objeto em produto aparece em poucos trabalhos. Como transformar o objeto do processo de trabalho educativo em saúde se o recorte não foi completamente traduzido em objetivação da subjetividade pretendida?

Decerto, alguns relatos analisados nesta pesquisa estão ancorados de sobremaneira no uso indiscriminado dos "saberes instrumentais" sem a concepção de saúde e de educação para nortear o esquadrinhamento do objeto a ser transformado com a prática educativa. Esquecendo-se

da teoria, à reificação dos conceitos, à substituição do humano, social e histórico pelo natural pseudoconcreto [ocorre a desvinculação com a práxis e] as conexões com o objeto real ao qual teve um dia querido buscar a máxima adequação: basta que a teoria tenha renunciado à reflexão (Mendes Gonçalves, 1990:355).

Uma vez que o produto não-material esperado dependerá da incorporação de conhecimentos e valores (formação que acompanha o processo educativo) durante toda a vida do sujeito, e que, portanto a transformação ou parte da transformação somente ocorrerá a médio e longo prazo, é interessante observar que as experiências relatadas nem sempre tentaram apreende-las ou sequer se preocuparam com isso. Os processos educativos em saúde tendem a ter somente objetivos instrucionais imediatos e não visam as transformações efetivas (que acontecem durante toda a vida do sujeito educando).

A reflexão da área de ensino universitário faz um paralelo adequado para compreender a preocupação dos agentes institucionais com o saber que é consumido no ato do processo educativo. É útil também para perceber que os agentes 
professores estão trazendo para o espaço do trabalho educativo com a população os métodos de avaliação do ensino universitário:

os resultados mais importantes do ensino se fazem sentir quando o estudante é levado a utilizar aquilo que aprendeu (métodos e técnicas tanto quanto conhecimentos). Essa utilização se estende ao longo de toda a sua vida, embora atualmente o professor em geral ignore completamente o destino da maior parte dos seus alunos. A experiência do ensino revela aos professores unicamente os efeitos a curto prazo (bom comportamento, classe viva, exito nos exames), o que explica o entusiasmo de muitos deles por tudo aquilo que possa atrair a atenção passiva dos estudantes (técnicas audiovisuais, manuais ilustrados, filmes, experiências de demonstrações espetaculares), sem com isso necessariamente exercitar os alunos a refletir ativamente e a tomar consciência de suas próprias responsabilidades educativas (Kourganoff, 1990: 88).

Nesse sentido, poucos trabalhos apresentaram a avaliação dos sujeitos e dos agentes da atividade educativa e alguns ainda não apresentaram a avaliação. Chama a atenção que em outros relatos os avaliados no processo educativo foram os agentes enquanto que os sujeitos não foram avaliados.

Paro (2002) ao analisar os elementos constituintes do trabalho pedagógico afirma que o consumo do produto educativo não se dá apenas imediatamente, como se supõe por muitas vezes o momento pedagógico proporcionado aos agentes-alunos de graduação e de pós-graduação em enfermagem e os sujeitos-população nos relatos analisados nesta pesquisa, mas se prolonga para além do ato de produção, por toda a vida do indivíduo. O saber incorporado ao indivíduo que permanece para além do processo pedagógico proporciona a formação de sua força de trabalho.

Uma vez que, a avaliação capta a transformação do objeto de trabalho ao final do processo de trabalho educativo, isto é, a finalidade subjetivada pelos agentes para o aprimoramento dos perfis de reprodução social dos sujeitos e objetivada concretamente na apreensão de temas que transformarão positivamente o cotidiano 
dos sujeitos é primordial a finalização do trabalho educativo com algum tipo de avaliação.

Sintetizando-se a partir do referencial teórico assumido por esta pesquisa a seguinte proposição:

Figura XIV - Elementos constituintes da finalidade do processo de trabalho educativo em saúde

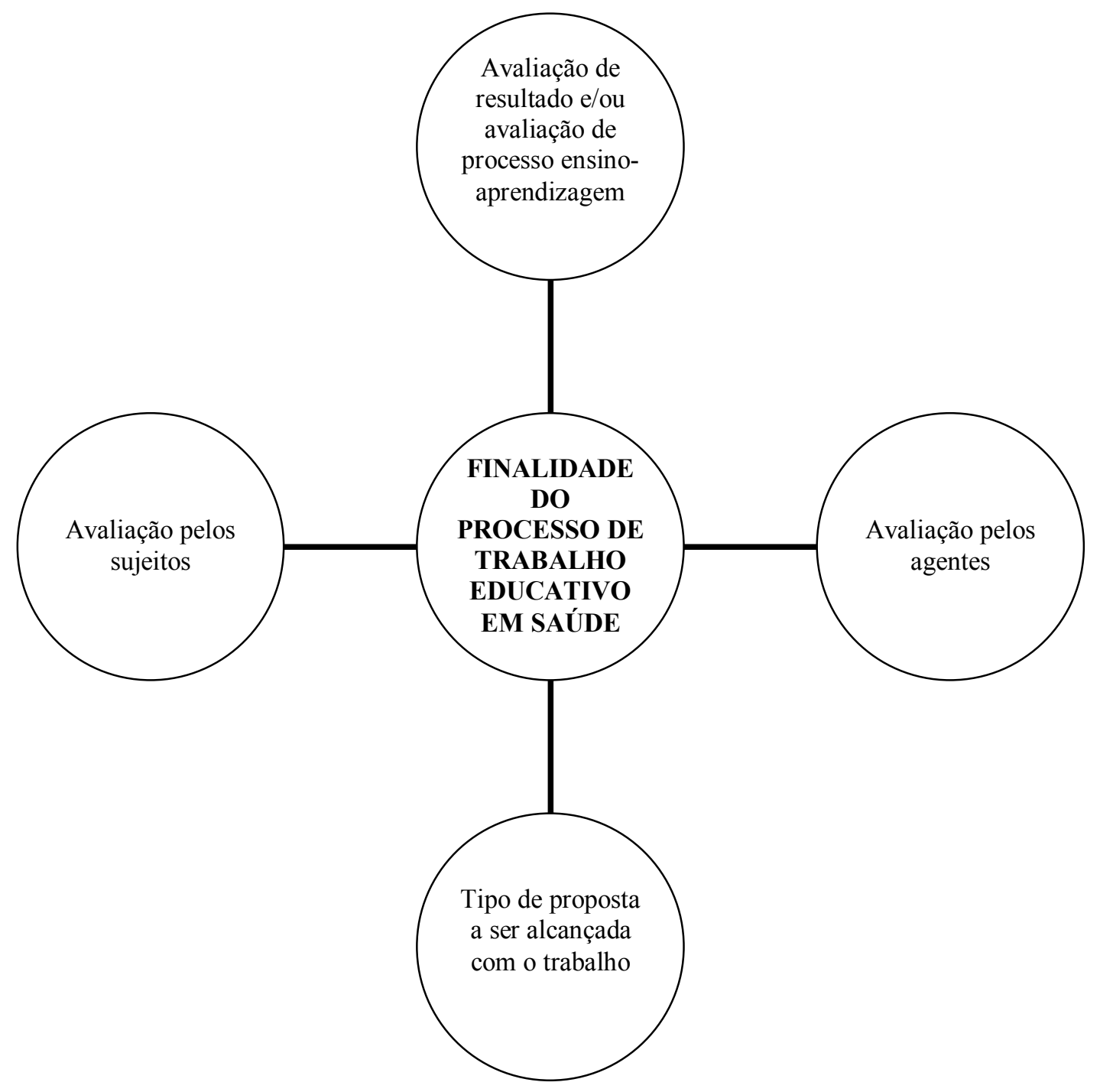


A avaliação de resultados, dessa maneira, fornece indicadores observáveis quantitativamente por meio de mudanças a médio ou longo prazos realizadas em direção às metas pretendidas e ao contexto geo-social dos sujeitos. Por sua vez, a avaliação do processo é de natureza qualitativa, já que a ênfase é colocada na descrição do tipo de encontros que ocorrem dentro (...) do processo, mais do que em resultados que podem ser quantificados (Aggleton, 1995:197).

Poucos relatos analisados nesta pesquisa apresentaram avaliações de resultado e a presença de muitas avaliações de processo indicam que a avaliação tende a ser "bancária" e que o saber não foi incorporado no sujeito porque o recorte do objeto não estava recortado com essa intenção, enquanto que outros trabalhos nem a avaliação mencionaram.

A avaliação para Caro (1982) tem dupla dimensão: uma que está relacionada com a informação e outra que está vinculada ao julgamento. Por isso, a avaliação fornece indícios para o alcance dos objetivos e o julgamento acerca do quanto os resultados desejados foram alcançados. Além disso, também permite concluir a validade do esforço empreendido no processo de trabalho educativo. Nesse sentido, a informação é extremamente importante para o processo avaliativo, uma vez que o desempenho por meio de indicadores verificáveis será comparado aos objetivos pretendidos.

Para Demo (1988:93), o que acontece muitas vezes, ao final da atividade educativa empreendida junto à população é o superdimensionamento

da importância do contexto político, em detrimento de melhorias concretas de vida das pessoas e grupos. A educação não cura a pobreza econômica. É puro pedagogismo pretender isto. Mas apresenta estratégias de superação da pobreza política, entendida como repressão da cidadania (...). [Além de ressaltar] a ligação com processos participativos, já que o cerne da educação é participação. Entendida como processo formativo, não apenas informativo, (...) pode elaborar condições favoráveis ao exercício da cidadania organizada, sendo ela mesma um dos canais de participação. 
$\mathrm{Na}$ medida em que os trabalhos educativos relatados pelos agentes que publicaram a atividade não mencionaram o processo avaliativo depreende-se que foi extirpado o momento de avaliar o quanto o trabalho foi competente para a transformação do objeto que desencadeou todo o processo educativo. A finalização do processo pode ter sido perdida pelo caminho.

E assim, se reproduz a idéia de que conscientizar algo para alguém é suficiente para transformar a realidade, deixando de lado a preocupação com processos auto-sustentados, em troca de mobilizações por vezes numerosas, mas restritas à efemeridade (...) de movimentos superficiais (Demo, 1988:95). 


\section{CONSIDERAÇÕES FINAIS}

O crescimento gradual dos relatos de experiência educativa da enfermagem na rede básica de serviços de saúde em saúde denota que a área vem contribuindo substancialmente para a consolidação da prática de educação em saúde no SUS.

A produção analisada nesta pesquisa foi assinada especialmente por docentes, do eixo sul-sudeste, com o local da atividade educativa fragilmente identificado e desenvolvidos a partir um roteiro teórico-metodológico-operacional assistemático que dificulta a compreensão do contexto e dos elementos das práticas educativas.

Nesse sentido, é imprescindível empreender esforços para o aprimoramento do processo de elaboração dos relatos identificando o contexto e os elementos teórico-metodológico-operacionais que fundamentam as práticas educativas em saúde.

Os resultados apontam que a dificuldade no esquadrinhamento do objeto do processo de trabalho educativo paralisa a prossecução dos demais elementos do processo de trabalho. Isso se justifica pelo pouco referencial teórico disponível para capturar o objeto do processo educativo em saúde.

Entre os relatos analisados a responsabilidade pelo "saber fazer" ficou a cargo do docente e dos alunos de pós-graduação e na maioria das vezes o "saber operante" por conta do aluno de graduação, pós-graduação ou dos trabalhadores da rede básica de serviços de saúde. Isso acompanhou a divisão pormenorizada do trabalho empreendida na prática social da enfermagem que dividiu tecnicamente o trabalho educativo em saúde, separando a concepção da execução.

Como a participação dos docentes nessas publicações é marcante torna-se imprescindível sua insubordinação à divisão pormenorizada do seu próprio trabalho a fim de promover a articulação entre o trabalho morto - que já passou por trabalho humano e o trabalho vivo - criador de valor nas práticas educativas em saúde que realiza com a população e com os alunos e trabalhadores de rede básica de serviços de saúde.

Observou-se que tanto os agentes-alunos de graduação e agentestrabalhadores vinculados a rede básica de serviços de saúde como os sujeitos para os quais a prática educativa se destina são subordinados pela parcial subsunção real empreendida nos trabalhos educativos em saúde, ou seja, participam pouco do planejamento das atividades educativas que é teorizado pelos docentes e alunos de 
pós-graduação em enfermagem ficando a seu cargo a parcela operacional do trabalho. Dessa forma, não apreendem a finalidade ou a necessidade de saúde geradora desse processo educativo.

O percurso metodológico empreendido nesta pesquisa não conseguiu capturar o conteúdo da finalidade do processo educativo, mas apenas a preocupação dos autores dos relatos em atingir alguma transformação. É possível que - e isso merece ser objeto de futuras investigações - a finalidade dos trabalhos educativos não seja algo claro para os autores.

Muitas vezes, os agentes do processo educativo se reportaram às concepções e aos instrumentos do campo da educação, mas não os articularam à concepção de saúde norteadora de sua prática social, para alicerçar o trabalho educativo em saúde.

Os recursos pedagógicos utilizados nos relatos potencializam a transformação dos temas que demandaram o processo educativo pelos sujeitos, uma vez que são métodos que estimulam a problematização e a participação dos sujeitos das práticas educativas.

No entanto, os saberes operantes que conformam a concepção de educação em saúde estão na dependência do que os múltiplos agentes do processo educativo reconhecem como objeto das práticas sociais em saúde que está em construção com o SUS.

Para que o processo de trabalho educativo em saúde seja de fato transformador da realidade de saúde nos moldes da saúde coletiva instrumentalização das classes/grupos sociais para a transformação dos perfis epidemiológicos - é necessário mais que a clareza no uso de recursos pedagógicos. É preciso que a enfermagem como uma das distintas práticas sociais em saúde componente do processo de produção de serviços de saúde - domine a concepção de saúde e de educação que objetualiza o recorte do objeto do processo de trabalho educativo e a concepção de educação em saúde que aprimora o saber instrumental para a transformação desse mesmo objeto. 


\section{REFERÊNCIAS}

Aggleton P. Monitoramento e avaliação de educação em saúde e promoção da saúde voltadas para o HIV/Aids. In: Czeresnia D, Santos EM, Barbosa RHS, Monteiro S. (org.). São Paulo: Rio de Janeiro: Abrasco; Hucitec; 1995.

Aguiar ZN. A qualificação dos atendentes de enfermagem: transformações no trabalho e na vida. [dissertação] São Paulo (SP): Escola de Enfermagem da USP; 2001.

Almeida MCP et al. Contribuição ao estudo da prática de enfermagem. Ribeirão Preto; 1981. [Documento da Escola de Enfermagem de Ribeirão Preto da Universidade de São Paulo].

Almeida MCP, Mishima SM, Peduzzi M. A pesquisa em enfermagem fundamentada no processo de trabalho: em busca da compreensão e qualificação da prática de enfermagem. Santa Catarina; 1999. [Revisão do artigo inédito apresentado na Mesa Redonda sobre Pesquisa em enfermagem no $51^{\circ}$ Congresso Brasileiro de Enfermagem e $10^{\circ}$ Congreso Panamericano de Enfermería].

Almeida MCP, Rocha SMM. Considerações sobre a enfermagem enquanto trabalho. In: Almeida MCP e Rocha SMM (org.) O trabalho de enfermagem. São Paulo: Cortez; 1997.

Althusser L. Sobre a reprodução. Petrópolis: Vozes; 1999.

Alves DB. É o trabalho na enfermagem um princípio educativo? Rev Bras Enf 1993; 46 (2): 149-155.

Antunes R. Os sentidos do trabalho: ensaio sobre a afirmação e a negação do trabalho. São Paulo: Boitempo; 2000. 
Augusto M. A importância da pesquisa em enfermagem. Acta Paul Enfermagem 1990 setembro; 3 (3):103-5.

Bernardo J. Dialéctica da prática e da ideologia. São Paulo: Cortez; Portugal: Edições Afrontamento; 1991.

Bordieu P. Contrafogos: táticas para enfrentar a invasão neoliberal. Rio de Janeiro: Jorge Zahar; 1998.

Breilh J, Granda E. Investigação da saúde e sociedade: guia pedagógico sobre um novo enfoque do método epidemiológico. São Paulo: Instituto de Saúde/Abrasco; 1986.

Breilh J. Nuevos conceptos y técnicas de investigacion: guia pedagógica para um taller de metodologia (epidemiologia del trabajo). Ecuador: Centro de estúdios y asesoría em salud; 1995.

Calipo S. Saúde, Estado e ética - NOB/96 e lei das organizações sociais: a privatização da instituição pública na saúde? [dissertação] São Paulo (SP): Escola de Enfermagem da USP; 2002.

Campos CMS. Necessidades de saúde pela voz da sociedade civil (os moradores) e do Estado (os trabalhadores de saúde). [tese] São Paulo (SP): Escola de Enfermagem da USP; 2004.

Caro FG. Pesquisa avaliativa: uma visão parorâmica. In: Goldberg MAA, Souza CP (org.) Avaliação de programas educacionais: vicissitudes, controvérsias, desafios. São Paulo: EPU; 1982. p. 10-14.

Carvalho SR. As contradições da promoção à saúde em relação à produção de sujeitos e a mudança social. Ciência \& Saúde Coletiva 2004a; 669-678.

Carvalho SR. Os múltiplos sentidos da categoria "empowerment" no projeto de promoção à saúde. Cad Saúde Pública 2004b; 20 (4). 
Castellanos BEP. Estrutura conceitual da enfermagem brasileira. Rev. Esc. Enf. USP 1988; 22 (esp.): 31-42.

Cezar Vaz MR, Sena J, Martins SR, Rubira LT, Santos LR, Cabreira GO et al. Educação e produção de saúde: um estudo da enfermagem de saúde coletiva no extremo sul do Brasil. Texto e Contexto Enferm 2003; 12(1): 59-67.

Chauí M. A universidade operacional. Folha de São Paulo [Caderno Mais, 9 de maio] São Paulo; 1999.

Chauí M. Convite à filosofia. 9a ed. São Paulo: Ática; 1997.

Chiesa AM, Veríssimo MDLOR. A educação em saúde na prática do PSF. In: Brasil. Instituto para o Desenvolvimento da Saúde. Universidade de São Paulo. Ministério da Saúde. Manual de Enfermagem. 2001.

Chizzotti A. Pesquisa em ciências humanas e sociais. São Paulo: Cortez; 2001.

Cianciarullo TL, Salzano SDT. A enfermagem e a pesquisa no Brasil. Rev Esc Enf USP 1991 agosto; 25(2):195-215.

Collet N, Schneider JF, Corrêa AK. A pesquisa em enfermagem: avanços e desafios. Rev Bras Enferm 2000 janeiro; 53(1):75-80.

Demo P. Avaliação qualitativa. São Paulo: Cortez; Editores Associados; 1988.

Egry EY. Saúde coletiva: construindo um novo método em enfermagem. São Paulo: Cone; 1996.

Fiorin JL. Linguagem e ideologia. São Paulo: Ática; 1990.

Freire P. Pedagogia do oprimido. $32^{\circ}$ ed. Rio de Janeiro: Paz e Terra; 2002. 
García JC. O nascimento da medicina social. In: Nunes ED (org.) Pensamento social em saúde na América Latina. São Paulo: Cortez; 1983.

Germano RM. Educação e ideologia da enfermagem no Brasil. São Paulo: Cortez; 1983.

Gonzaga FRSR O processo educativo em saúde como prática assistencial: relato de experiência. Texto \& Contexto-Enfermagem 1992b janeiro; 1(1):116-136.

Gonzaga FRSR Para além do cotidiano: reflexões acerca do processo de trabalho de educação em saúde. [dissertação]. Florianópolis (SC): Centro de Ciências da Saúde/UFSC; 1992a.

Konder L. A dialética e o marxismo. Rio de Janeiro: 2002. Disponível em: www.uff.br/trabalhonecessario/Konder\%201.htm (03 dez. 2004)

Kourganoff W. A face oculta da universidade. São Paulo: Editora da UNESP; 1990.

Kuenzer AZK. Pedagogia da fábrica: as relações de produção e a educação do trabalhador. São Paulo: Cortez; Autores Associados; 1986.

Laurell AC, Noriega M. Processo de produção e saúde: trabalho e desgaste operário. São Paulo: Hucitet; 1989.

Laurell ACA. Saúde doença como processo social. In: Nunes ED. (org.) Medicina social: aspectos históricos e teóricos. São Paulo: Global; 1983. p.133-158.

Lessa S. A centralidade ontológica do trabalho em Lukács. Serviço social e sociedade 1996; (52): 7-23.

Lessa S. Lukács e a ontologia: uma introdução. Revista Outubro 2001; (5): 83-100. 
Lobo E. A pesquisa e a metodologia da educação para a saúde. In: Pino IR. (org.) Cadernos do Cedes - Centro de estudos Educação e Sociedade. São Paulo: Autores associados, Cortez. 1987. (4) p.55-64.

Marx K. Contribuição à crítica da economia política. São Paulo: Martins Fontes; 1977.

Marx K. O capital: crítica da economia política. Livro 1: O processo de produção capitalista. Rio de Janeiro: Civilização Brasileira; 1968. 1v.

Marx K. O capital: crítica da economia política. Livro I: capítulo VI (inédito). São Paulo: Ciências Humanas; 1978.

Matumoto S, Mishima SM, Pinto IC. Saúde Coletiva: um desafio para a enfermagem. Cad Saúde Pública 2001; 17 (1): 233-241.

Melo CMM. A divisão social do trabalho e enfermagem. São Paulo: Cortez; 1986.

Mendes Gonçalves RB. A contribuição à discussão sobre as relações entre teoria, objeto e método em epidemiologia. [Anais do $1^{\mathrm{o}}$ Congresso Brasileiro de Epidemiologia] Campinas: São Paulo; 1990.

Mendes Gonçalves RB. Medicina e história: raízes sociais do trabalho médico. [dissertação] São Paulo (São Paulo): Faculdade de Medicina da USP; 1979.

Mendes Gonçalves RB. Práticas de saúde: processos de trabalho e necessidades. São Paulo: CEFOR; 1992.

Mendes Gonçalves RB. Tecnologia e organização social das práticas de saúde: características tecnológicas do processo de trabalho na rede estadual de centros de saúde de São Paulo. São Paulo: Hucitec-Abrasco; 1994. p. 55-104.

Merhy E. Saúde e movimento popular: o relato de uma experiência. In: Pino IR. (org.) Cadernos do Cedes - Centro de estudos Educação e Sociedade. São Paulo: Autores associados, Cortez; 1987. (4) p.45-53. 
Misoczky MC. A agenda para reformas do banco mundial e a política de saúde: algumas notas para reflexão. Saúde em debate 1995; (47): 4-7.

Nakamae DD. Bases para o encaminhamento do ensino de enfermagem. São Paulo: Cortez, 1987.

Paim JS, Almeida Filho N. Saúde coletiva: uma "nova saúde pública" ou campo aberto a novos paradigmas? Rev Saúde Pública 1998; 32 (4): 299-316.

Paro VH. Administração escolar: introdução crítica. $11^{\circ}$ ed. São Paulo: Cortez; 2002a.

Paro VH. Escritos sobre educação. $1^{0}$ ed. São Paulo: Xamã; 2001.

Paro VH. Gestão democrática da escola pública. $3^{\circ}$.ed. São Paulo: Ática; 2002 b.

Pêcheux M. O. discurso: estrutura ou acontecimento. Campinas:Pontes; 1990.

Peduzzi M. Laços, compromissos e contradições existentes nas relações de trabalho da enfermagem. São Paulo: 2001; [Revisão do artigo inédito apresentado na Mesa Redonda: A situação atual, as transformações e as oportunidades no mundo do trabalho da Enfermagem ao $53^{\circ}$ Congresso Brasileiro de Enfermagem]

Pires D. Reestruturação produtiva e trabalho em saúde no Brasil. São Paulo: Confederação Nacional dos Trabalhadores em Seguridade Social - CUT; Annablume; 1998.

Queiroz VM, Salum MJL. Ensaios para uma nova abordagem em enfermagem em saúde coletiva: resistindo às armadilhas da globalização subordinada e construindo a globalização da solidariedade social. La Havana: Cuba; 2000. [Revisão do artigo inédito apresentado no $8^{\circ}$ Congresso Latinoamericano de Medicina Social e $11^{\circ}$ Congresso da Associação Internacional de Políticas de Saúde]. 
Queiroz VM, Salum MJL. Reconstruindo a intervenção de enfermagem em saúde coletiva. São Paulo; 1996. [Revisão do artigo inédito apresentado em Sessão de Comunicação Coordenada ao $48^{\circ}$ Congresso Brasileiro de Enfermagem].

Rubin II. A teoria marxista do valor. São Paulo: Polis; 1987.

Sabroza P. Concepções sobre saúde e doença. Disponível em: www.ead_ensp.fiocruz.br/cursos/autogestao/ags/apresentação/autogestão/contexto/te ma1.html. Acessado em: 01 jun. 2005.

Salum MJL, Bertolozzi MR, Oliveira MAC. O coletivo como objeto da enfermagem: continuidades e descontinuidades da história. In: Organização Panamericana de Saúde. Enfermagem nas Américas. Washington: OPS; 1999. p. 101-17.

Salum MJL, Queiroz VM, Soares CB. Pesquisa social em saúde: lições gerais de metodologia - a elaboração do plano de pesquisa como momento particular da trajetória teórico-metodológica. [Trabalho apresentado ao $2^{\circ}$ Congresso Brasileiro de Ciências Sociais em Saúde; 1999; São Paulo (SP).

Saviani D. Escola e democracia: teorias da educação, curvatura da vara, onze teses sobre a educação política. Campinas (São Paulo): Autores associados; 2003.

Saviani D. Pedagogia histórico-crítica: primeiras aproximações. Campinas (São Paulo): Autores associados; 2005.

Schraiber LB e Mendes Gonçalves RB. Necessidades de saúde e atenção primária. In: Schraiber LB Nemes MIB e Mendes Gonçalves RB. (org.) Saúde do adulto: programas e ações na unidade básica. São Paulo: Hucitet-Abrasco; 2000.

Silva GB et al. Introdução à análise das transformações da prática de enfermagem no Brasil no período de 1920-1978. Rev Medicina 1984; 1/2 (17): 35-47.

Silva GB. Enfermagem profissional: análise crítica. São Paulo: Cortez; 1986. 
Silva MEK, Gonzaga FRSR, Verdi MM. Marco conceitual para a prática assistencial de enfermagem enquanto processo educativo em saúde. Rev Bras Enferm 1992; 45 (1): 54-59.

Soares CB, Salum MJL. A instrumentalização da inteligência popular. São Paulo; 1999. [Documento pedagógico do Departamento de Enfermagem em Saúde Coletiva da Escola de Enfermagem da Universidade de São Paulo]

Stotz EM, Araújo JWG. Promoção da saúde e cultura política: a reconstrução do consenso. Saúde e sociedade 2004; 13 (2): 5-19.

UIPES - União Internacional de Promoção da Saúde e Educação Para a Saúde. Formação de recursos humanos para a área da educação em saúde: diretrizes. Rio de Janeiro: SESI; 1998a.

UIPES - União Internacional de Promoção da Saúde e Educação Para a Saúde. Diagnóstico das ações de educação em saúde no Brasil. Rio de Janeiro: SESI; 1998b.

Vargas MN, Soares LTR. O trabalho educativo em saúde nas comunidades rurais: as experiências da enfermagem no Brasil e no Peru. Esc Anna Nery Rev Enferm 1997; $1(2): 54-71$.

Vasconcelos EM. Educação popular nos serviços de saúde. São Paulo: Hucitec; 1997.

Vázquez AS. Filosofia da práxis. Rio de Janeiro: Paz e Terra; 1986.

Victora CG, Facchini LA, Barros FC, Lombardi C. Pobreza e saúde: como medir nível sócio-econômico em estudos epidemiológicos de saúde infantil? [Anais do $1^{\mathrm{o}}$ Congresso Brasileiro de Epidemiologia] Campinas: São Paulo; 1990. 


\section{ANEXO I}

\section{MATERIAL EMPÍRICO}

Alves MDS, Varela ZMV. O jornal como o veículo no processo de mobilização e organização de grupos comunitários. Rev. Bras. Enferm. 1988; 41(2): 140-4.

Alvim NAT, Lourenço LHSC. Projeto UFRJ, como vai a sua saúde?. Rev. Alternativa Enferm. 1997; 1(4): 14-21.

Araújo EG, Nunes MMLG. Atos e autores - o lúdico na educação em saúde. Rev. Bras. Enferm. 1996; 49(3): 459-74.

Araújo MFM, Almeida MI, Silva RM. Aids/educação e prevenção: proposta metodológica para elaboração de jogos educativos. Rev. Bras. Enferm. 2000; 53(4): 607-613.

Brum ZP, Pereira MA. Educação em saúde enfocando higiene, sexualidade e drogadição junto aos meninos de rua na faixa etária de 11 a 14 anos. Rev. Bras. Enferm. 1996; 49(3): 333-42.

Coelho EBS, Pimentel CPB, Patrício ZM. Sem medo de mudar: desenvolvendo um método de ensino-aprendizagem participante. Texto Contexto Enferm. 1994; 3(2): 149-56.

Costa DDG, Lunardi VL. Enfermagem e um processo de educação sexual com adolescentes de uma escola pública. Texto Contexto Enferm. 2000; 9(2): 46-57.

Costa MBS, Lima CB, Silva MIT, Vilela MASD. Práticas de ensino em programas de saúde desenvolvida com alunos do ensino fundamental. Esc. Anna Nery Rev. Enferm. 1999; 3(3): 136-43. 
Cozzupoli CA, Barbieri M. A enfermeira obstétrica e sua atuação para a vida familiar como atividade da obstetrícia social. Acta Paul. Enferm. 1988; 1(4): 110-2.

Cunha ICKO. Gente cuidando de gente: a arte do cuidar pelas ondas do rádio. Rev. Bras. Enferm. 2000; 53(3): 431-434.

Chiesa AM, Westphal MF. A sistematização de oficinas educativas problematizadoras no contexto dos serviços públicos de saúde. Saúde Debate. 1995; $46: 19-22$.

Dreher ML, Ferreira SRS, Eidt OR. Prevenção da aids: experiência participativa com adolescentes de uma escola estadual de $1^{\text {o }}$ grau em Porto Alegre. Rev. Gaúcha Enferm. 1995; 16(1/2): 52-7.

Dyniewicz AM. Educando-nos em grupo por ações reflexivas em saúde: uma ênfase na prática assistencial da enfermeira. Cogitare Enferm. 1999; 4(1): 64-74.

Dytz JLG, Cristo RC. A ludoteca como espaço para uma nova abordagem de educação em saúde. Rev. Bras. Enferm. 1995; 48(2): 134-139.

Esperidião E, Oliveira MAE, Pontiere MSS. Sala de espera: uma ocasião de atenção primária em saúde mental: relato de experiência. Rev. Bras. Enferm. 1992; 45(2/3): $145-8$.

Farias FTPF, Padilha MICS. Educação em saúde: co-participação das educadoras infantis no processo saúde-doença no centro de desenvolvimento infantil. Texto Contexto Enferm. 2000; 9(2): 336-47.

Gambá MA, Brêtas JRS, Carvalho AMP, Massunaga VM, Sant'Anna ME. Atuação do enfermeiro na educação em saúde a pré-escolares da periferia do município de São Paulo - relato de uma experiência. Acta Paul. Enferm. 1990; 3(1): 11-6. 
Gonçalves AF, Castro APR, Souza LJEX, Franco MC. Desenvolvendo hábitos saudáveis de educação em saúde na adolescência. Texto Contexto Enferm. 1998; 7(3): 130-45.

Gonzaga FRSR. O processo educativo em saúde como prática assistencial: relato de experiência. Texto Contexto Enferm. 1992; 1(1): 116-36.

Heidemann ITSB. A necessidade de organização comunitária através de uma participação consciente com uma comunidade de baixa renda. Texto Contexto Enferm. 1993; 2(1): 100-10.

Hoga LAK. Educação para a saúde com grupo de adolescentes. O mundo da saúde. 1997; 21(2): 68-74.

Jesus MCP, Machado VAR, Mello FF, Fonseca SR. Educação sexual na escola: experiência de docentes e acadêmicas de enfermagem com adolescentes, pais e professores. Texto Contexto Enferm. 1999; 8(1): 357-71.

Klein EP. Extensão universitária: um programa de educação popular em saúde. Rev. Baiana de Saúde Públ. 2003; 27(1/2): 84-98.

Landerdahl MC. Mulher climatérica: uma abordagem necessária ao nível da atenção básica. Nursing 2002; 5(47): 20-25.

Martini JG, Gregis C, Jardim L. Gravidez na adolescência: da prática disciplinadora à pedagogia libertadora. Rev. Bras. Enferm. 1999; 52(4): 539-546.

Mello CMM, Vilasbôas AL. Capacitação de conselheiros de saúde - uma experiência na secretaria municipal de saúde de Salvador 1993-96. Rev. Baiana Enferm. 1999; 12(2): $42-54$.

Mendes IJM. Uma proposta holística de educação do adulto numa perspectiva positiva de saúde. Rev. Bras. Enferm. 1996; 49(1): 31-40. 
Miranda VLA, Carniel EF, Caraffa RC, Oliveira SP. Programa integrado de educação e saúde escolar (PIESE): relato de uma experiência. J. Pediatr. 1989; 65(7): 259-63.

Moraes LMP, Braga VAB. Trabalhando a orientação sexual com alunos do ensino fundamental: atuação da enfermagem. Rev. Rene. 2001; 2(2): 67-71.

Nitschke RG, Martins CR, Verdi M. O lúcido lúdico. Texto Contexto Enferm. 1998; 7(3): 118-129.

Noccioli MM, Ferriani MGC, Silva MAI, Cano MAT. O controle das doenças transmissíveis na escola: uma abordagem crítica e reflexiva. Rev. Bras. Saúde Esc. 1994; 3(1-4): 168-74.

Oliveira MAC. Educação em saúde: uma estratégia no processo ensinoaprendizagem - relato de uma experiência. Rev. Bras. Saúde Esc. 1994; 3(1/4): 1304.

Patrício ZM. Nem talco nem diamante: a riqueza de um processo de ensinoaprendizagem participante na área da sexualidade-adolescência. Texto Contexto Enf. 1994; 3(2): 93-109.

Pereira GA, Lima MADS. Relato de experiência com grupo na assistência de enfermagem a diabéticos. Rev. Gaúcha Enferm. 2002; 23(2): 142-57.

Rodrigues MGS, Kantorski LP, Gomes VLO. Um processo de educação em saúde desenvolvido com um grupo de mães de crianças com algum grau de desnutrição. Texto Contexto Enferm. 2000; 9(2): 169-77.

Sant'Anna SC, Ferriani MGC. O trabalho de grupo: reflexões do cotidiano, relato de uma experiência. Rev. Latino-Am. Enferm. 2000; 8(3): 97-101. 
Schneider JF, Collet N, Orso PJ, Pereira JO. Acompanhamento de enfermagem em saúde pública, assessoramento pedagógico e agrícola numa comunidade de assentados sem terra na zona rural: relato de experiência. Rev Latino-Am. Enferm. 1995; 3(1): 137-47.

Silva RP, Wosny AM, Bohes AE, Verdi M, Borestein M. Campanha da vacinação: espaço para se fazer educação em saúde. Rev. Ciênc. Saúde 1994; 13 (1/2): 60-9.

Sousa AI. Programa universidade solidária - 1998: relato de experiência no município Pedras de Fogo, Paraíba. Esc. Anna Nery Rev. Enferm. 1998; 2(1/2): 12738.

Sousa RA, Pagliuca LMF. Educação em saúde como fator de participação da enfermeira na construção da cidadania do surdo: reflexão crítica. Esc. Anna Nery Rev. Enferm. 2002; 6(3): 491-499.

Sousa RA, Pagliuca LMF. Saúde sexual e reprodutiva para surdos: apreciação de uma metodologia educativa. Acta Paul. Enferm. 2003; 16(1): 22-29.

Souza AC, Lopes MJM. Implantação de uma ouvidoria em saúde escolar: relato de experiência. Rev. Gaúch. Enferm. 2002; 23(2): 123-41.

Tupynambá LCTA, Borrasca R. Treinamento do agente de saúde em escola estadual de primeiro grau no município de Embu/SP. Acta Paul. Enf. 1990; 3(2): 55-8.

Tupynambá LCTA, Brêtas ACP, Leite ECC, Romero ER, Melo MMS. O atendimento de enfermagem em grupo no programa de saúde da criança. Acta Paul. Enf. 1988; 1(2): 38-41.

Vieira PM, Liz TG, Gesser VL, Boehs AE. O teatro como alternativa de se educar em saúde. Texto Contexto Enferm. 1999; 8(1): 372-83. 
Witt RR, Backes DL, Strim C, Rodrigues D. Enfermagem rural. Rev. Gaúcha Enferm. 2000; 21(1): 22-30. 


\section{ANEXO II}

\section{INSTRUMENTO DE COLETA DE DADOS}

$\mathrm{N}^{\mathrm{o}}$. do formulário:

\section{A - DESCRIÇÃO GERAL}

Área geo-social do estudo (região brasileira, estado, município, bairro, comunidade):

Revista:

Local de vínculo e participação dos autores nas publicações:

Caráter da instituição vinculada aos autores:

Ano de publicação:

B - DESCRIÇÃO ESPECÍFICA: O PROCESSO DE TRABALHO EDUCATIVO

\section{OBJETO DE TRABALHO}

Indicador de trabalhador/serviço envolvido:
a)planejamento -
b)execução -

Indicador tipo de trabalhador/universidade envolvido:

a)planejamento -

b)execução -

Indicador de necessidade geradora:

a)ensino de enfermagem ( ) b)assistência de enfermagem ( )

Indicador de presença das concepções constituintes do "saber fazer":

a)saúde e educação ( ) b)educação ( ) c)saúde ( ) d)sem informação ( )

Indicador de tema:

Indicador de participação no planejamento dos temas:

a) $\operatorname{sim}(. .$.$) b)não (...)$

Indicador de qualificação empírica do sujeito: 
Indicador de âmbito de atuação grupal:

\section{MEIOS / INSTRUMENTOS DE TRABALHO}

Indicador de identificação do espaço físico:

a)organizações/instituições privadas:

ONGS ( ) Creches conveniadas ( ) Associações e centros comunitários ( ) Instituições religiosas ( ) Outro

b)organizações/instituições governamentais:

Creches( ) Escolas( ) UBS( ) Universidades ( ) Outro

Indicador de freqüência dos encontros:

a)um encontro ( ) b)dois encontros ( )

c)três encontros ( ) d)quatro a sete encontros ( ) e)sem informação ( )

Indicador de presença da concepção constituinte do "saber operante":

a)educação em saúde ( ) b)sem informação ( )

Indicador de tipo de recurso didático:

\section{FINALIDADE DO TRABALHO}

Indicador de tipo de avaliação:

a)resultado ( ) b)processo ( ) c)sem informação ( )

Indicador de meta a ser alcançada:

a)comportamento saudável ( ) b)controle e prevenção de doenças ( ) c)discussão sobre os fatores causais das doenças ( ) d)melhoria das condições de vida e)melhoria das condições de trabalho ( )

Indicador de articulação entre as concepções constituintes do "saber fazer" e do "saber operante":

a)saúde, educação e educação em saúde $(\quad$ ) b)educação e educação em saúde ( ) c)saúde e educação em saúde ( ) d)sem articulação ( ) e)sem informação ( )

Indicador de identificação dos avaliados:

a)agentes ( ) b)sujeitos ( ) c)agentes e sujeitos ( ) d)não houve avaliação ( ) 


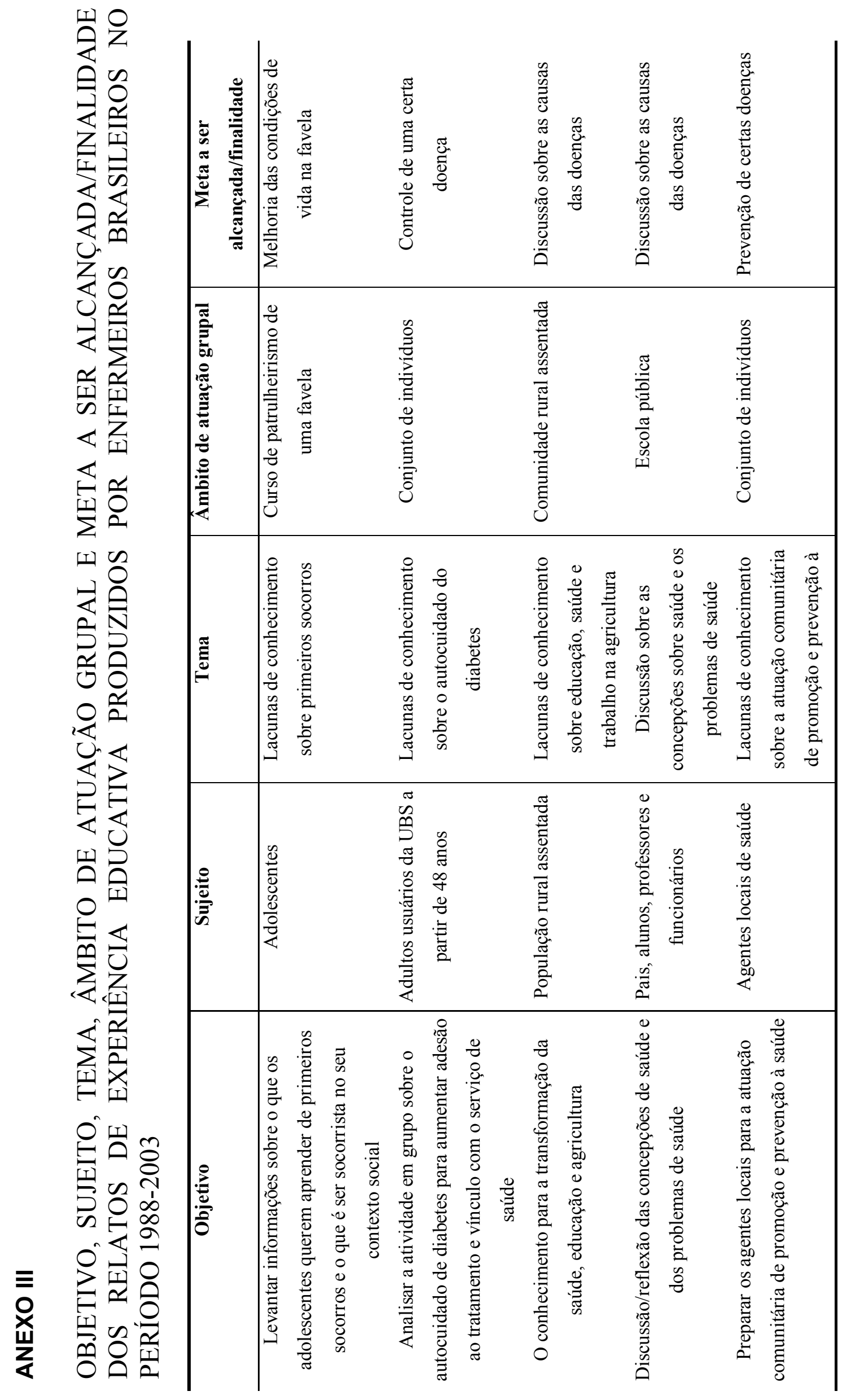




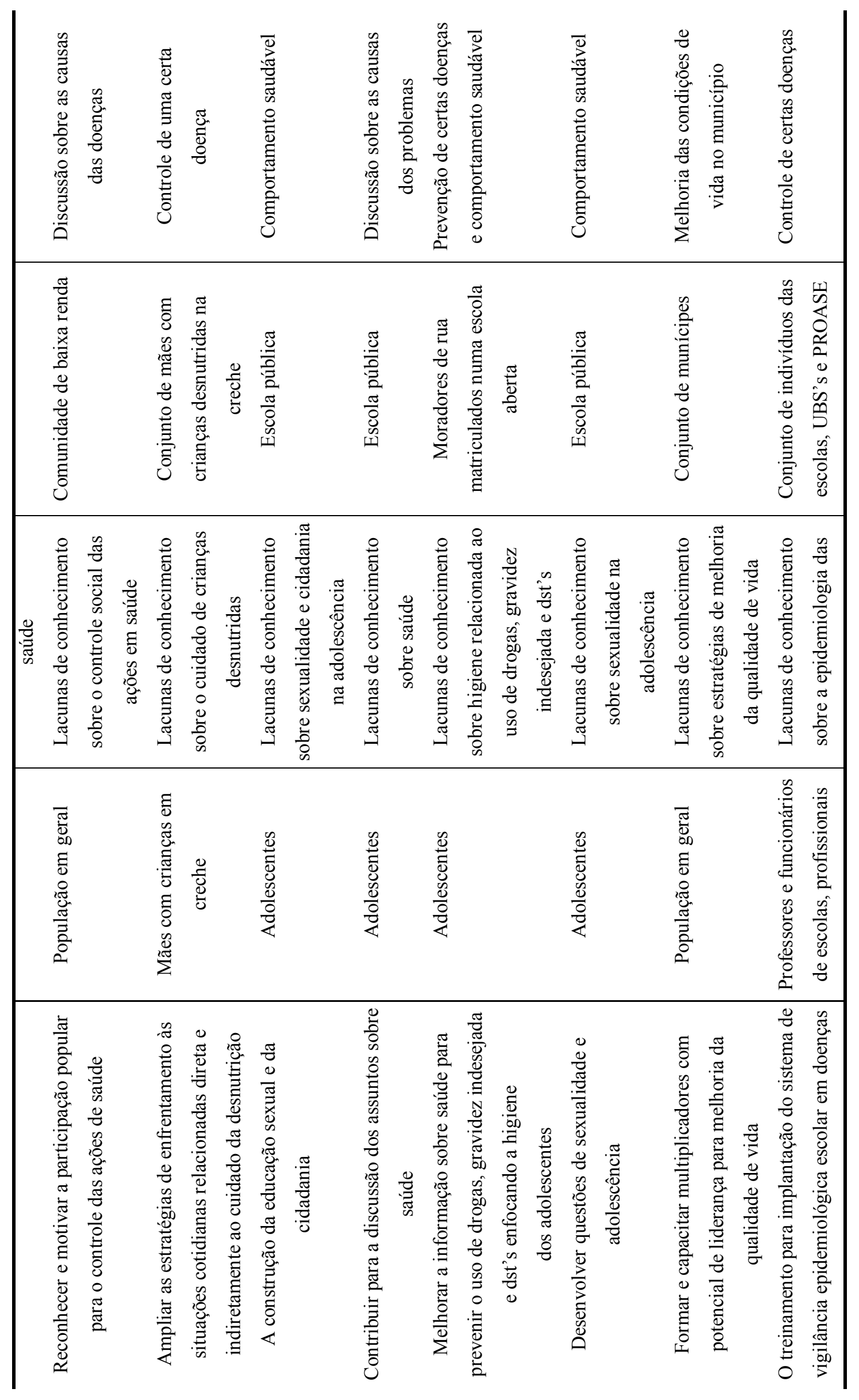




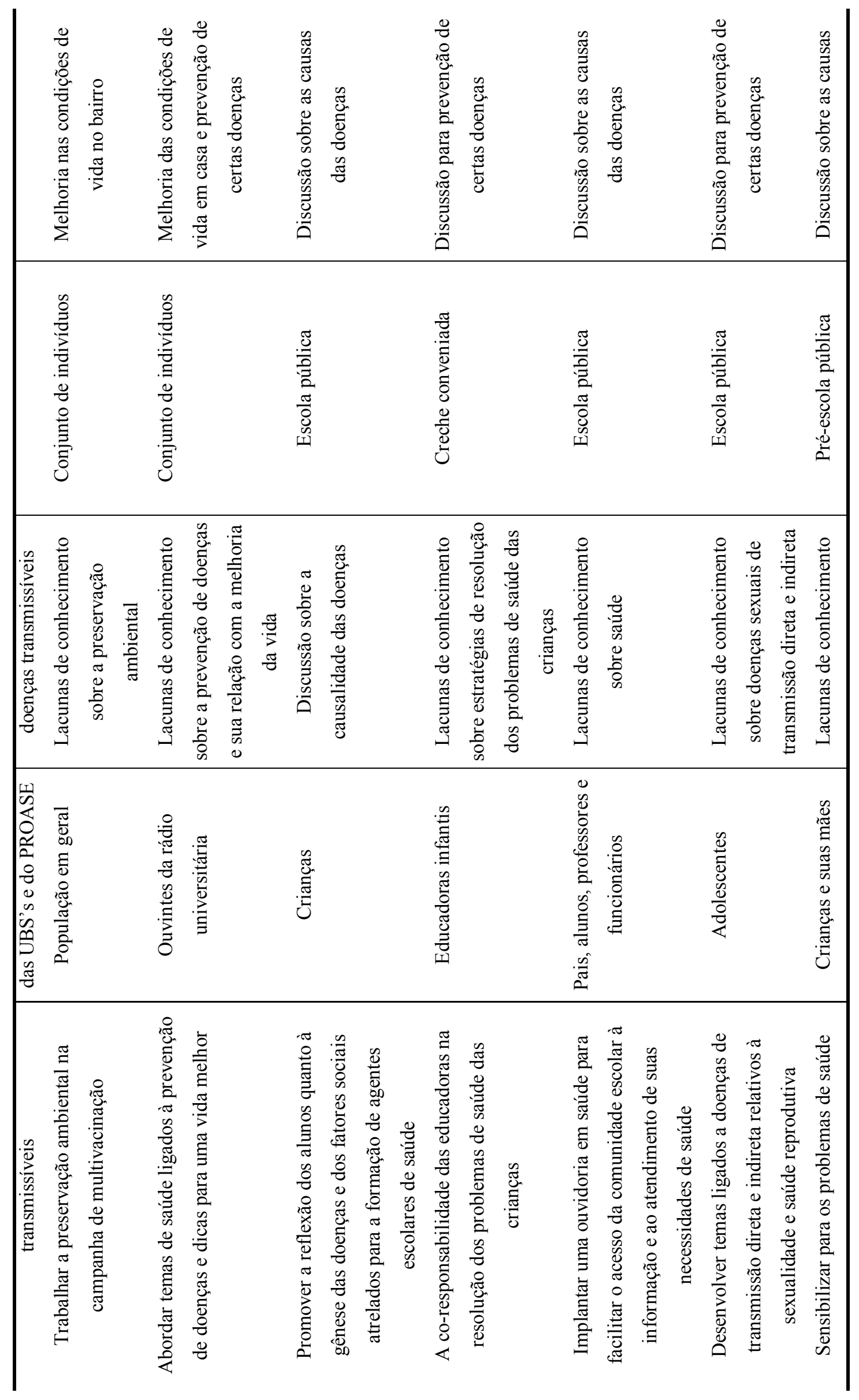




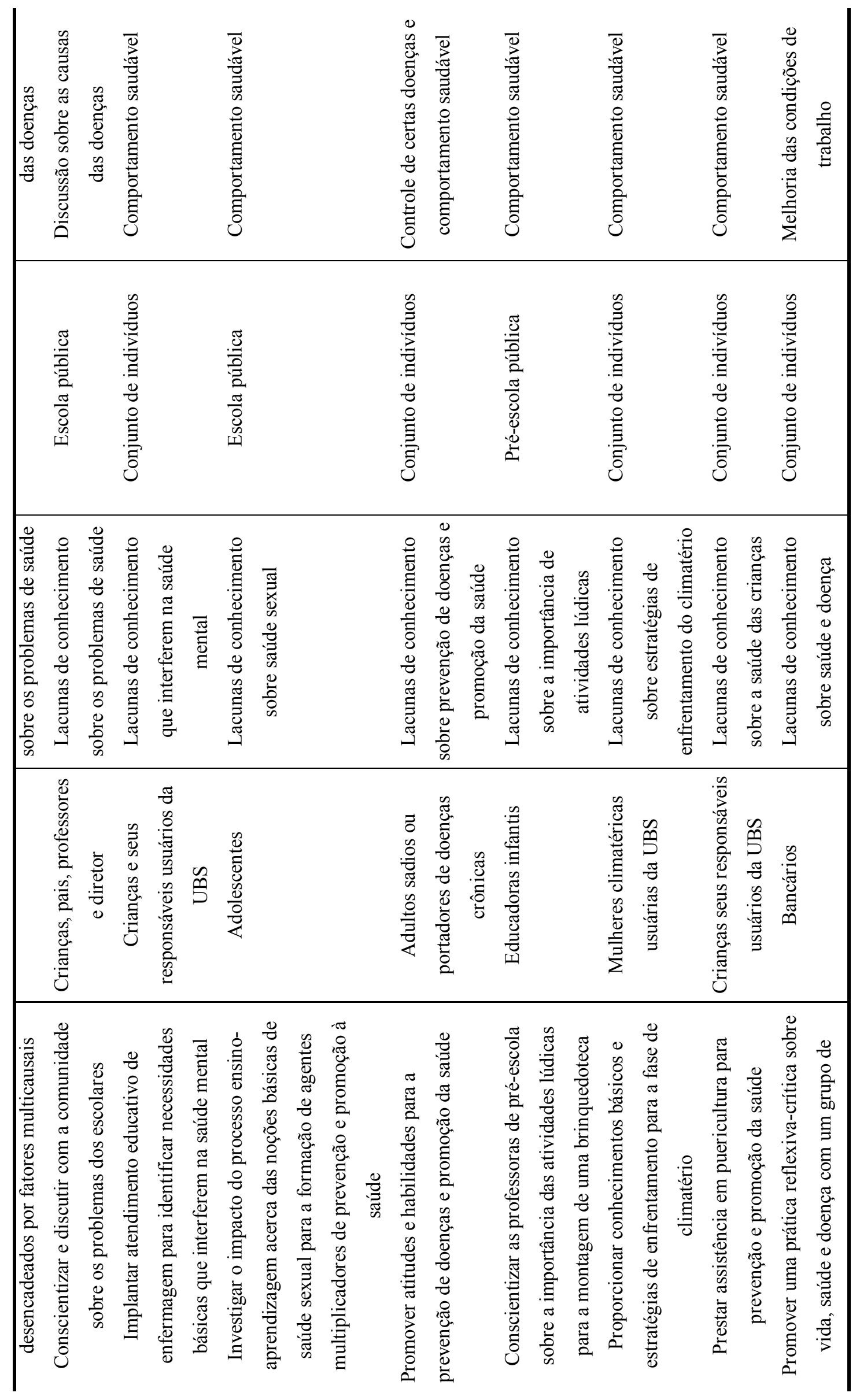




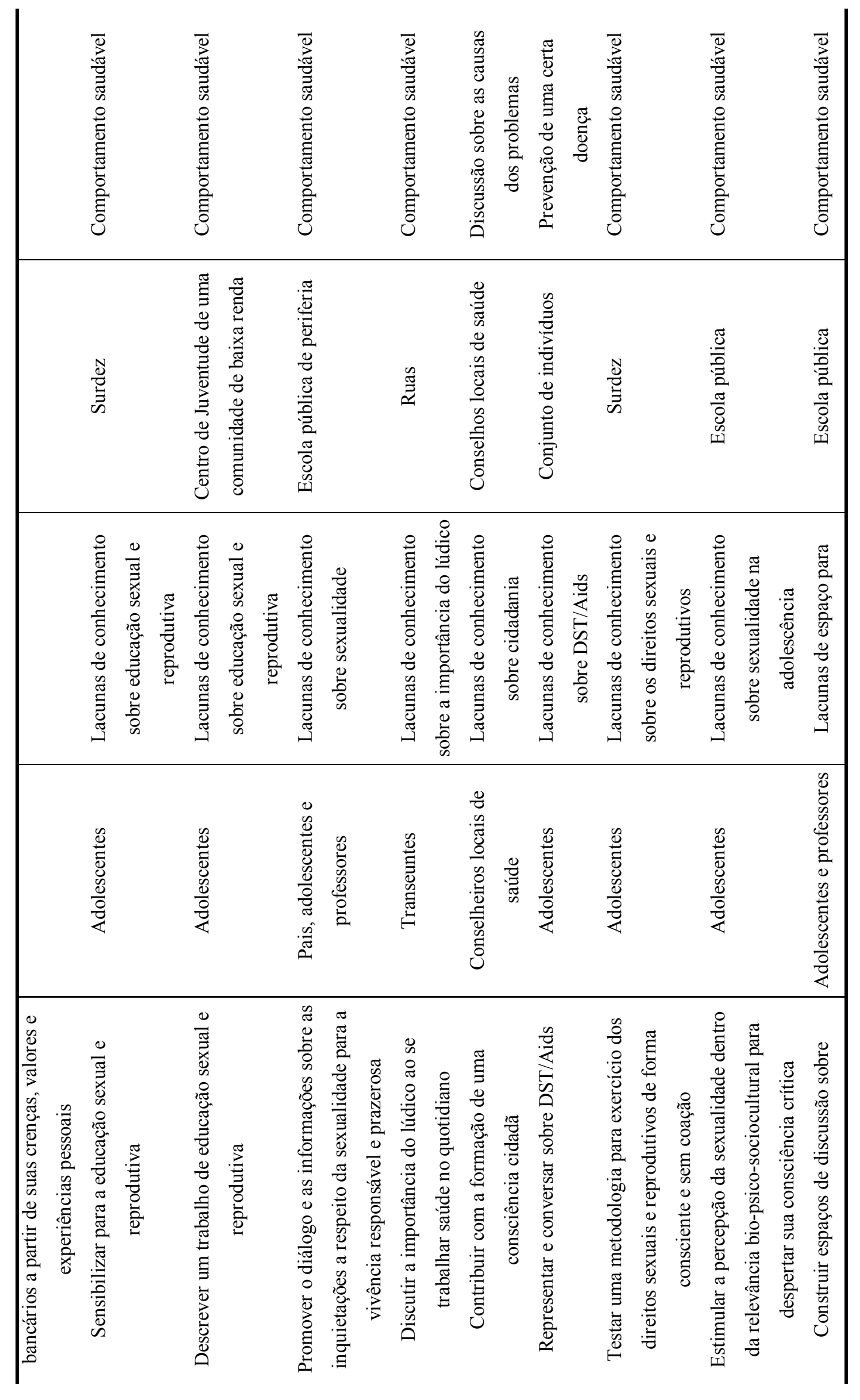




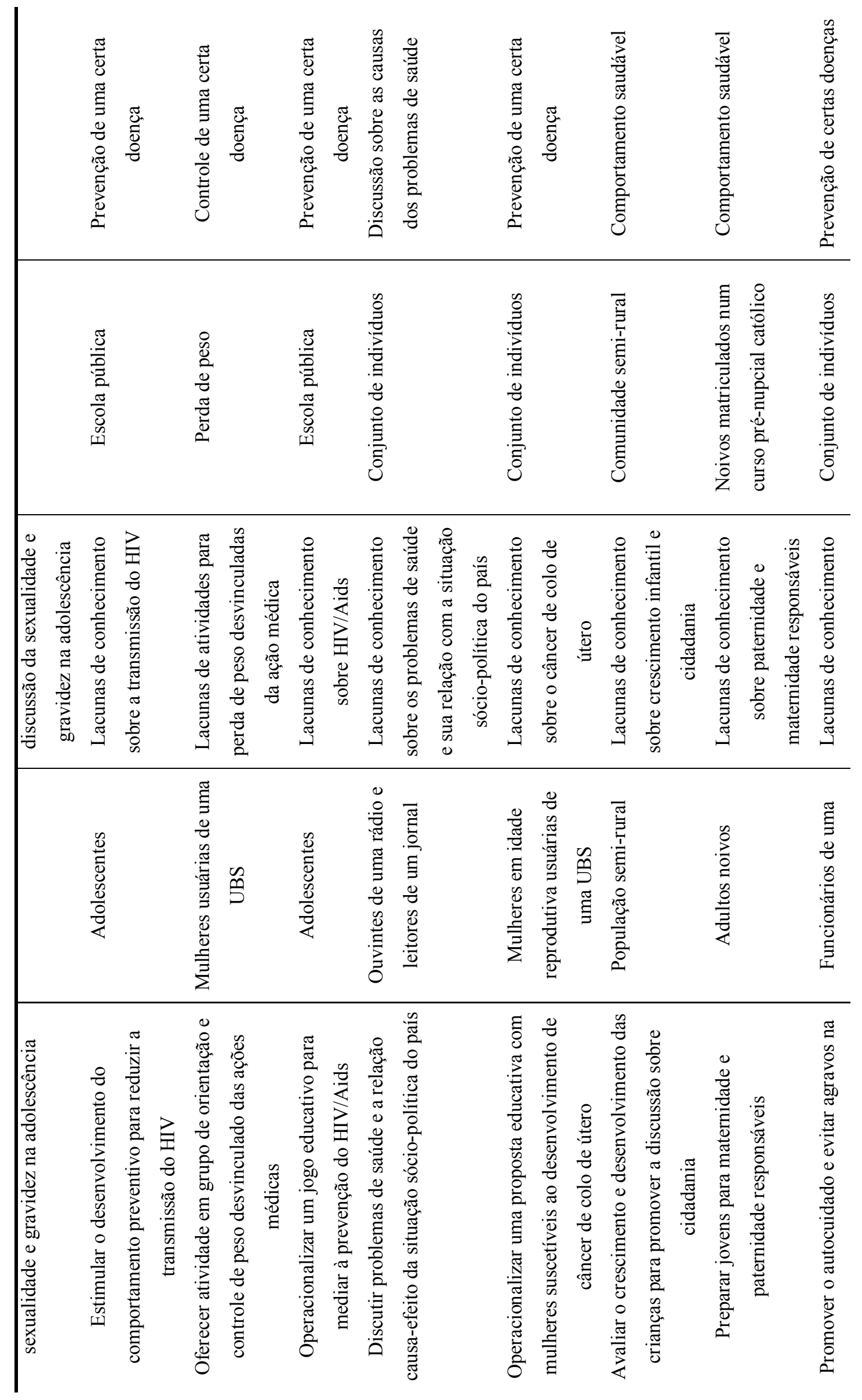




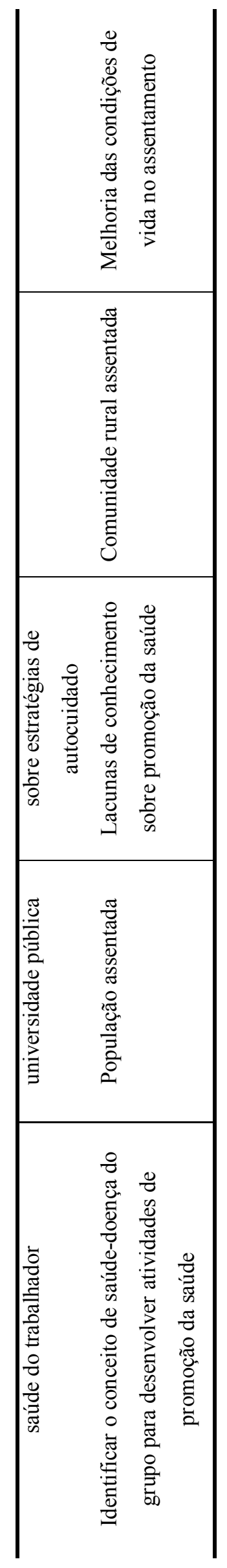




\section{ANEXO IV}

\section{META A SER ALCANÇADA/FINALIDADE APREENDIDA A PARTIR DO MATERIAL EMPÍRICO}

\begin{tabular}{lc}
\hline Sujeito & Meta a ser alcançada/finalidade \\
\hline Adolescentes & $\bullet$ Melhoria das condições de vida na favela (1) \\
& - Comportamento saudável (7) \\
& - Discussão sobre as causas dos problemas (1) \\
& - Prevenção de certas doenças e comportamento saudável (1) \\
& - Discussão para prevenção de certas doenças (1) \\
& Prevenção de uma certa doença (3) \\
\hline Adolescentes e professores & Comportamento saudável (1) \\
Pais, adolescentes e professores & Comportamento saudável (1) \\
\hline
\end{tabular}

\begin{tabular}{lc}
\hline Sujeito & Meta a ser alcançada/finalidade \\
\hline Pais, alunos, professores e funcionários & $\bullet \begin{array}{l}\text { Discussão sobre as causas das } \\
\text { doenças (2) }\end{array}$ \\
$\begin{array}{l}\text { Professores e funcionários de escolas, profissionais das } \\
\text { UBS's e do PROASE }\end{array}$ & Controle de certas doenças (1) \\
\hline
\end{tabular}

\begin{tabular}{lcl}
\hline Sujeito & Meta a ser alcançada/finalidade \\
\hline Crianças & $\bullet$ & Discussão sobre as causas das doenças (1) \\
\hline Crianças e suas mães & $\bullet$ & Discussão sobre as causas das doenças (1) \\
Crianças, pais, professores e diretor & $\bullet$ & Discussão sobre as causas das doenças (1) \\
Crianças e seus responsáveis usuários da UBS & $\bullet$ & Comportamento saudável (2) \\
\hline
\end{tabular}

\begin{tabular}{lcl}
\hline Sujeito & Meta a ser alcançada/finalidade \\
\hline Mulheres usuárias de uma UBS & $\bullet$ & Controle de uma certa doença (1) \\
Mulheres em idade reprodutiva usuárias de uma & $\bullet$ & Prevenção de uma certa doença (1) \\
UBS & & \\
Mulheres climatéricas usuárias da UBS & $\bullet$ & Comportamento saudável (1) \\
Mães com crianças em creche & $\bullet$ & Controle de uma certa doença (1) \\
\hline
\end{tabular}




\begin{tabular}{llcccc}
\hline Sujeito & \multicolumn{3}{c}{ Meta a ser alcançada/finalidade } \\
\hline Adultos & $\bullet$ & Comportamento saudável (1) \\
\hline Adultos usuários da UBS a partir de 48 anos & $\bullet$ & Controle de uma certa doença (1) \\
Adultos sadios ou portadores de doenças & $\bullet$ & Controle de $\quad$ certas doenças e \\
crônicas & & & comportamento saudável (1) \\
\hline
\end{tabular}

\begin{tabular}{llll}
\hline Sujeito & Meta a ser alcançada/finalidade & \\
\hline População em geral & $\bullet$ & Discussão sobre as causas das doenças (1) \\
& $\bullet$ & Melhoria das condições de vida no \\
& município (1) & Melhoria das condições de vida no bairro \\
& $\bullet$ & $(1)$ \\
\hline População rural assentada & $\bullet$ & Melhoria das condições de vida no \\
& $\bullet$ & assentamento (1) \\
\hline População semi-rural e trabalhadores de uma & $\bullet$ & Comportamento saudável (1) \\
creche & & \\
\hline Transeuntes & $\bullet$ & Comportamento saudável (1) \\
\hline Ouvintes de uma rádio e leitores de um jornal & $\bullet$ & Causas dos problemas de saúde (1) \\
Ouvintes da rádio universitária & $\bullet$ & Melhoria das condições de vida em casa e \\
& & prevenção de certas doenças (1) \\
\hline
\end{tabular}

\begin{tabular}{lcl}
\hline Sujeito & Meta a ser alcançada/finalidade \\
\hline Bancários & $\bullet$ & Melhoria das condições de trabalho (1) \\
Funcionários de uma universidade pública & $\bullet$ & Prevenção de certas doenças (1) \\
Agentes locais de saúde & $\bullet$ & Prevenção de certas doenças (1) \\
Conselheiros locais de saúde & $\bullet$ & Discussão sobre as causas dos problemas \\
& & de saúde (1) \\
\hline Educadoras infantis & $\bullet$ & Comportamento saudável (1) \\
& $\bullet$ & Prevenção de certas doenças (1) \\
\hline
\end{tabular}

